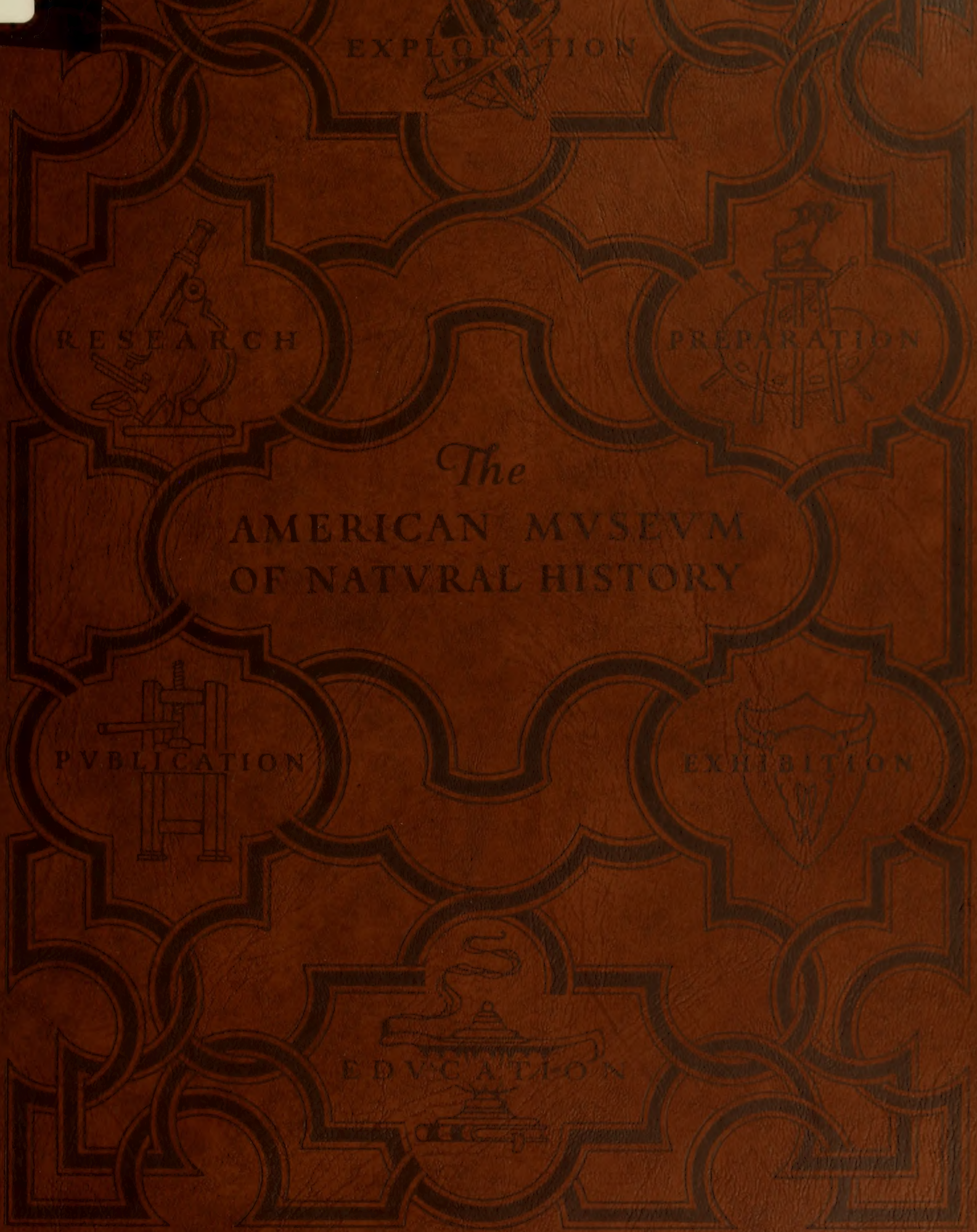




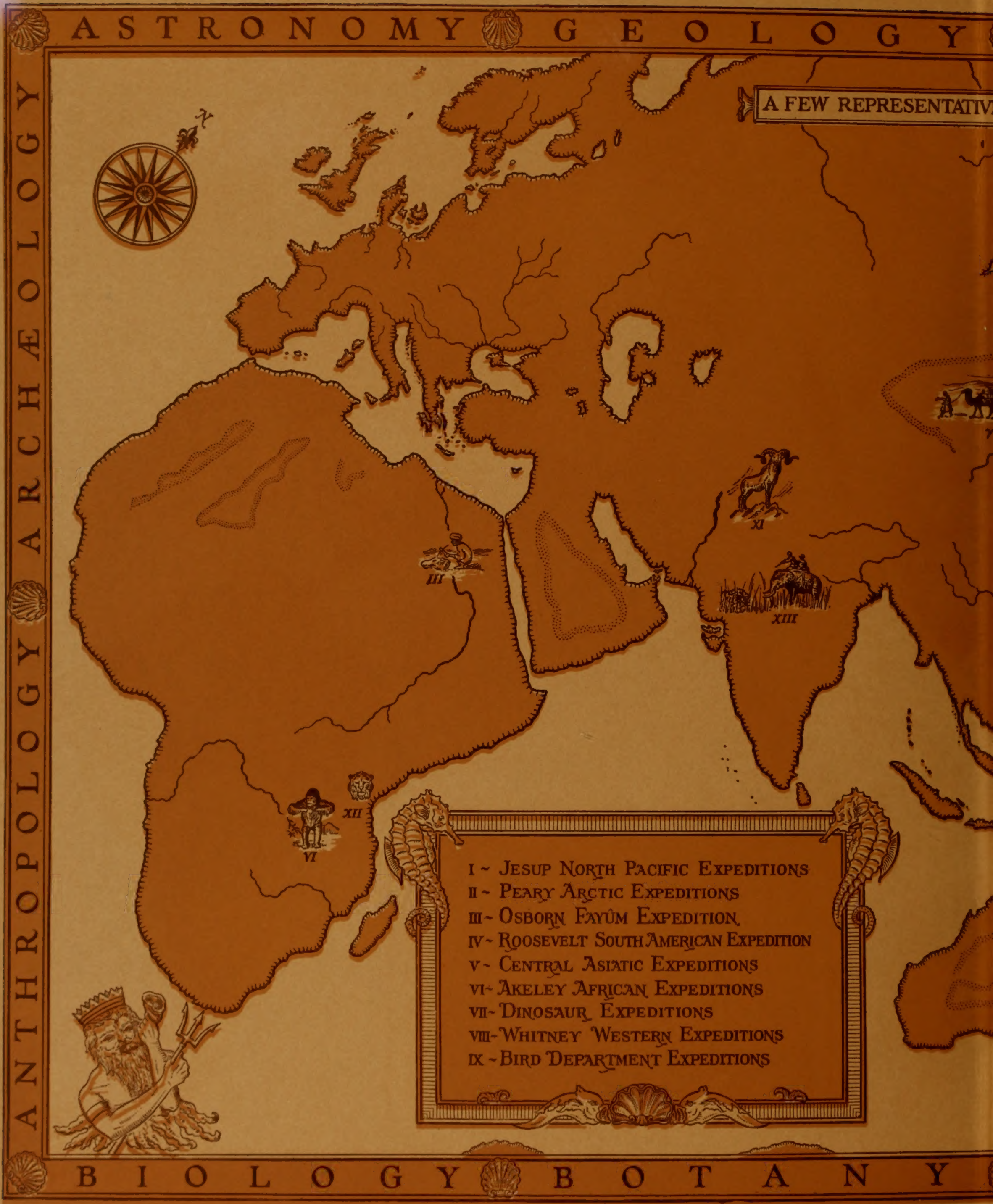




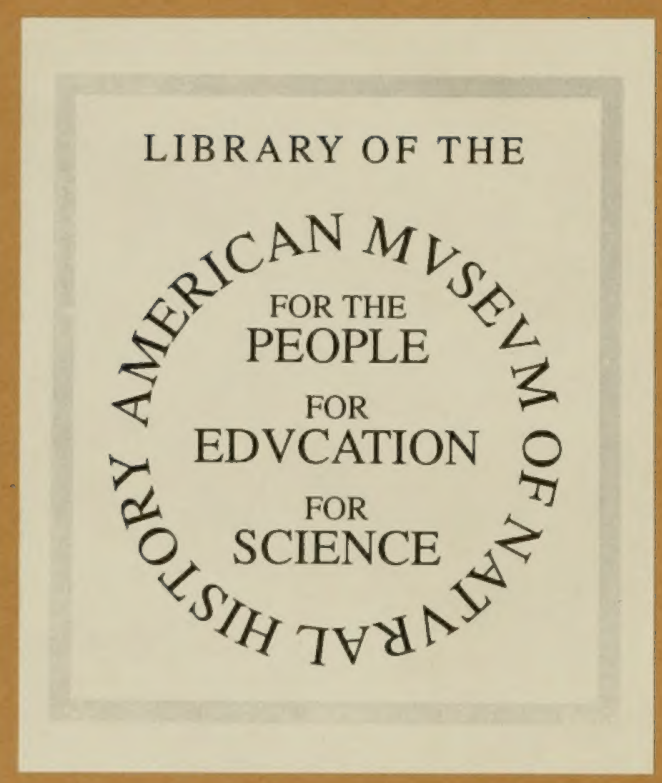





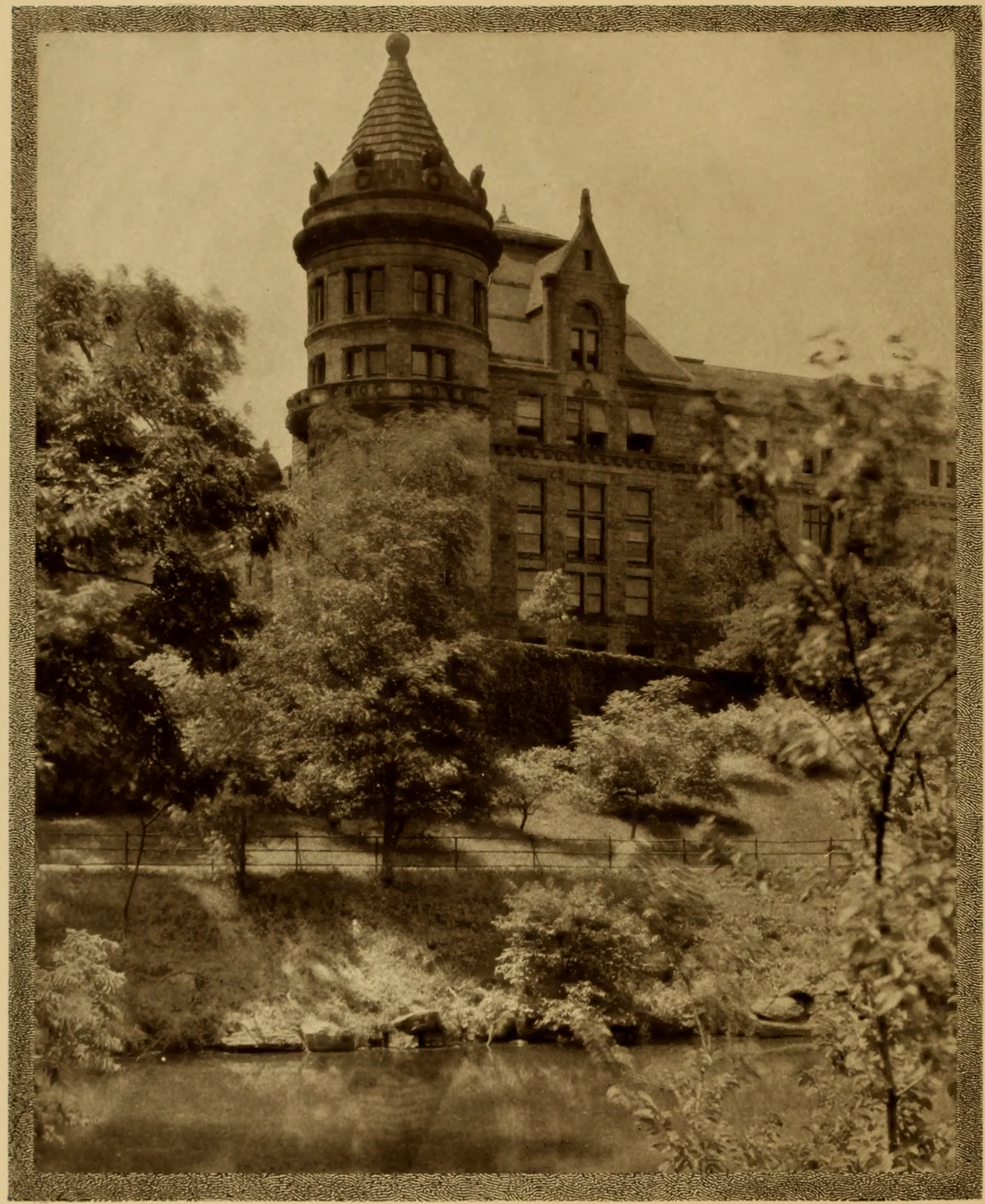

A Modern Citadel of Science

A Glimpse of the American Museum of Natural History from Central Park 


\section{The American Museum of Natural History}

An Interpretation

Published by the Museum

MCMXXXI NEW YORK 
THIS brochure, a Museum product, has been made possible by the joint labors of American Museum officials, scientists, artists, photographers and printers.

no

Text by a Member of the Museum

Art work by the Department of Preparation

Illustrations by the Photographic Division of the Department of Education

Printing by the Museum Press 


\section{BED ROCK}

$A^{N}$

INSTITUTION which rests squarely upon basic schist one billion years old may with truth claim to be a bed-rock establishment. On such a physical base, as in the case of the Biblical wise man, the American Museum of Natural History has built its house of granite, buttressing this great structure of the 'Seventies by successive additions until the floor space will soon aggregate twenty-two acres.

On a rock-like base, too, has been erected its scientific work; now, in America's chief city, the Museum stands as one of the world's great repositories of human knowl. edge concerning our planet -its origin, structure and place in our universe; flora and fauna, past and present; races of men.

Into every life zone of the globe, into every recess of history and pre-history the Museum has projected its searching till half a hundred exhibition halls are not enough to hold its collections, nor two hundred-odd study rooms and laboratories to care for its research material. Yet the work which the world has come to expect of it is barely begun.

Like a shifting kaleidoscope that vast work constantly makes new patterns. The astronomical department is found observing island universes thousands of light years away; a staff geologist records earth tremors felt in the Philippines, while indefatigable fossil hunters, home from Patagonia, or Africa, or Alaska, ferry across the Hudson to ex. hume from under the Palisades the skeleton of some phytosaur buried for a hundred and fifty million years. . . .

Great exploring parties leave for the Gobi desert, for Greenland, for the Ant. arctic Circlewhile a one man expedition crosses the street to count the species of southward bound migrants that pause overnight in Central Park ... Not far away in a New Jersey backyard the curator of entomology is collecting insects after hours for $\mathrm{Mu}$ seum cases-eight hundred and thirty-six species caught in one backyard. . . . . 


\section{BED ROCK}

This continent has, as is known, an edge, a shelf, a jumping off place into very deep water indeed-twelve to thirty-five thousand feet. On the slopes of that black abyss inhabited by finny, phosphorescent grotesques, a Museum ichthyologist, not sixty miles from his laboratory, trawls for specimens. ... In the $\mathrm{Ba}$ hamas a curator, from a submarine tube, directs the removal by divers of forty tons of submerged coral reef to make a replica for an undersea exhibit. ... .

Within Museum walls, research parallels or transcends the work of discovery in the field. Experiment, for example with some of the unknown resources of endocrinology, upon salamanders as subjects, has already shed much light upon the chemical messengers of the body which control the reproductive cycles of higher animals, including man. . . .

Everywhere about this great institution - in field and research laboratory, exhibition hall and preparation workrooms - are the visible evidences of that restless, inquiring spirit of man which forever must be investigating the heavens above and the earth beneath and the waters under the earth, and still find new miracles to surpass the old. . . Here is kept as nearly complete a three-dimensional diary of our own evolution as may be found anywhere.

It is of importance to all of us that there be no lapses in this fundamental record - that the hands of those keeping it be upheld and enough other hands be procured to make every needed entry.

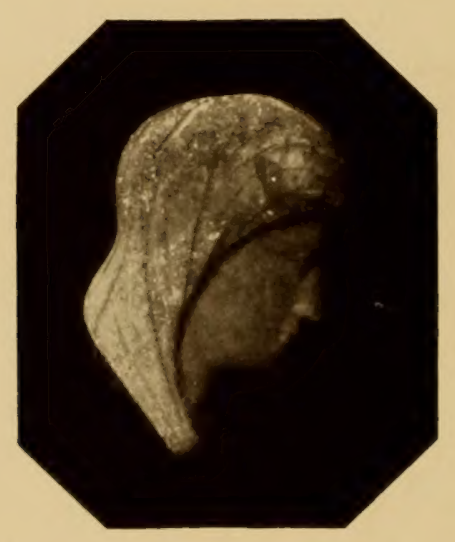




\section{ORACLES}

$\mathrm{T}^{\mathrm{H}}$

HE FIRST museum was Greek; the name means Temple of the Muses. As greatly revered as those temples of knowledge, some founded by Aristotle under the patronage of Alexander, were those other Grecian shrines, the Oracles, the most famous - the Cave of Delphi-being the traditional mouthpiece of the Earth Goddess herself before it was claimed for Apollo.

The modern museum is both temple and oracle, or mouthpiece of earthly wisdom.

As Temple:

The American Museum was visited last year by a million votaries; over two hundred thousand attended its public lectures and motion pictures; fifteen hundred its cultural courses for teachers. More than six hundred schools of Greater New York sent classes and teachers here for study and received nature collections, slides, films; the educational contacts made with a million school children reached

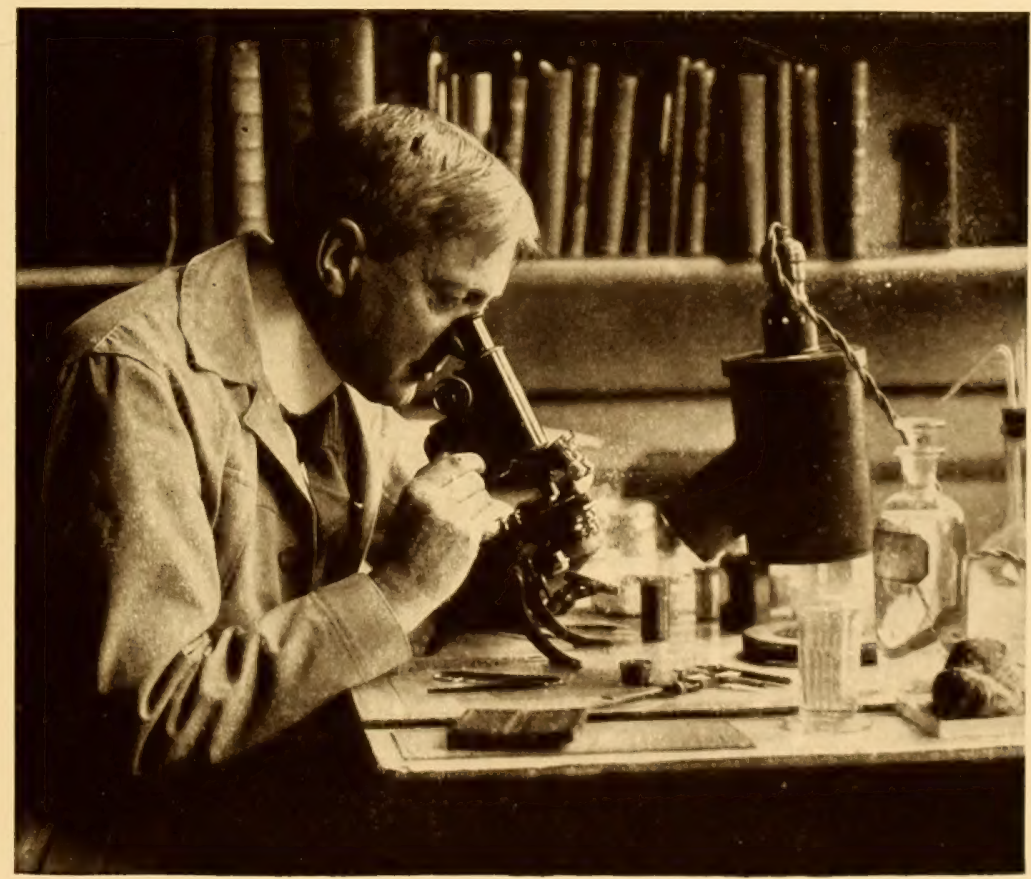

the amazing total of twelve and a half million! In addition, nineteen universities, colleges and art schools used the Museum as an extension field for the work of undergraduate and graduate students.

This institution is headquarters and meeting place for twenty-four scientific societies, six of them national; it is either headquarters or a center for the conventions, exhibitions and field study of twenty-seven other associations representing American education, arts and industries. Such varied and specialized groups as photographers, jewelers, engineers, lumbermen, horticulturists, fishermen, conservationists, and classes of the blind and deaf frequent this Museum en masse. 


\section{ORACLES}

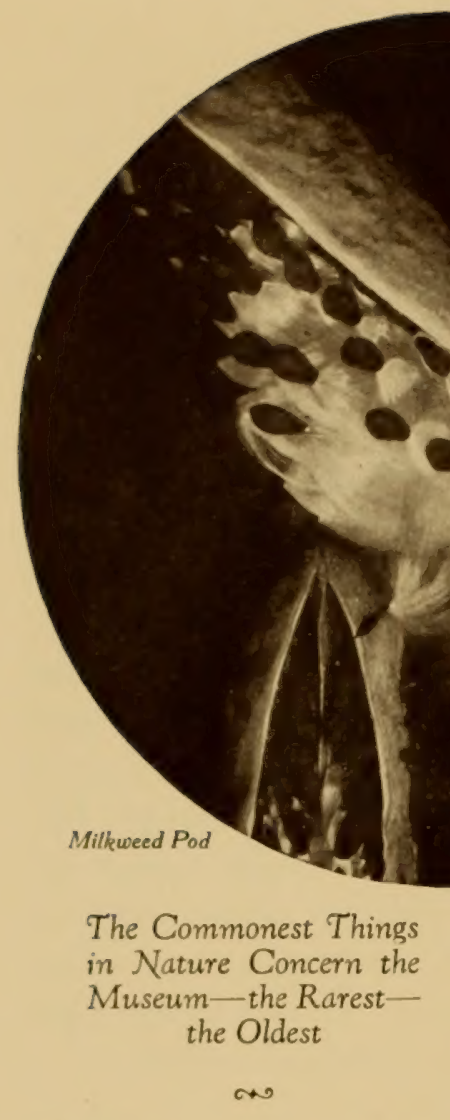

For example:

An eminent palaeontologist would like a de. tailed report on the depths of the submerged land connections between five Mediterranean islands and the mainland.

The Rockefeller Foundation wants all ex. tant data on fish as exterminators of mos quito larvae to use as a handbook for doctors and field men in tropical countries.

Representatives of the Tanners' Council and of the United States Treasury Department respectively call upon the curator of mammals to ascertain the exact meaning of the words "bovine species" in a proposed tariff bill, since upon their definition would hang the levy of heavy duties on hides about which a contest might arise.

A cancer specialist requests a dozen specimens of lead ores of differing geologic ages and degrees of radioactivity. The specimens are secured for him from mines in Burma, India, Alaska, Canada, and the United States. Edison, at his request, breaks down the selected sample in colloidal solution, which now forms the basis for cancer treatment in a Long Island hospital. . . . . To consult the Museum's current index continuing Bash. ford Dean's unique bib. liography of fishes, a professor of pathology journeys from the mid. west, where tapeworm is on the increase in three states due to the habitual

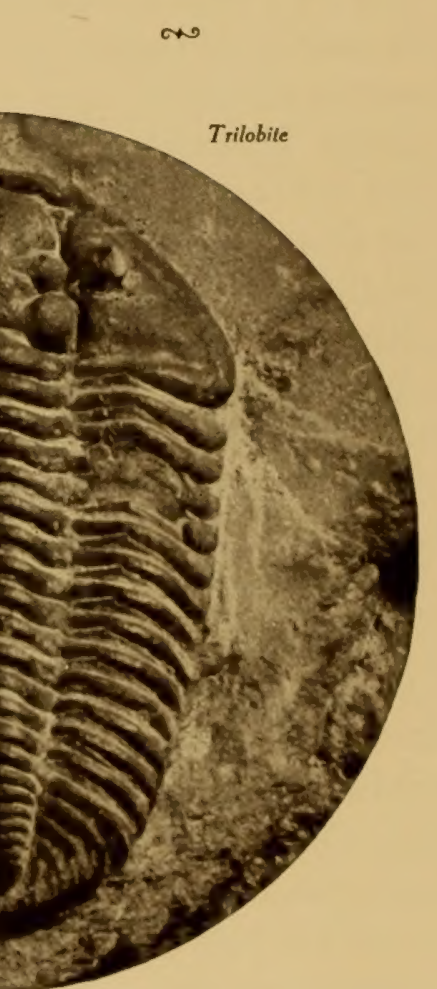




\section{ORACLES}

consumption of infected raw fish by the Baltic immigrant population.... A chemist in search of new sources of insulin inquires where sharks are being killed in such quantity that their insulin producing organs may be readily obtained. . . . In the department of comparative anatomy - affiliated with Columbia University proper and with its College of Physicians and Surgeons - neurologists, dentists, and orthopaedists pursue researches into the evolution of body structures from lower animals to man, and one university orthopaedist, after a long and detailed examination of the feet of primates, is enabled to make a successful device to correct improper balance in the human foot. . . .
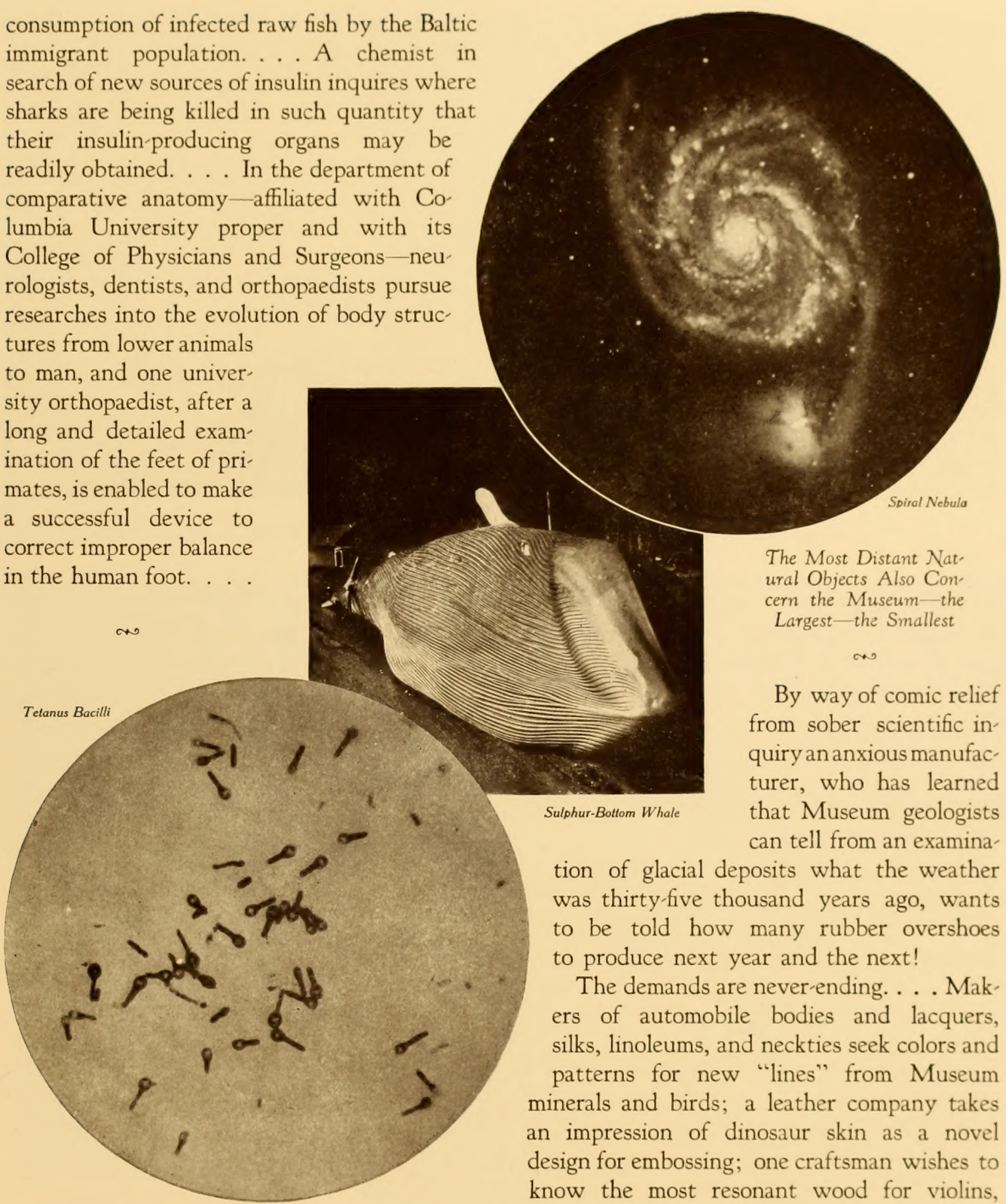

By way of comic relief from sober scientific in. quiry an anxious manufac turer, who has learned that Museum geologists can tell from an examinaSulphur-Bottom Whal tion of glacial deposits what the weather was thirty-five thousand years ago, wants to be told how many rubber overshoes to produce next year and the next!

The demands are never-ending. . . Makers of automobile bodies and lacquers, silks, linoleums, and neckties seek colors and patterns for new "lines" from Museum minerals and birds; a leather company takes an impression of dinosaur skin as a novel design for embossing; one craftsman wishes to know the most resonant wood for violins, 


\section{ORACLES}

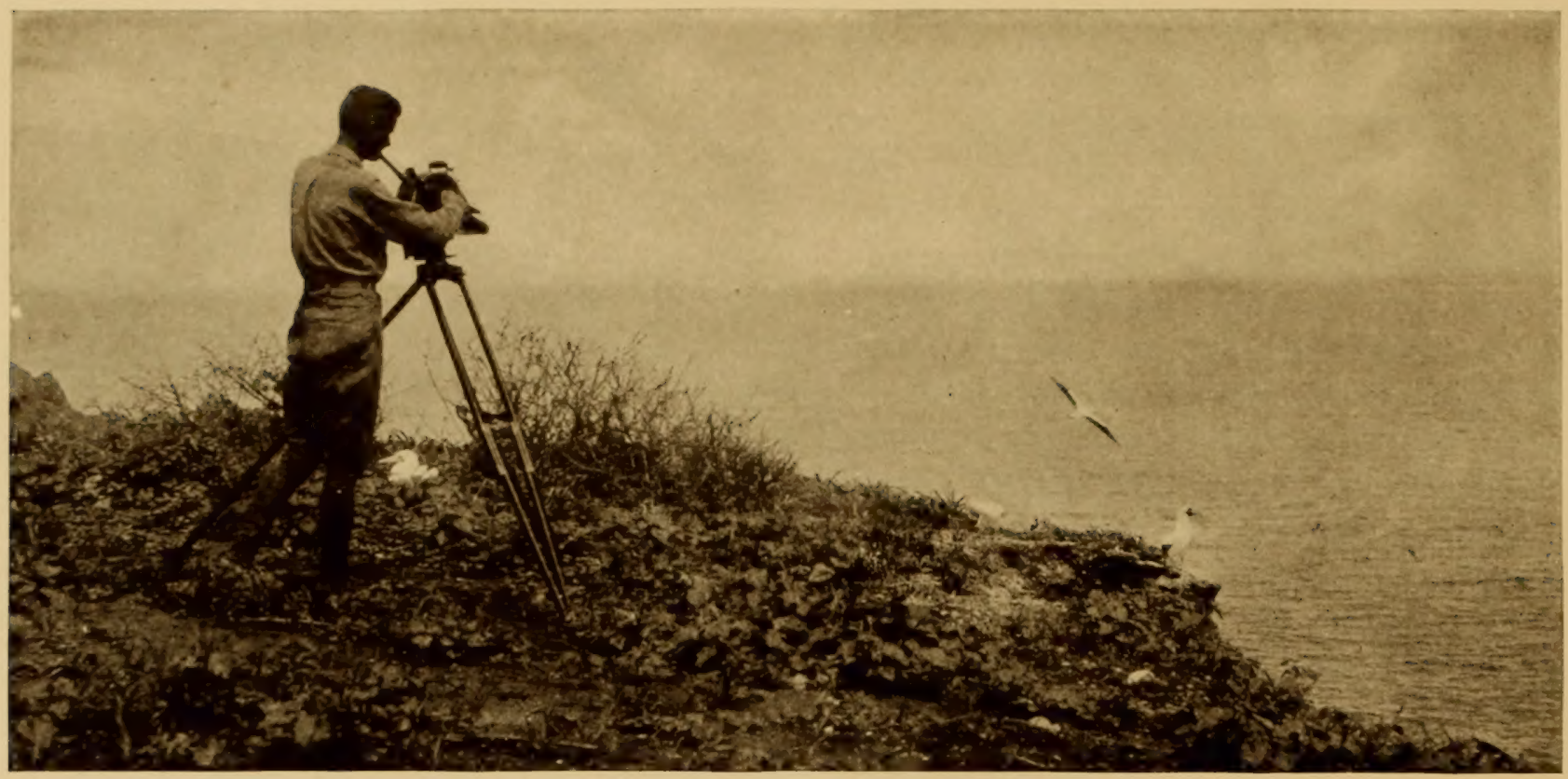

No Place is Too Inaccessible for the Museum CuratorVisiting Remote Bird Islands

another the most silent for silent typewriters. Pathé devises a film to display the famous jewels of the Morgan collection, and the producers of "The Lost World" model from Museum reconstructions, on a scale of inches, live-appearing dinosaurs.

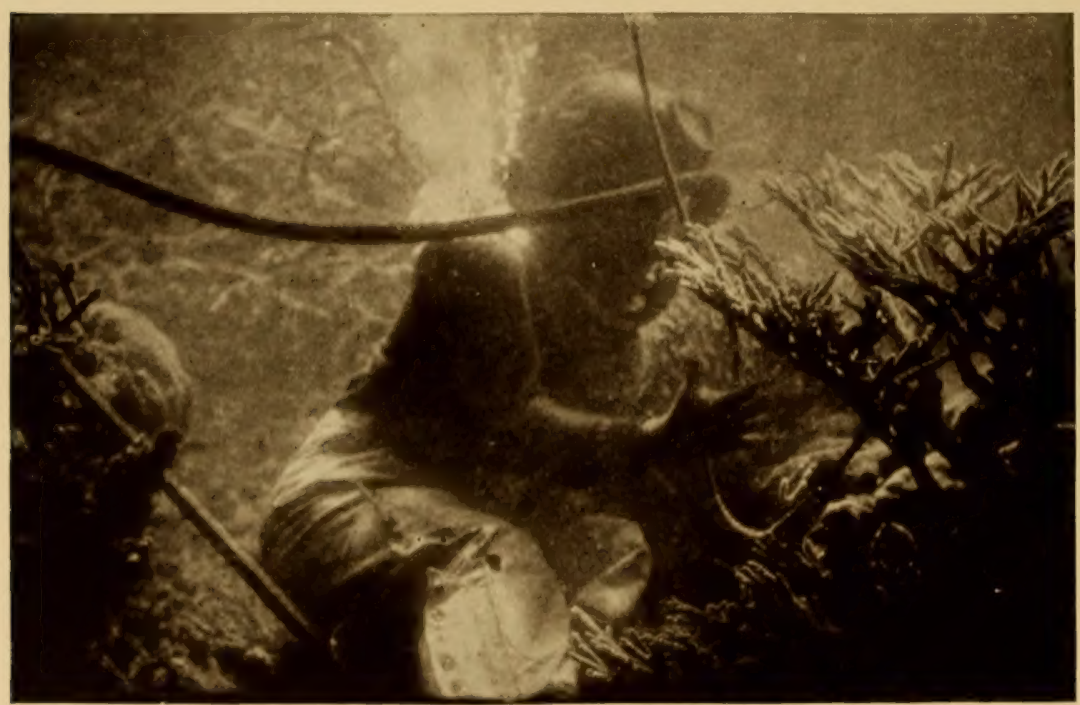

Industry and government frequently make major requisitions upon the Museum's fund of knowledge. Explorers and research authorities are called into consultation on questions of legislation, finance, trade and immigration, development of new territory, and conservation.

Banking houses contemplating loans apply for information as to the resources of foreign countries; customs and immigration officials appeal for testimony in moot cases.... An American construction company, required by the King of Abyssinia to build four hundred miles of difficult road for the transportation of materials for a new dam across the Blue Nile,

Collecting Corals Undersea

Page Ten to 


\section{ORACLES}

Descending into Caves to Hunt for Blind Salamanders

$$
\infty
$$

confers at length with a curator who has hunted for fossils all through the region. From him are obtained the facts upon which to base an estimate of the road's cost and potential revenue from tolls. Another corporation entreats his advice before floating a bond issue for a similar African highway to tap an area of mineral wealth. . . .

As is generally known, oil

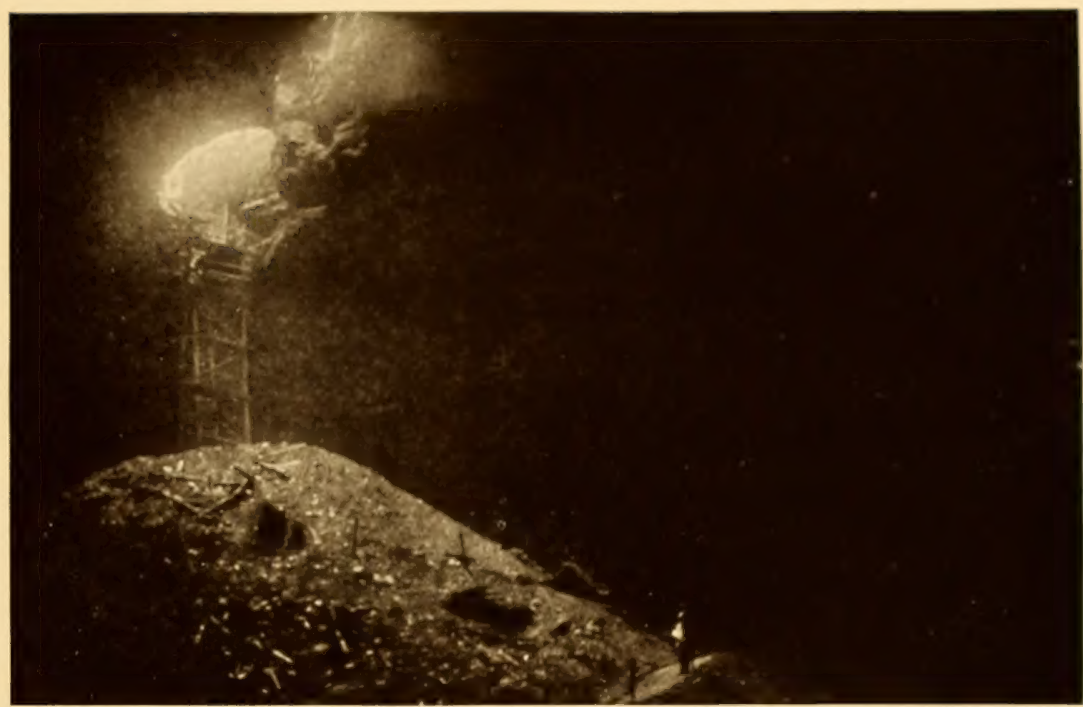
and mining companies lean heavily upon geologists for data as to the age and formation of the rocks in which they propose to operate. While

the basis of the Museum's work is pure science, its conclusions are appropriated by industry and applied science.

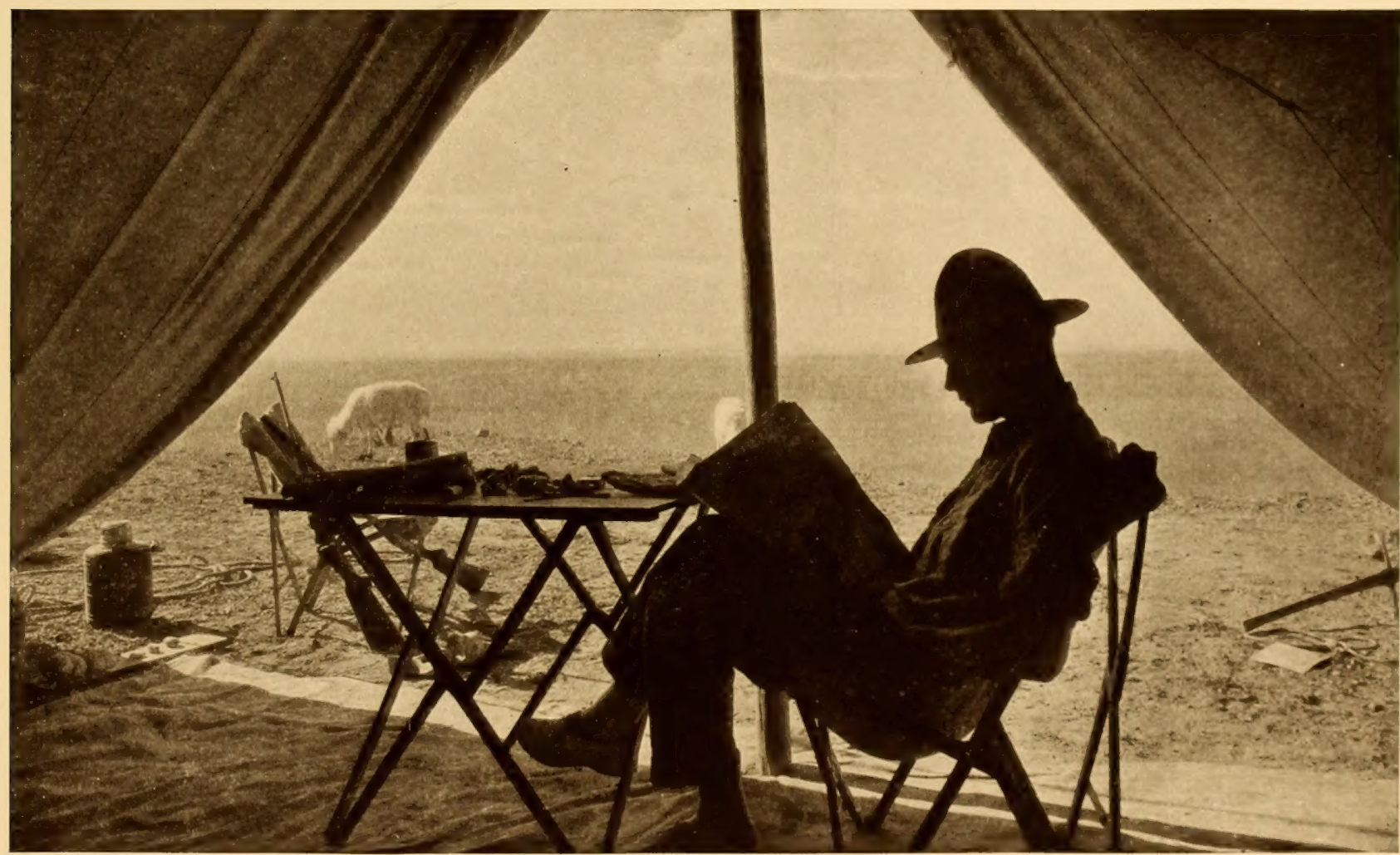

At Home in the Desert 


\section{ORACLES}

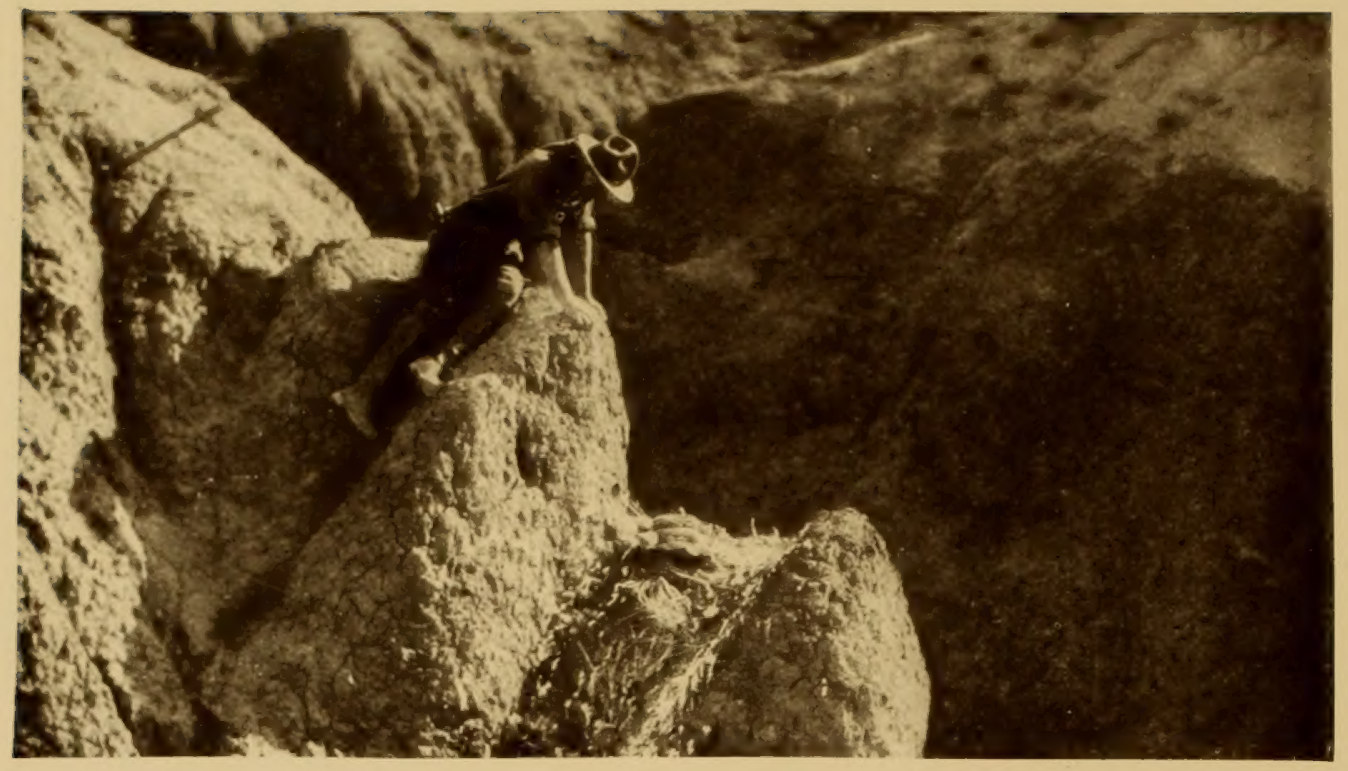

Above:

The Museum

Curator Climbs

to an Eagle's Nest

No

Below:

Digging for Lizard

Eggs in the Tropics

In the great field of conservation of natural resources, worldwide recognition has been accorded American Museum men for their distinguished contributions to this cause. When King Albert of Belgium sets aside a half million mountainous acres in the Belgian Congo as a sanctuary for the maligned and fast-disappearing gorilla, the public does not need to be reminded that this is a culmination of the labors of Carl Akeley. ... When the Roosevelt medal is awarded one year to Hughes, Lindbergh, and that friend and adviser of Roosevelt, the Museum's chief ornithologist, the newspapers comment that he has done more than any other American to waken the country to an appreciation of its bird life and to bring about protective legislation.... To do as much for the animal life of the world the American $\mathrm{Mu}$ -

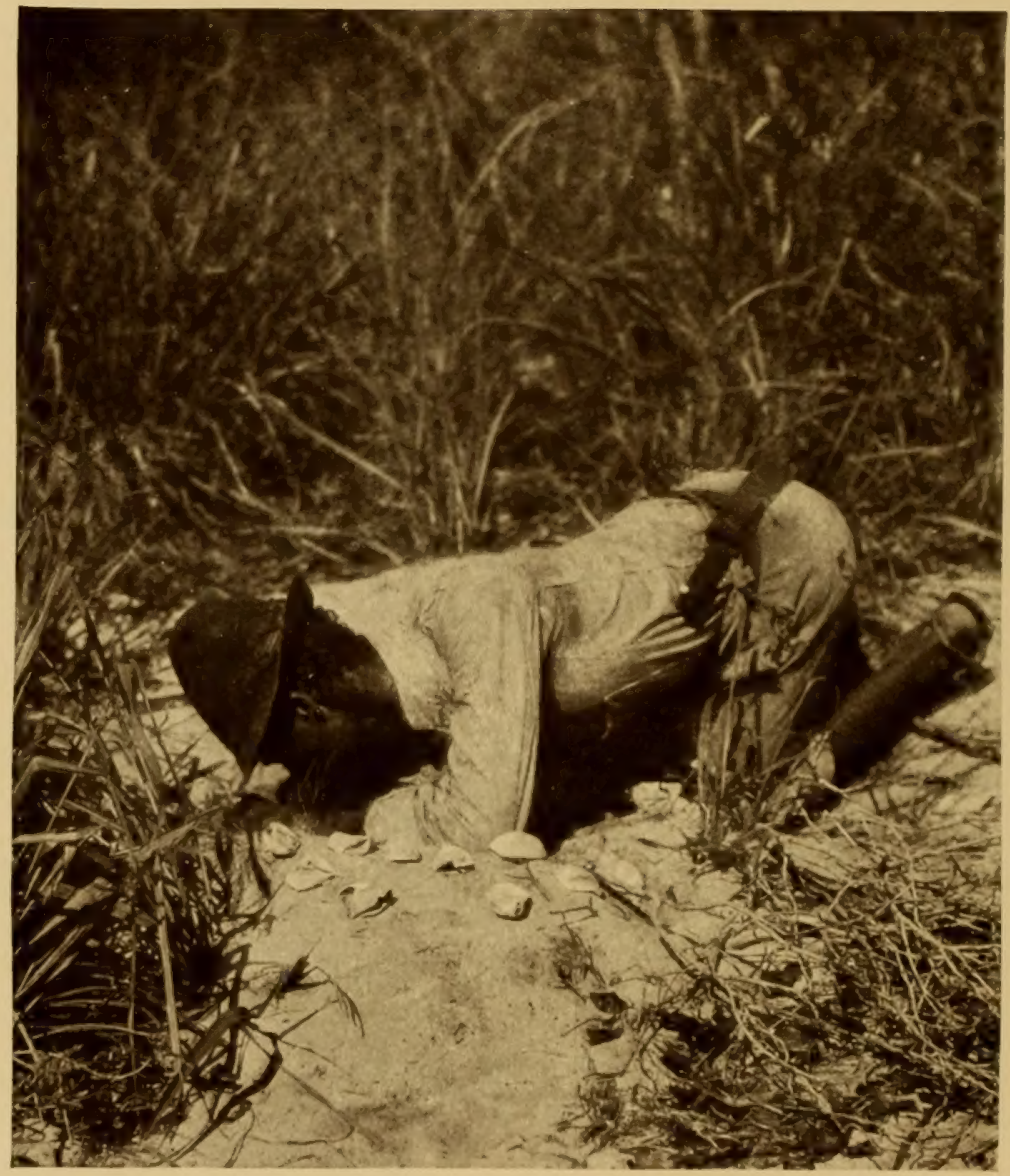




\section{ORACLES}

Above:

Reconnoitering from Tree Tops in the South Seas

Below:
Uncovering Fossils
in the Gobi
ow
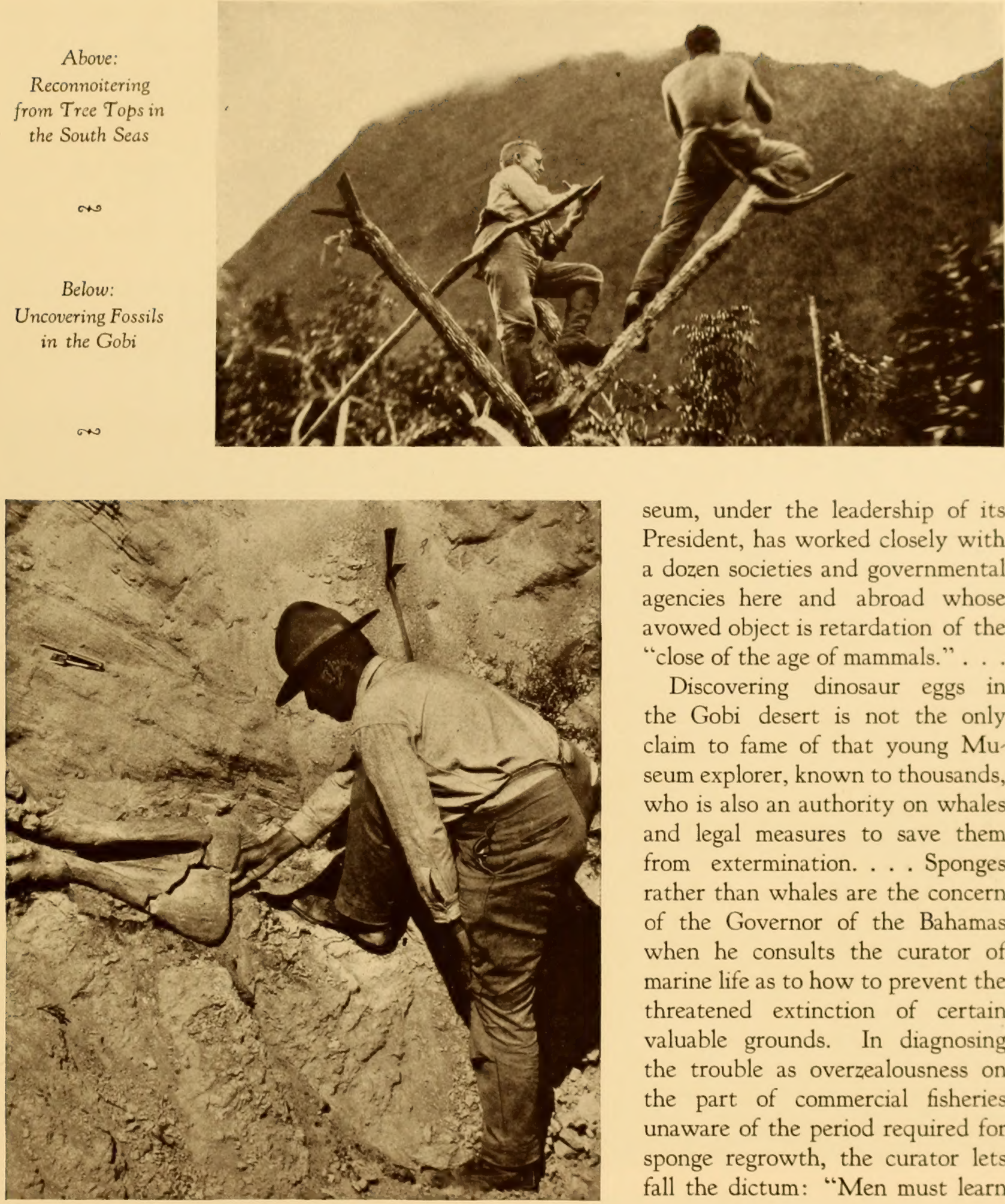

seum, under the leadership of its President, has worked closely with a dozen societies and governmental agencies here and abroad whose avowed object is retardation of the "close of the age of mammals." . . .

Discovering dinosaur eggs in the Gobi desert is not the only claim to fame of that young $\mathrm{Mu}$ seum explorer, known to thousands, who is also an authority on whales and legal measures to save them from extermination. ... Sponges rather than whales are the concern of the Governor of the Bahamas when he consults the curator of marine life as to how to prevent the threatened extinction of certain valuable grounds. In diagnosing the trouble as overzealousness on the part of commercial fisheries unaware of the period required for sponge regrowth, the curator lets fall the dictum: "Men must learn 


\section{ORACLES}

not to be spongers on the rest of the animal kingdom." . . .

Oracles all, these scientists whose salaries are fifty per cent. lower than those of college professors of similar calibre-whose departments are undermanned and underfinancedwhose time for the research that makes them of value to science and to the world of affairs is cut to shreds not only by routine labors which should be delegated but by the necessity for serving as general information bureaus. ... If there were more assistants, both detail men to relieve an executive and teaching curators to take charge of the exhibition halls and lectures - then he might have more freedom for study and investigation in his field of science.

But meantime, on the heaped-up pile of his daily duties, the questions fall, thick and fast, till every department in the Museum is buried by them:

"Acting on the advice of Professor Julian Huxley, I am instructed to invite you to write for the Biology and Zoology sections in the

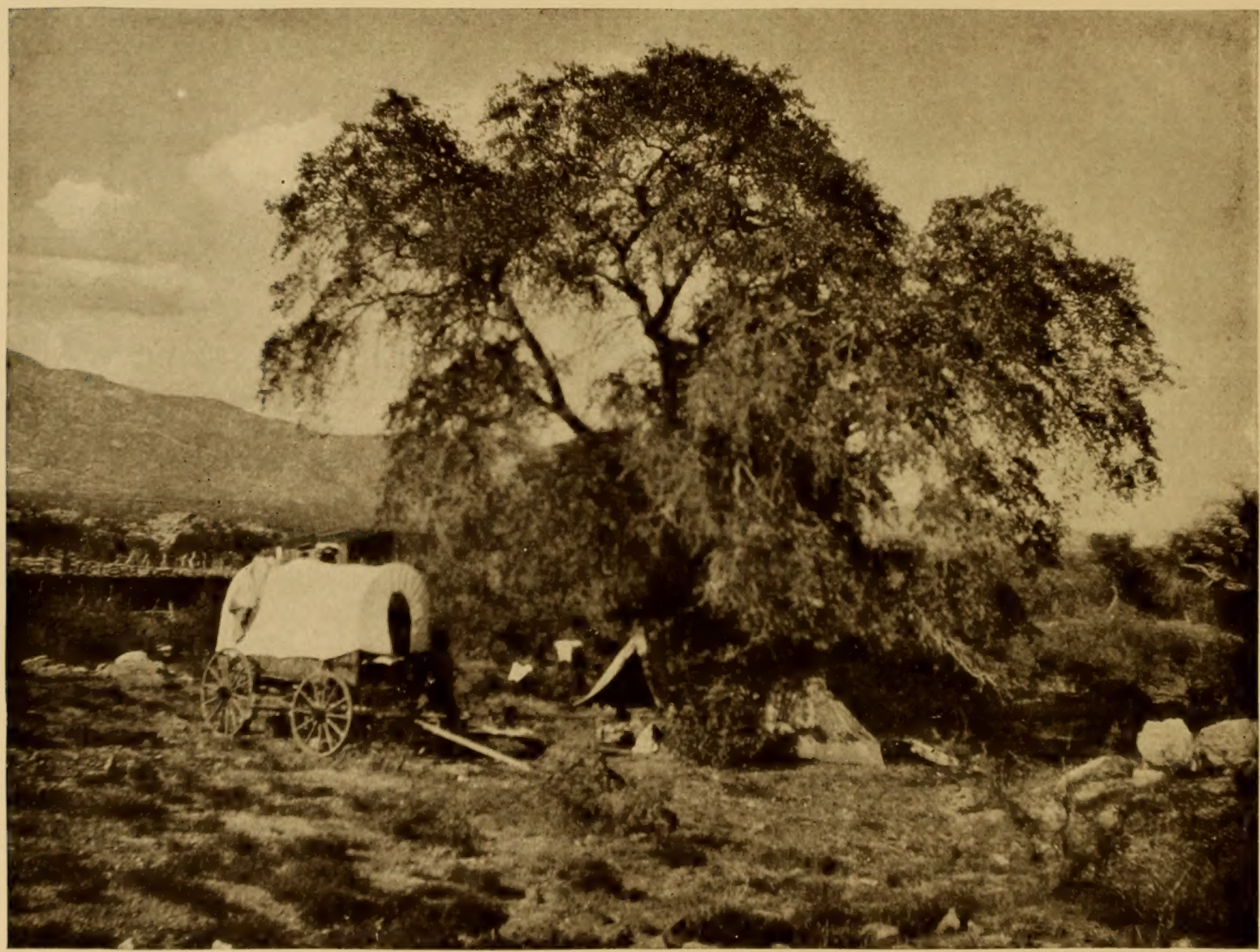

Like the Pioneers, the Museum Curator Crosses Western Deserts by Wagon-in Search of Insects 


\section{ORACLES}

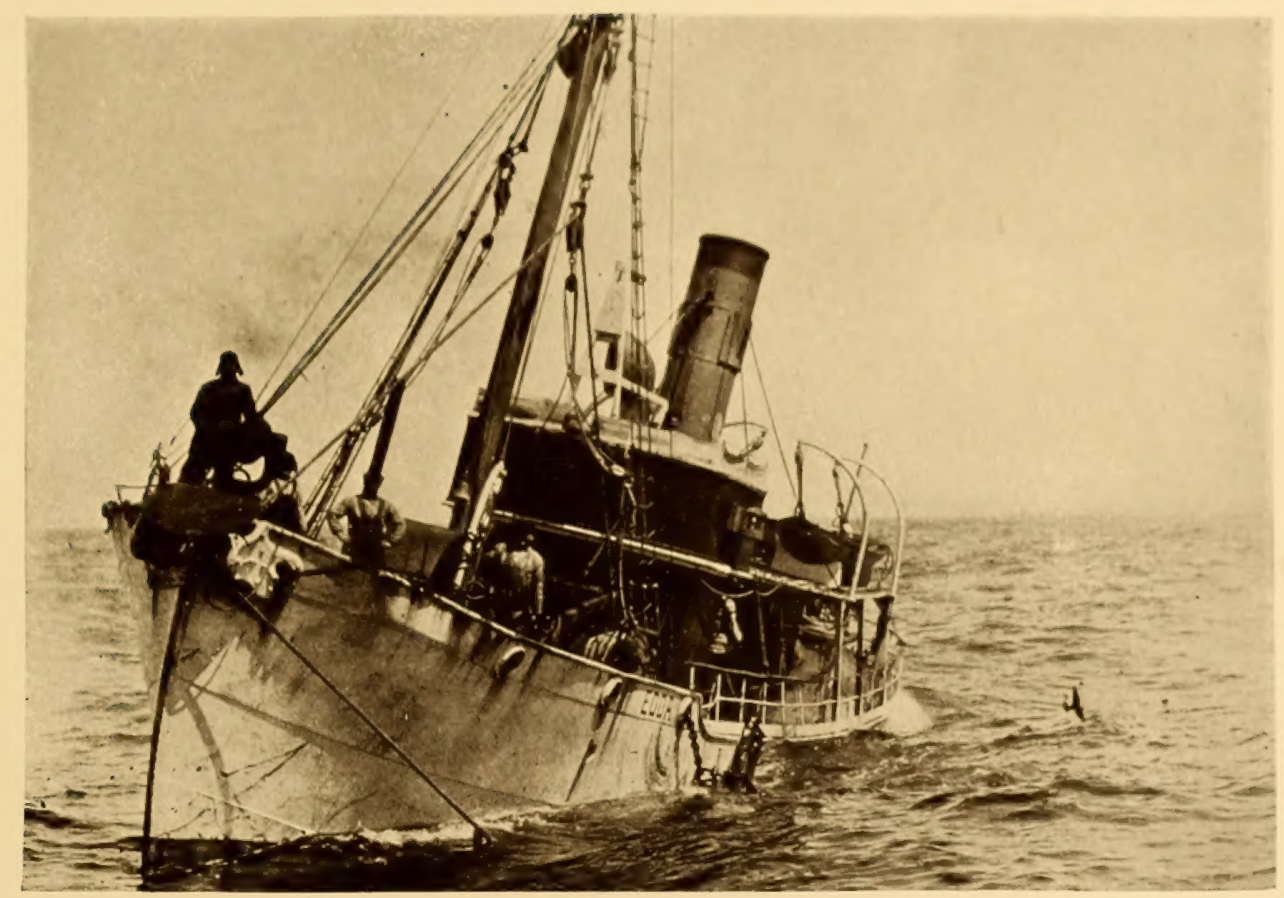

Aboard a "Whale Chaser" in the Antarctic

new edition of the Encyclopaedia Britannica the articles in the enclosed list"-(42 titles, with a space allotment of 116 columns totalling more than 80,000 words).

"Kindly tell, just in a word or two (!) what kind of rock forms the foundation for New York City, what fossils are found in it, are there any faults and what is its geologic age?"

"Will you participate in a round-table discussion on abatement of the smoke evil in our cities, with particular reference to the effect upon the health of the inhabitants through the loss of the beneficial ultra-violet rays?"
"Have you in your Library a picture of $\mathrm{Pal}$ estine with definite kinds of cattle grazing?"

"As a retired professional man, I am thinking of taking up entomology as a pursuit. Will you be good enough to advise me how to begin?"

"Please suggest thirty-five Indian names with appropriate meanings for orders of merit for boys and girls winning woodcraft and Nature study badges."

"Our State [California] Game and Fish Commission is preparing a bibliography on the tuna fish. . . May we send a representative for six weeks' work under your bibliographer of fishes?" Et cetera, et cetera. 


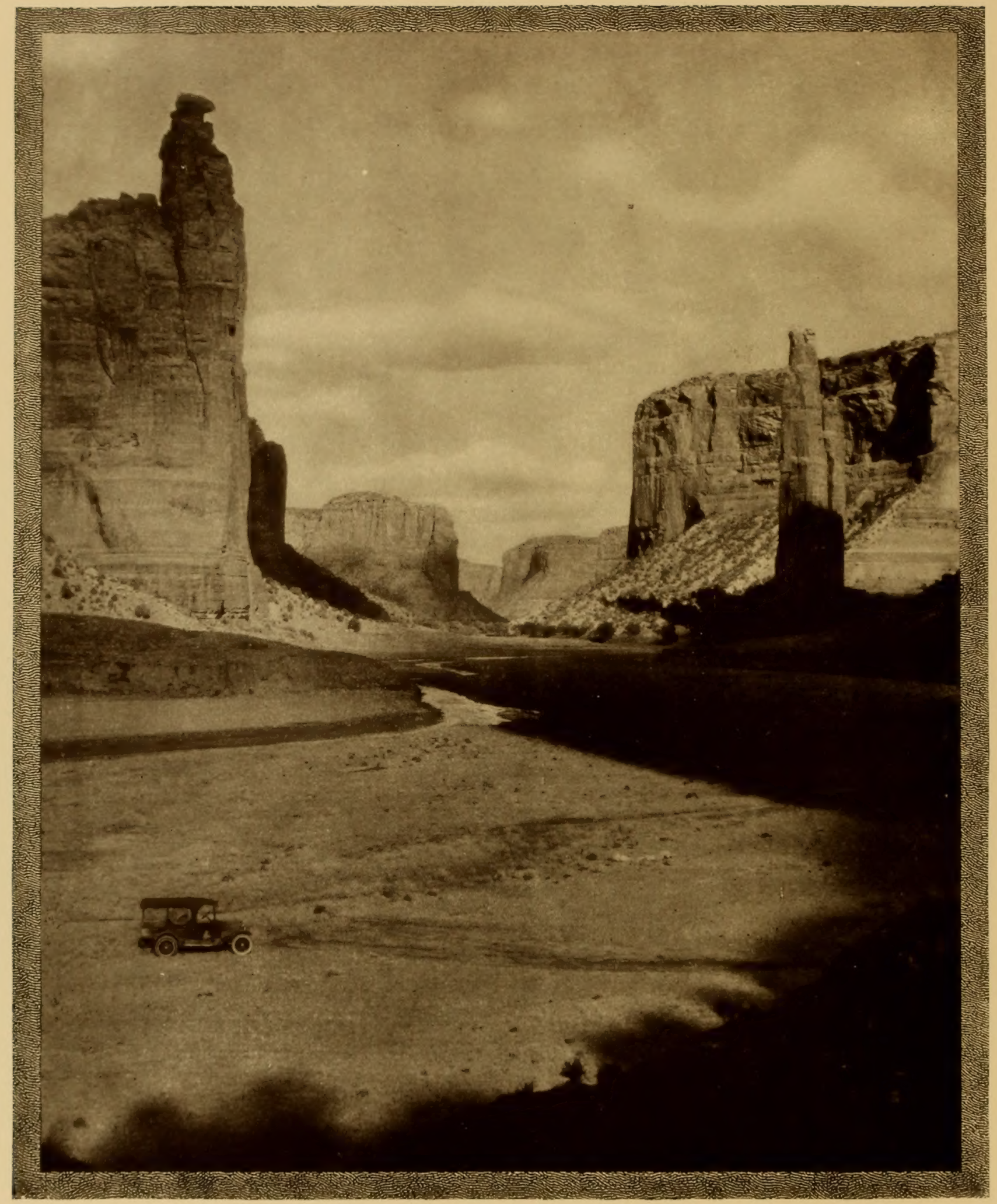

A Gateway to an Archaeologist's Paradise-the Buried Past of Our Own Southwest 


\section{EXPLORATION}

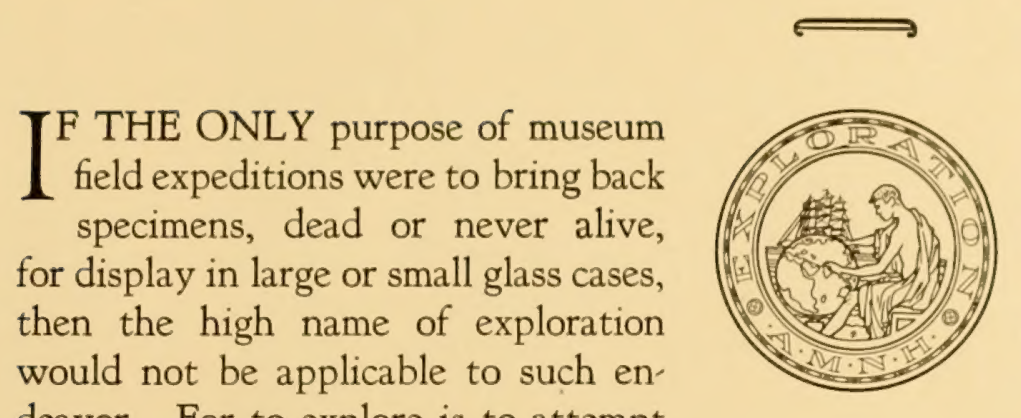

be financed-which constitutes the rub. . . .

Many expeditions go out from the American Museum of Natural History - there have been as many as sixty, large and small, in the field in one year. Some, because of more to discover something previously unknown, whether it be a new species of animal, living or fossilized, or new facts about the life and works of so familiar a friend as the red squirrelwhether it concern the racial origins of the American Indian or of the bird forms of the High Andes and South Seas. To poke in to the far corners of the earth may be adventure, but only when one finds out exactly what is in those corners and why, and what is or has been its be. havior, significance and relation to other forms - only

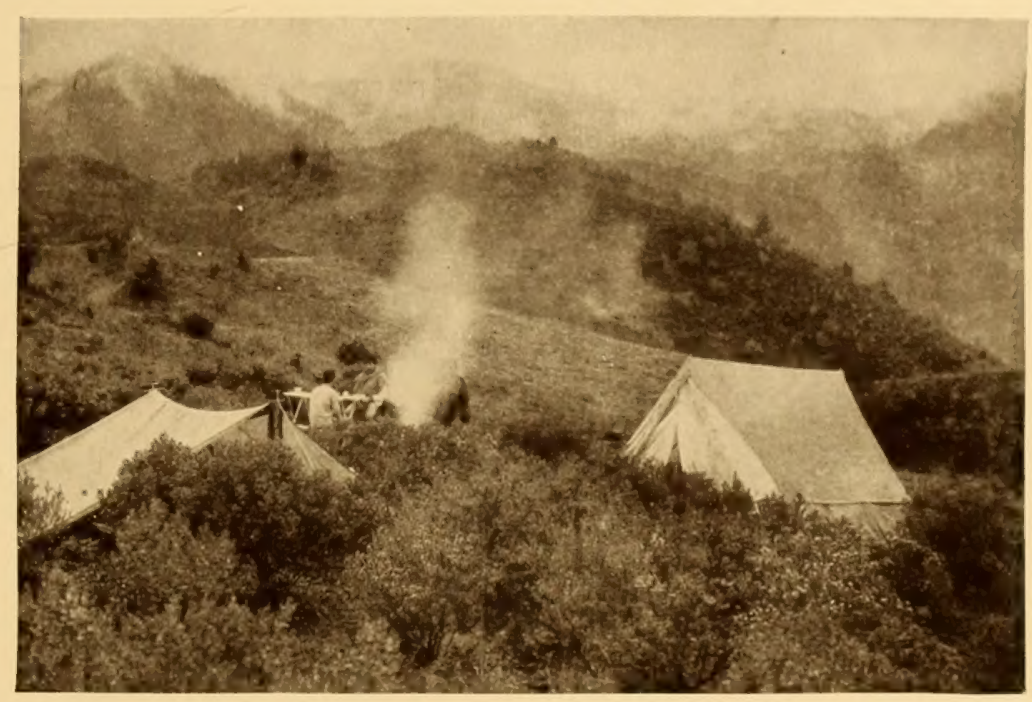

Encamped, Mile High, to Study Bird Life on Mount Orizaba ample, long time outside financing, have been able to complete units in comprehensive programs extending over years and attacking fundamental regional problems from all the scientific angles represented by various specialists on the field staffs. . . O Others, and these the majority, do no less thorough and valuable work while about it, but must do it piecemeal, as opportunity-i.e. money - offers; a bit here and a bit there, out of sequence. Department ex ploration becomes sporadic and explorers opportunists.

then does adventure become exploration.

This, be it noted, implies a programit is like city planning in that the units undertaken from time to time contribute to a total result - must answer some broad, general queries. Programs, however, must
This is the situation when there is no adequate, stabilizing museum fund for exploration, so that recourse must be had to occasional outside gifts which almost invariably are restricted to some specific venture.

The importance of planned, programmed, 


\section{EXPLORATION}

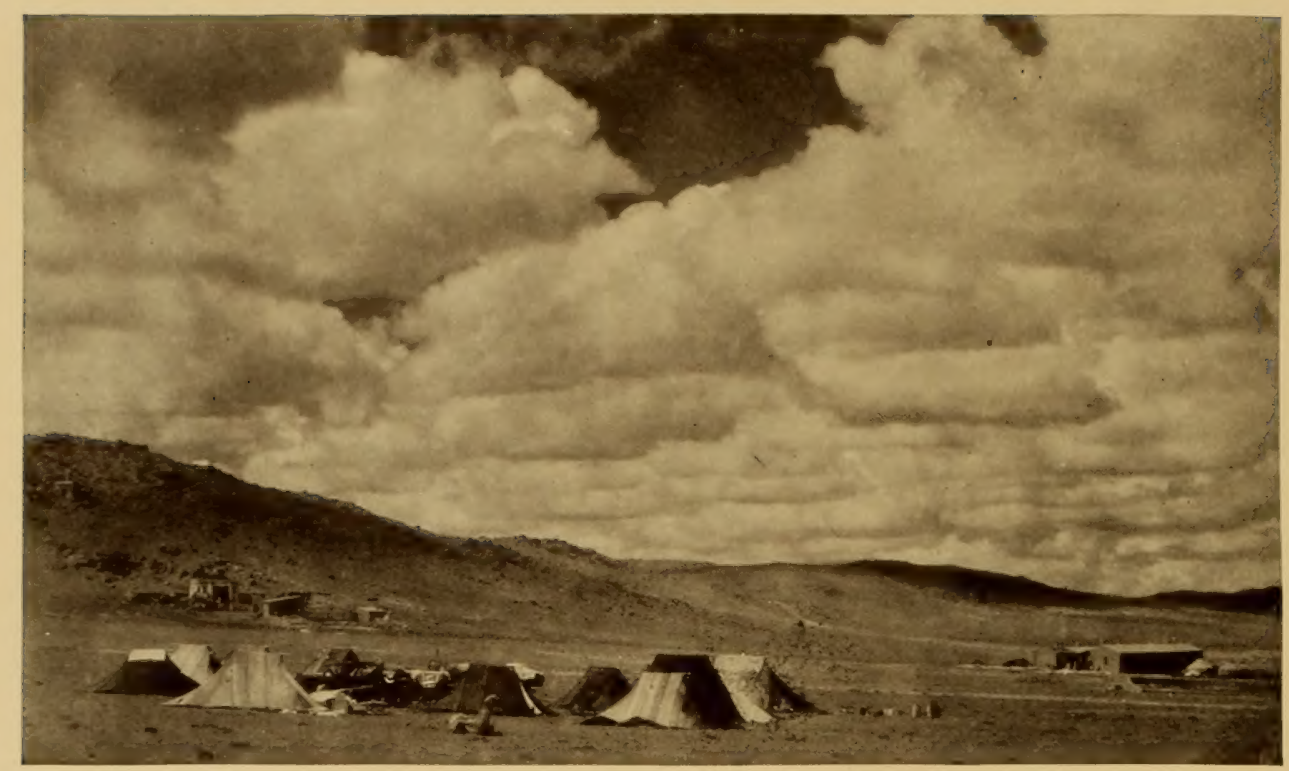

The Central Asiatic Expedition in the Gobi Desert of Mongolia

comprehensive projects has no weightier exemplar in American Museum history than the great Jesup North Pacific Expeditions of 1897 to 1903 , which studied the coastal tribes of northwestern Ameri$\mathrm{ca}$ and northeastern Asia, endeavoring to determine the connections, racial, cultural and historical, between Asia and the New World. More as by-products than as end results of the work of a distinguished staff and group of American and Siberian collaborators, huge collections filling several halls were amassed. The research conclusions of the staff were pub. lished in ten volumes.

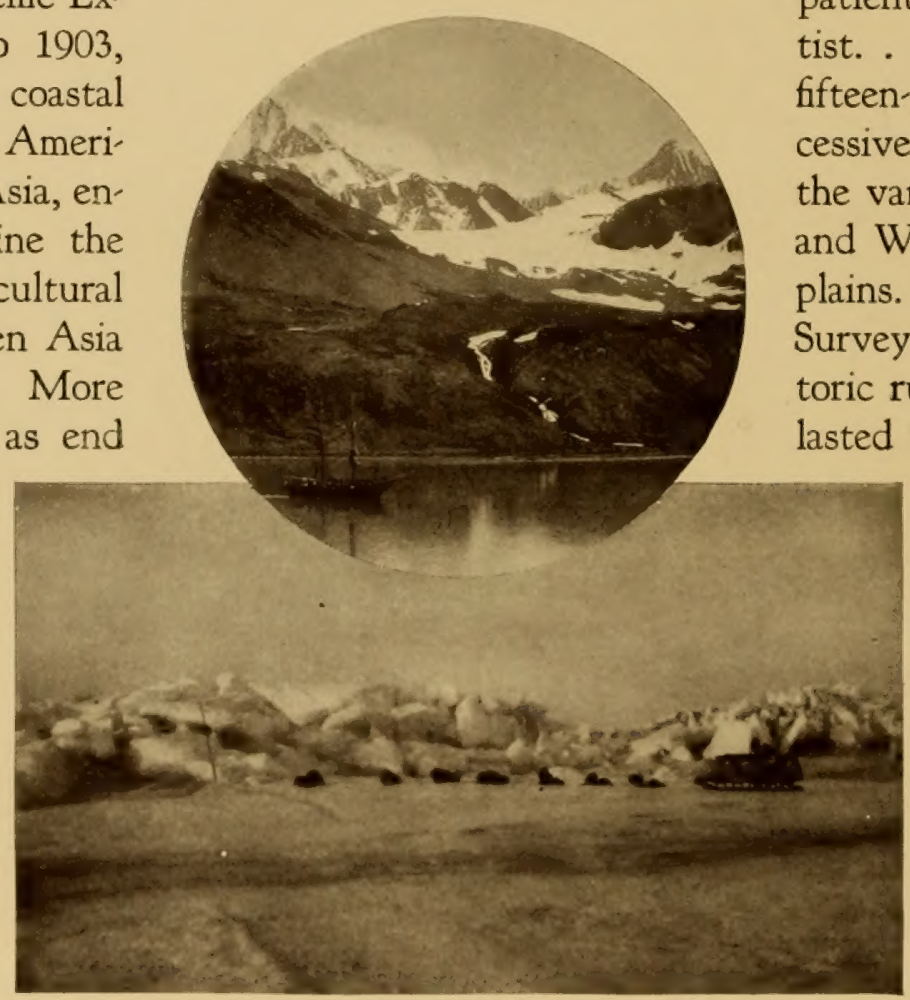

(Bottom) Dog Team of StefánssonAnderson Arctic Expedition. (Circle) Collecting Antarctic Specimens in South Georgia for the Museum
Thus, at the very roots of civilization upon this continent, was commenced the patient probing of the scientist. . . There followed a fifteen-year program of successive expeditions to study the vanishing tribes of East nd West in woodlands and lains. . . . The Huntington urvey of the tribes and prehis. toric ruins of the Southwest thirteen years and included a study of five living peoples and fifteen hundred and thirty sites and ruins in four states, covering an area of more than fifty thousand square miles. In the course of these excavations the Museum, through $\mathrm{Mr}$. 


\section{EXPLORATION}

Huntington's generosity, presented to the United States a now famous ruin near Aztec, New Mexico, which was accepted by our Government and made a national monument.

The recognition of its work, however, which the Museum most values came from an old Indian, who said to the curator-inchief of anthropology: "Now I pass in peace. You have written down our history. You have put away in a safe place the things of the old people. Our grandchildren can read and see what their ancestors did. Otherwise all

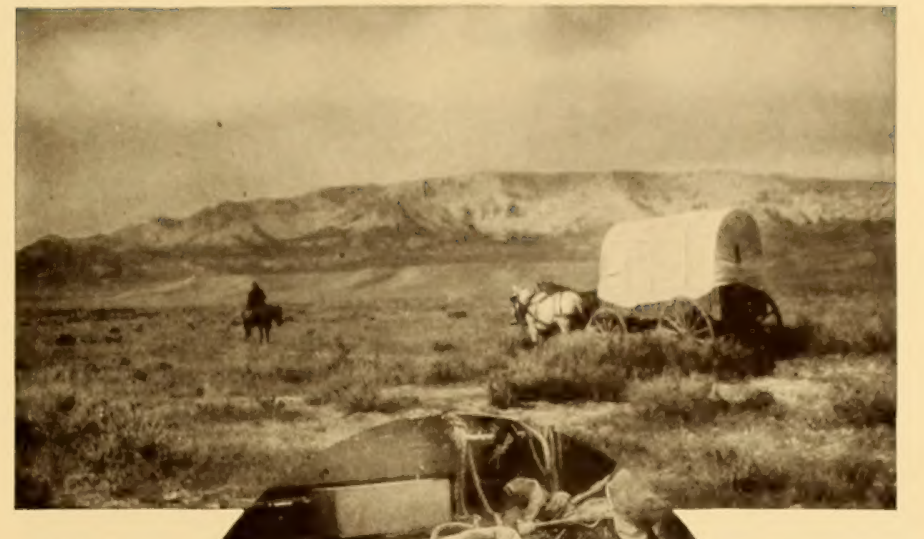

would be lost. It is good that you came before it was too late."

Few realize what a tremendous job American ethnol. ogy and archaeology have done in the classic field of our own Southwest, the

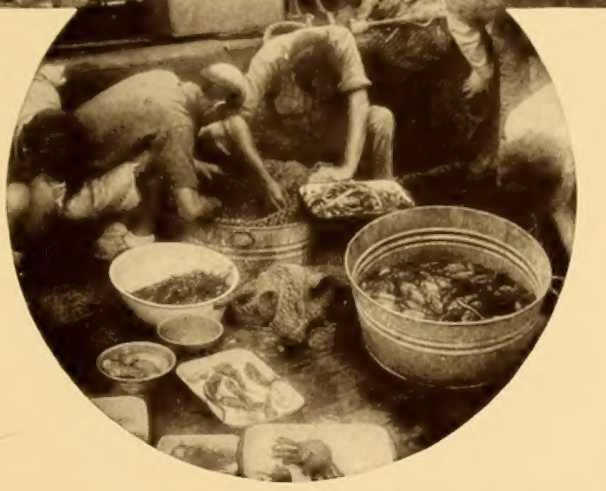

Headed for the Foothills of the Rockies - an Ornithological Expedi. tion. In Circle: On the Deck of the Arcturus, Sorting a Deep Sea Haul center of a superior Pueblo people, preceded by others traced back to two or three thousand years before Christ. From successively buried layers of broken pottery in rubbish heaps and from a com. parative study of the growth rings in old trees now living and of the corresponding rings in the dead timbers of ancient dwellings, American

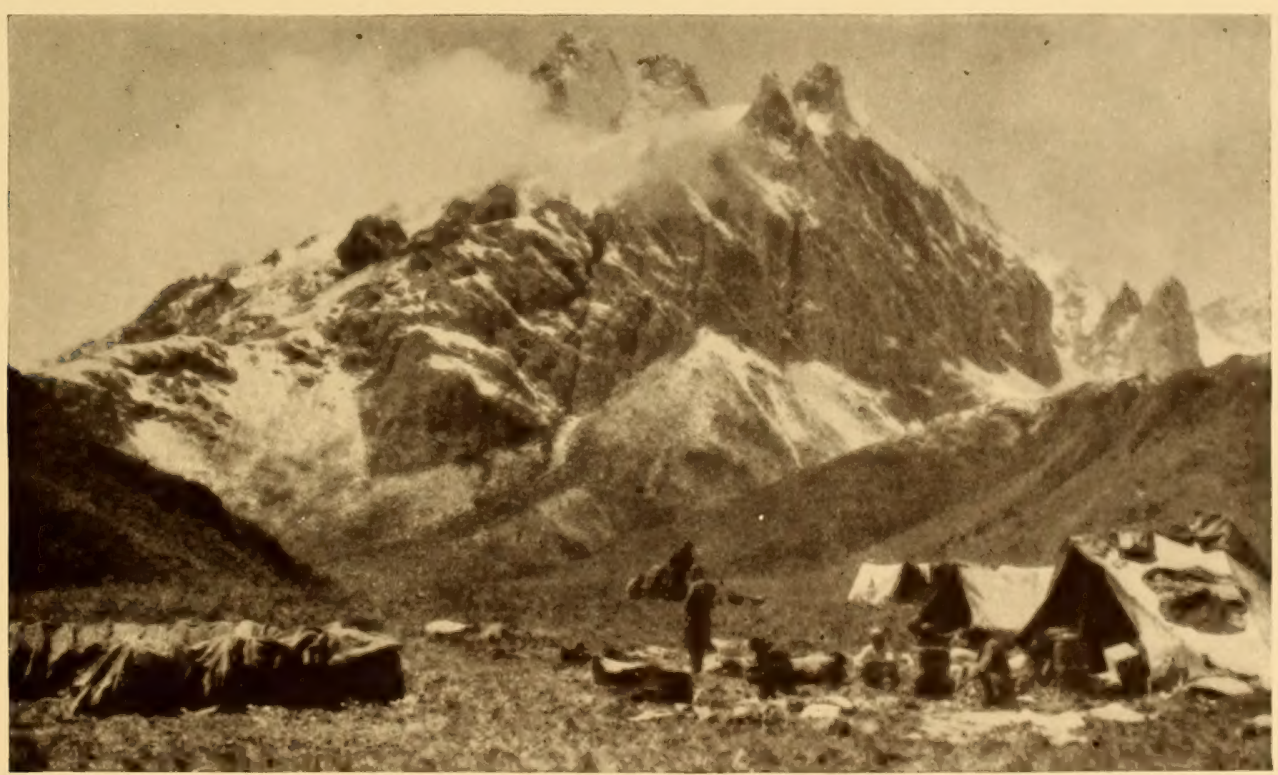

Eleven Thousand Feet Up in the Mountains of Chinese Turkestan-Object, Ibex 


\section{EXPLORATION}

Museum men have devised, or caused the devising of sys tems for the relative dating of ruins and sequences of cultures the age of which was previously a matter of conjecture. So accurate have these "time

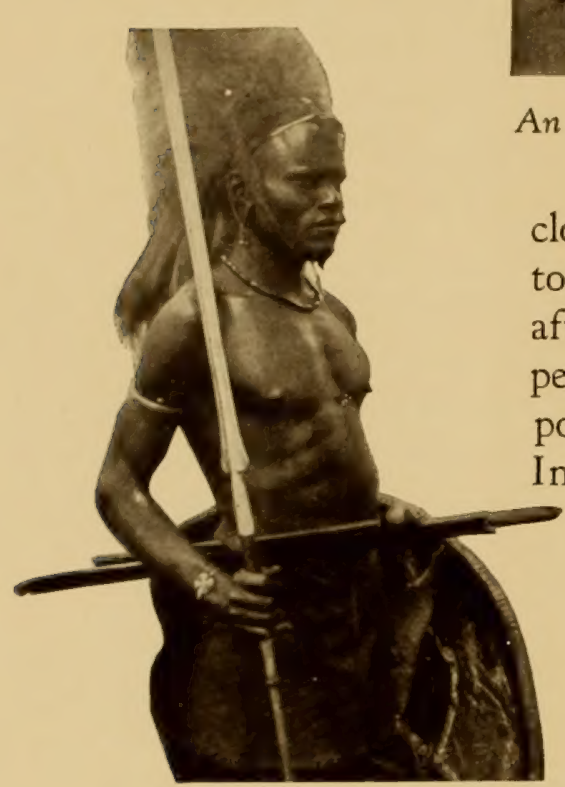

Right and Left: Nandi Spearmen of

of the ruined cliff houses of Colorado with an authentic realization that he is "upon hallowed ground, where the first wild hunters from Asiatic shores took up their residence, to be succeeded in turn by weavers of baskets, then by raisers of corn and cotton, by skillful potters, domesticators of the turkey, builders of temples and finally the architects"... of

clocks" proved, that today, three decades after the Jesup Expeditions, the anthropologist whom the old Indian commended

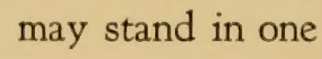

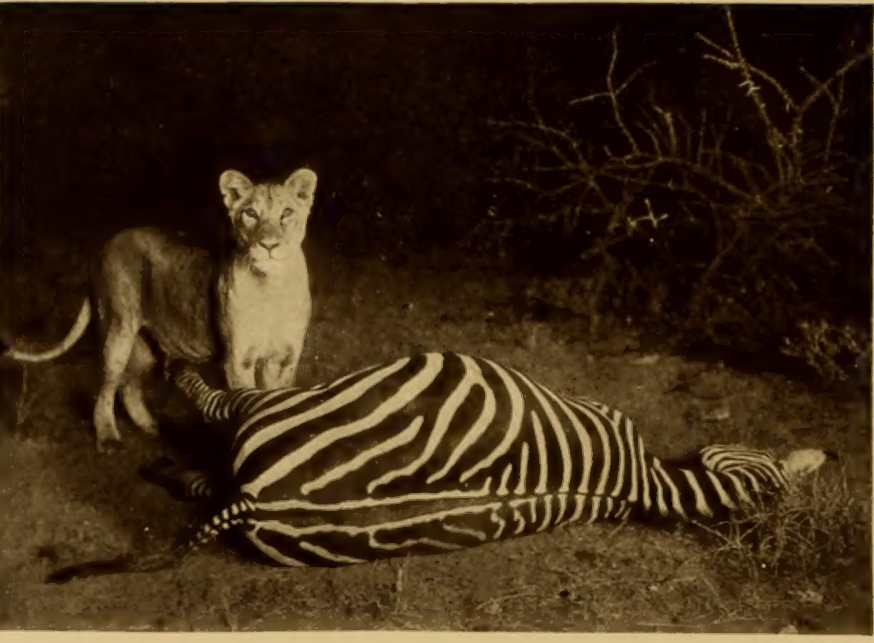

the cliff palaces themselves.

Thus is the prehistory of our own country being laid bare, while staff archaeologists stand ready to try out in Central America and Peru the newer dating methods

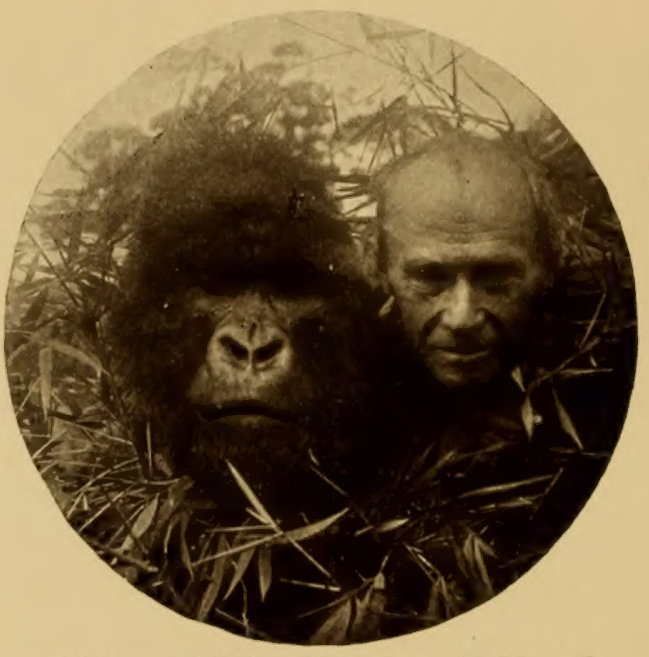

Akeley and "The Old Man of Mikeno" found successful in the United States. This may seem a strange statement to one who believes we already know all that is needful about $A z$, of America, is now thought to be but a blossom on a far older stem; that the oldest of the preceding "archaic" cultures is not tecs, Mayas and Incas from the researches of
such scholars as those who from the researches of
such scholars as those who have built up the $\mathrm{Mu}$ seum's notable collections from these fields. The
truth is stranger stillfrom these fields. The
truth is stranger still-
that the civilization of the truth is stranger still-
that the civilization of the ancient Mayas, the Greeks the Type Sculptured by Carl Akeley

tecs, Mayas and (n) 


\section{EXPLORATION}

"archaic," but relatively sophisticated in its art techniques.

If the 1930's yield as many far-seeing Jesups and Huntingtons as the 1900 's, there is no computing the results of an exten. sion of the Museum's present anthropological program into Central and South America.

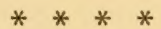

Across the world, in the depths of the Gobi desert of Mongolia, a train of automobiles, supported by a supply caravan of camels, conveys that mod. ern exploration unit, the Central Asiatic Expedition, into the heart of a former continental plain, now a great elevated basin rimmed by mountains. That it is one of the world's oldest land masses was the discovery of the Expedition

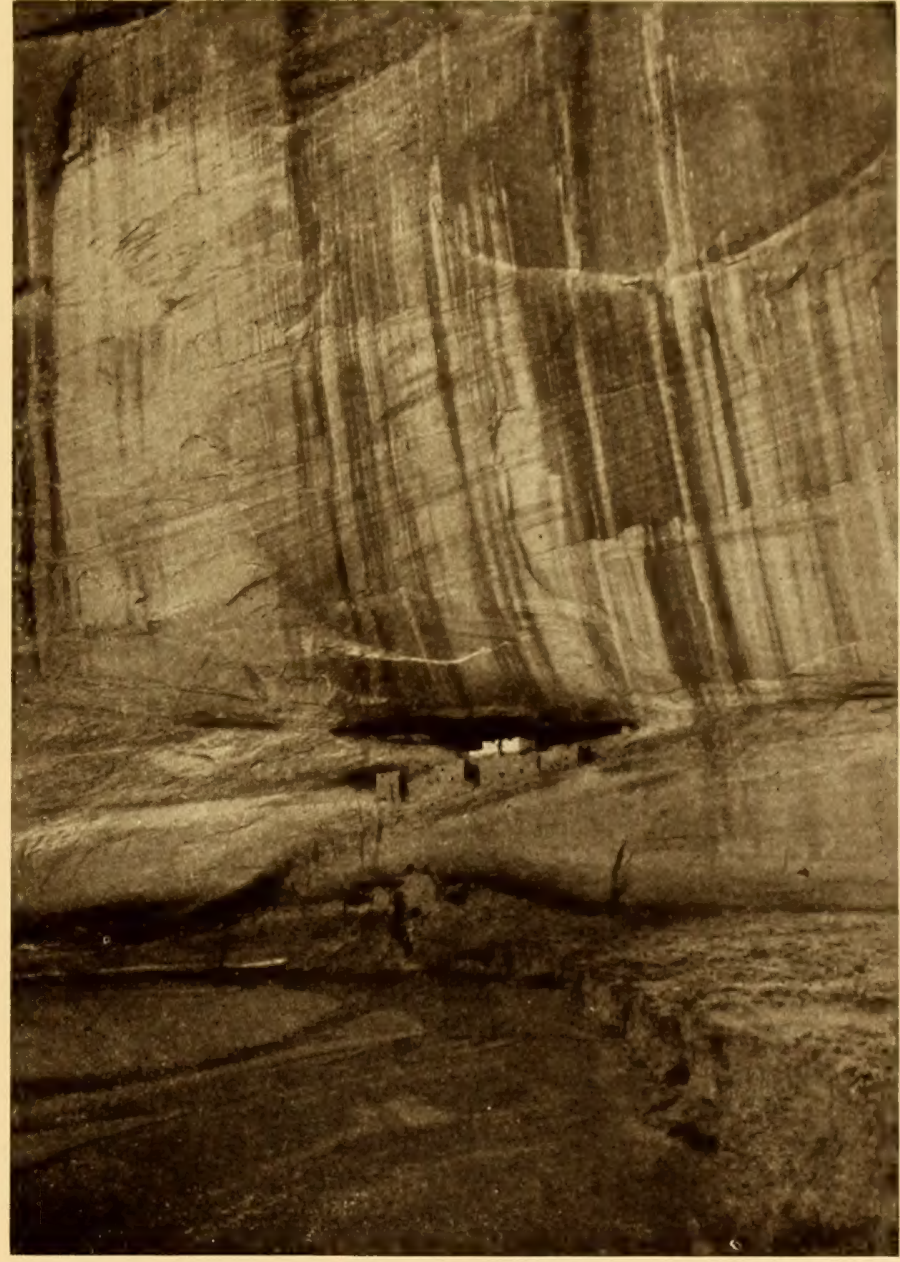

An Older American "White House"-a Cliff Palace of the Ancient Pueblos almost military in its organization, which is attacking a seeming waste of sand with all the resources which a full complement of specialists can bring to bear. Here geology, palaeobotany, palae. ontology, archaeol ogy and zoology combine to reconstruct the living past of this dead region. Now in its ninth season, the Expedition is still upturning the fossil evidences of that past as its contribution to the history of life on the earth, and expecting, if it can be maintained in the field, to find in the womb of Mother Asia the early embryonic traces of her lastborn, Man. . . .

Important collec tions have been made on every con tinent, but the primary aim of the Museum's depart ment of vertebrate palaeontology has while testing out the theory of the President of the American Museum that this ancient terrain was the homeland and dispersal center of most of the mammalian life of the globe, including man. All readers of newspapers are familiar with the successive and spectacular fossil finds of this scientific scouting party, been to gather representative fossil series which should present the historical develop ment of the evolution of land vertebrates in North America, a program so vast that after thirty-nine years of continuous labor it is not yet fully completed. Fossil-bearing strata from Alaska to Mexico have been made 


\section{EXPLORATION}

to yield up the bones of great dinosaurs and extinct mammals - mastodons and titanotheres, little four-and three-toed "horses" and small camels, sabre-toothed tigers and giant ground sloths - all the incredible beasts that roamed our countryside from a million to a hundred and fifty million years ago.

The huge king of the Hall of Dinosaurs, Tyrannosaurus rex, first of his name and species, was found entombed in a sandstone hill in the Badlands near Hell Creek, Montana, a hundred and twenty-five miles from a railroad. Sixteen miles of road had to be built, and plows, scrapers and dynamite used to remove him from his bed. Pelvic bones, encased in solid sandstone, weighed

four thousand, two hundred and fifty pounds after all surplus rock had been removed down to the bone, and it required a six-horse team to haul this block to the railroad. . . . Seven carloads of bones of great antiquity were shipped into the Museum from the Freezeout Hills of Wyoming - four carloads floated down the canyon of the Red Deer River of Alberta, Canada, on barges. Fossils have been found in Alaskan gold mines and North Carolina coal beds, in California tar pools, Arkansas caves, and in the crater of an extinct volcano in New Mexico. The jaws of a mastodon were excavated at Dyckman Street and Sherman Avenue in New York City. Thanks to the present use of the airplane for reconnaissance many new fossil areas may be located. . .

What is the purpose behind this steady, systematic piling up of specimens to replace or supplement old ones now overflowing five ex. hibition halls and numbers of cavernous study rooms? Is it that the Museum shall be able to say, with Professor Alfred S. Romer, that its vertebrate palae. ontology department, having the largest, fin, est and most varied collections in the world, has, in less than four decades, "risen to an unchallenged position of leadership in the field?" That it serves as a world center for palaeontological research which can scarcely be under taken anywhere without reference to this department's collections and research publications? The purpose goes even deeper. It is the true determination of the origin, evolution and dispersal of the great animal groups of the earth. . . .

From a study of these fossil finds it has been possible to work out, here in North America, the development of the horse from a small, fourtoed denizen of subtropical areas, which was, in fact, not yet a horse, to the present large, onetoed plain-dweller. More, it has been possible to name North America as the theatre of evolution and worldwide dispersal center for the horse and camel families - the chief transport agents of man from primitive time. Confront- 


\section{EXPLORATION}

ing the evidence afforded by the Museum's specimens, particularly its remarkable synoptic series of fossil horse skeletons ranging from an early period in the age of mammals to modern times, Museum research is able to picture the evolution not only of the horse and to a large extent of the camel, but of our own West from a warm, marshy land bordering the great inland sea which is now the Gulf of Mexico, to the elevated dry plains and mountain ridges of the present.

Through palaeontology evolution has received its most impressive proof. Through the study of fossil material it has been pos. sible for the President of this Museum, as founder, curator and builder of this department, to conduct his fundamental researches in former land connections throughout the world. From such studies as these emerge the facts that North and South America were first joined, then separated, then rejoined; that Asia and North America were once joined. These connections have been geologically dated from chart ing the periods of animal migrations as attested by the fossil sequences found. . . .

For a "dead" science palaeontology contributes to human knowledge exceedingly live data - yet so far has but scratched the earth's concealing surface. ...
Exploration programs undertaken by or for this Museum are, of course, of many kinds. There is the thorough, systematic work of the department of mammals in South America, in the field with one or more expeditions each year since 1910, whether alone or in association with the Museum's ornithologists - a persistence that has rewarded the Museum with the most varied collection of South American animals to be found anywhere. . . . There is that stirring venture of two British sportsmen, Arthur S. Vernay and Colonel J. C. Faunthorpe, who set out to make for an American museum the finest selective collection of game animals ever brought together to represent the fauna of India. . . . A fauna fast disappearing, be it noted, because of the spread of cultivated areas, because of disease and the depredations of greedy commercial and amateur hunters. The provin cial potentates who assisted the two Eng. lishmen in their scour ing of the plains and jungles of India and Burma were invited to come to America to witness the dedication of the result - South Asiatic Hall, surely the most beautiful museum hall in the world. It is the consummation of the dreams of an architect, a staff of animal sculptors, landscape painters and preparators, Museum officials - and the donors. To the 


\section{EXPLORATION}

visitor it seems that the silent but expressive inhabitants of the Hall are proud of serving in perpetuity as perfect representatives of their dwindling species.

From India to the High Andes is no great step for American Museum exploration. There, on slopes reaching an altitude as high as 23,000 feet, with banded life zones rising from the Tropical to the Arctic, it has been possible for the bird department to study birds as in a laboratory, since a mountain, with its climate belts, is the world in cross-section. What are the natural laws controlling the distribution of these birds, differing in form according to climatic zones? Whence came their ancestors to populate such "new" mountains as the Andes? ... What have been the evolutionary changes in species? . . It seems immensely obliging of Nature thus to permit human science to serve as laboratory assistant while she conducts an intensive biologic experiment on a continental scale.

Simultaneously, in the South Seas, the Whit- ney Expedition, launched in 1920, is still sailing from island to coral island - many unexplored by science-lying in the scattered groups that make up Polynesia. There is being amassed the largest systematic study collection of South Sea fauna, chiefly birds, ever assembled. The representatives of many a new species and genus have already been described. Usually the size of such prospective new collections is a matter for as much concern to the Museum as rejoicing. Indeed, in this case, even though the collection is to be generously housed in the model Whitney Wing, topped by a skylight aviary for live study specimens, it will still require classification, preparation and years of specialized study - all of which will cost more than the expedition itself. . . .

Cost what these collections and expeditions may, continuing them is an obligation of civilized man, who has set himself the task of finding out what is, what has been, and what will bethe evolutionary history of life and its environ. ment, the earth.

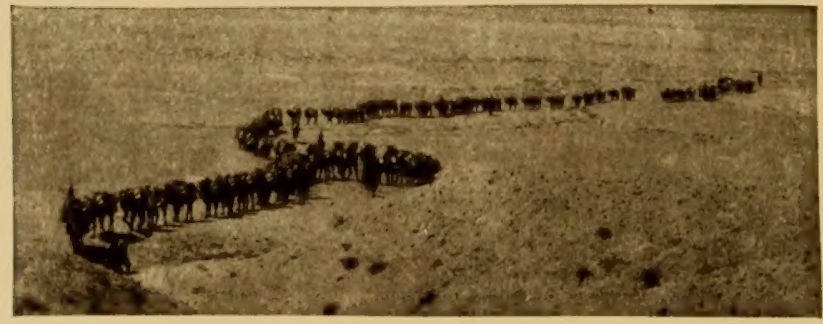




\section{RESEARCH}

$\mathrm{L}^{\mathrm{ET}}$

IT BE understood at the outset that, merely for convenience, the subjects of American $\mathrm{Mu}$ seum exploration and research are treated separately here. The notations set down under these two head. ings could quite as well be transposed.

For example, when the curator of marine life devotes years to a study of coral reefs in different parts of the world-is that not both ex ploration and research? What is the proper classification for scientific work done in comparative anatomy to determine the exact sequence of body structures from fish to manwhen it involves the sending of an investigator to Australia, Greenland and Africa for observations and material? Or, for that matter, merely across the Hud. son, where the Museum's chief geologist goes to dig for cross sections of the clays once deposited every year by melting glaciers in the last ice age. From a count of these annual lay, ers of summer and winter sediments it becomes on

Studying the Habits of Salamanders in the Laboratory

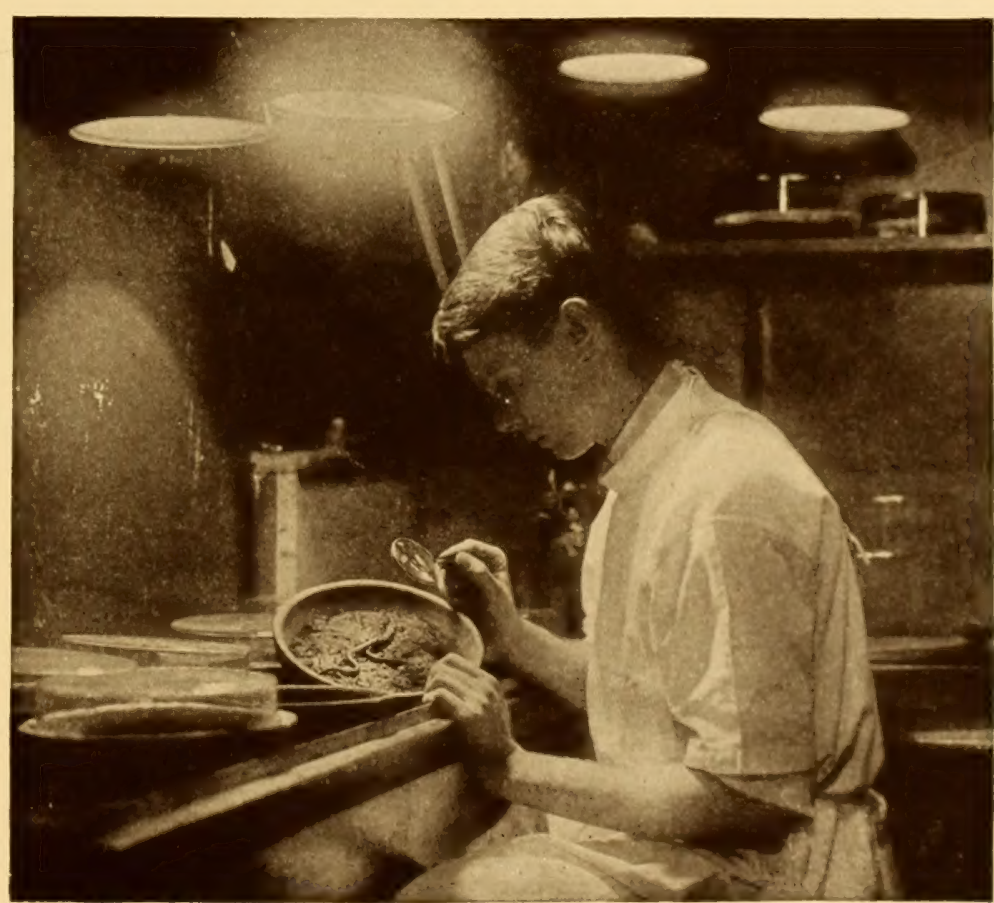

possible for him to say: The glaciers over the Hackensack valley took twenty-five hundred years to retreat; those over a portion of the Hudson valley, seven hundred. . . .

Still other pieces of straight $\mathrm{Mu}$ seum research are done in the field, even though it be a near-by field. As before noted, an ichthyologist need go only fifty to sixty miles from his office to bring up deep sea forms for study, and not as far to secure even more interesting fifty fathom specimens from a narrow, mysterious belt near the outer edge of the Continental Shelf, inhabited neither by deep sea nor shore fishes but by peculiar exotics whose nearest relatives are to be found in the Mediterranean and Pacific. ... .

A backyard serves both as exploration field and as research laboratory for a curator who, if he had lived in the Middle Ages, surely would have been revered as a wiz. ard versed in black magic and acquainted with some of the dark secrets of $\mathrm{Na}$ ture. Within his microcosm, the world of insects 


\section{RESEARCH}

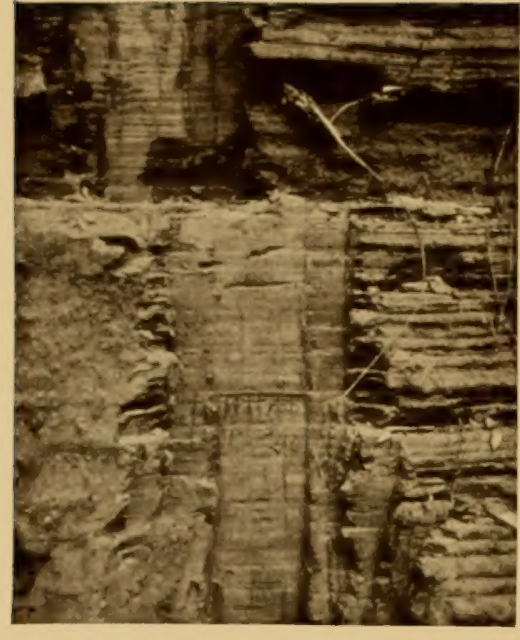

(a world of half a million species, or three-fourths of all the species in the animal kingdom), he conducts experiments uncanny in their encroachments upon the borders of the unknown. Insect sounds inaudible to the human ear are recorded with the aid of a movietone amplifier. Ultraviolet rays invisible to man are demonstrated, by a series of subtle studies, to attract insects when reflected from the flowers they frequent. Imagine a detailed scientific monograph analyzing the cricket's chirp, with its range impossible for a ny human prima donna

All this Apparatus Concerns a Cricket and His Chirp, Re. corded by Movietone Amplifier

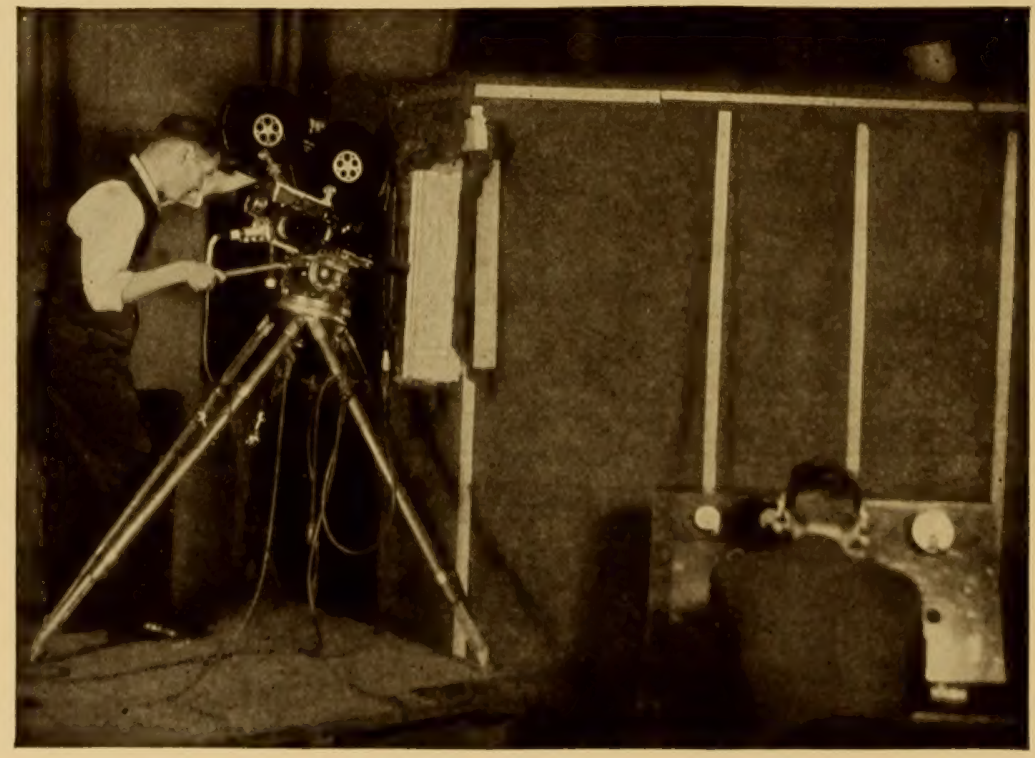

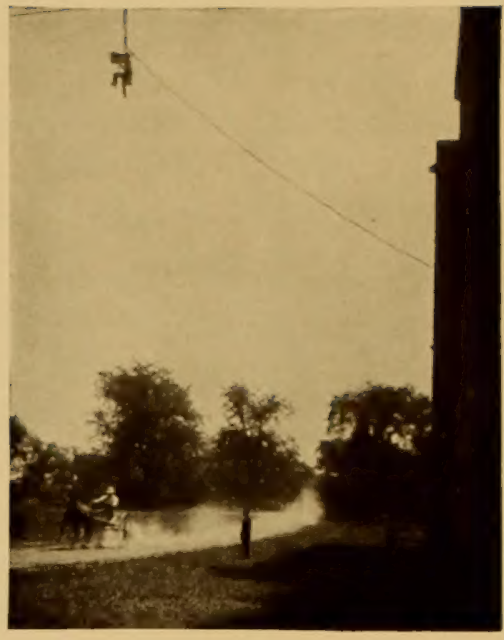

fully to hear, much less rival!

The race track is at times the incongruous setting for the research of one $\mathrm{Mu}$ seum authority of scholarly dig. nity. His old-world politeness must impress even the dazed hostlers who lead horses up and down, or run them, for the "professor" to observe as he lies in the dust or on the roof of a stable - even suspended on a seat fifty feet in the air-study, ing and photographing their motions for reproduction in marvellous skeletal mount ings. Nowhere else in the world are there motion studies in bone like these, which should be labelled, like sculpture: Man 


\section{RESEARCH}

Reining in a Rearing Horse-Racing Wolfhound-Sysonby, Champion Race Horse, in Action, et cetera. . . .

A dark, slippery cave in the Missouri Ozarks, inhabited by a species of blind salamander, is the strange scene for one of the labors of a herpe. tologist bent on discovering whether the young of the species retain the potentiality for sight despite the generations of blind ancestors behind them - a question answered affirmatively by rearing them in the sunlight of the laboratory. ... Shift the scene for another act to the little island of Komodo in the East Indies and we find a young Trustee of the Museum playing the rôle of St. George for the herpetology department and slaying the largest dragon lizards in the world for a habitat group. ... Shift again to Haiti and Santo Domingo for still more research. . . .

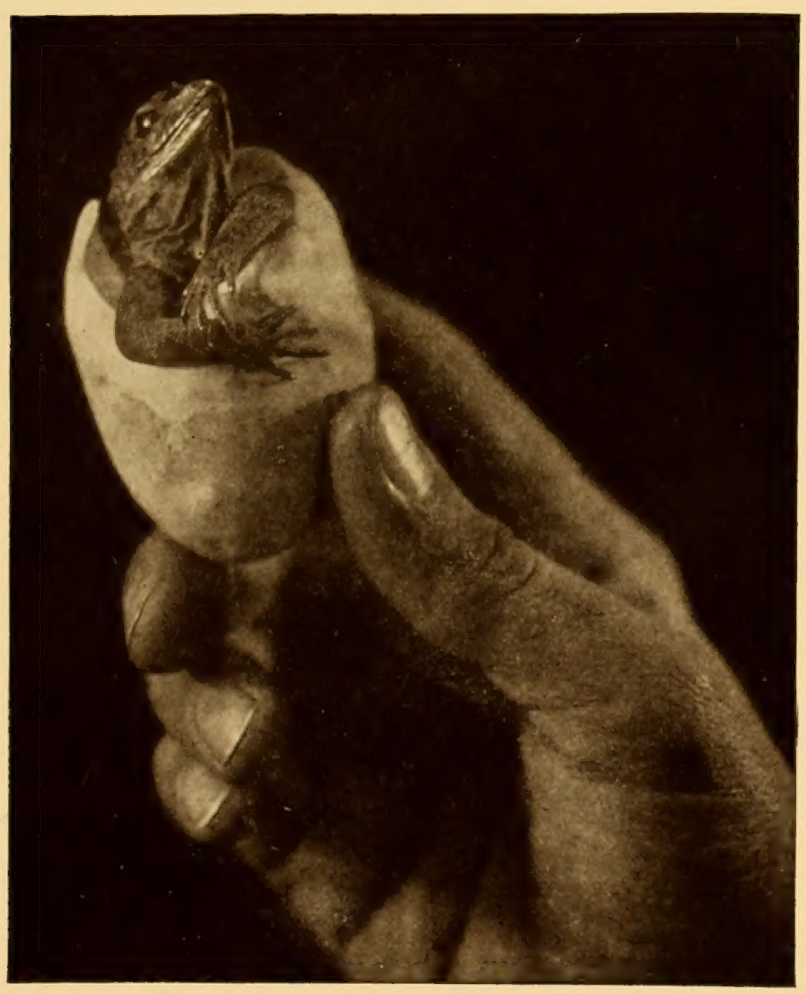

An Iguana Makes His Debut in the Museum

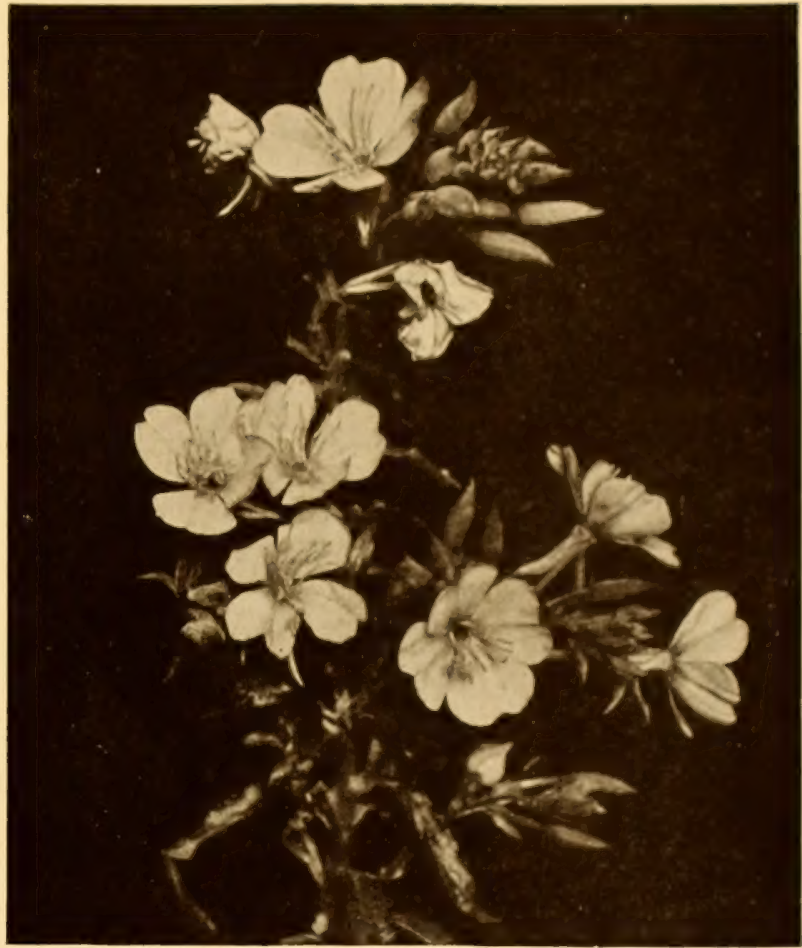

". . . a Yellow Primrose Was to Him," But to Insects it is Ultra-Violet in Reflections, as Proved by a Series of Subtle Museum Experiments

There is a kind of Museum research, how. ever, that has come indoors, though it still depends upon expeditions or field work for its live material -indeed, receives its chief impetus from the availability of fresh field specimens assured to it by the work of the great natural history museum of which it is a part. This research has grown out of the American Museum's increasing realization that to prove any. thing fundamental the newer discoveries in biology - especially in genetics and animal psychology - must be applied to life as it occurs in Nature. It is not enough, any more, for naturalists to discover, describe and classify new forms - even to study their life histories and relations to their environments. Outside of museums, experimental biology has forged ahead and by actual laboratory experiment with the factors of growth and evolution has shown 


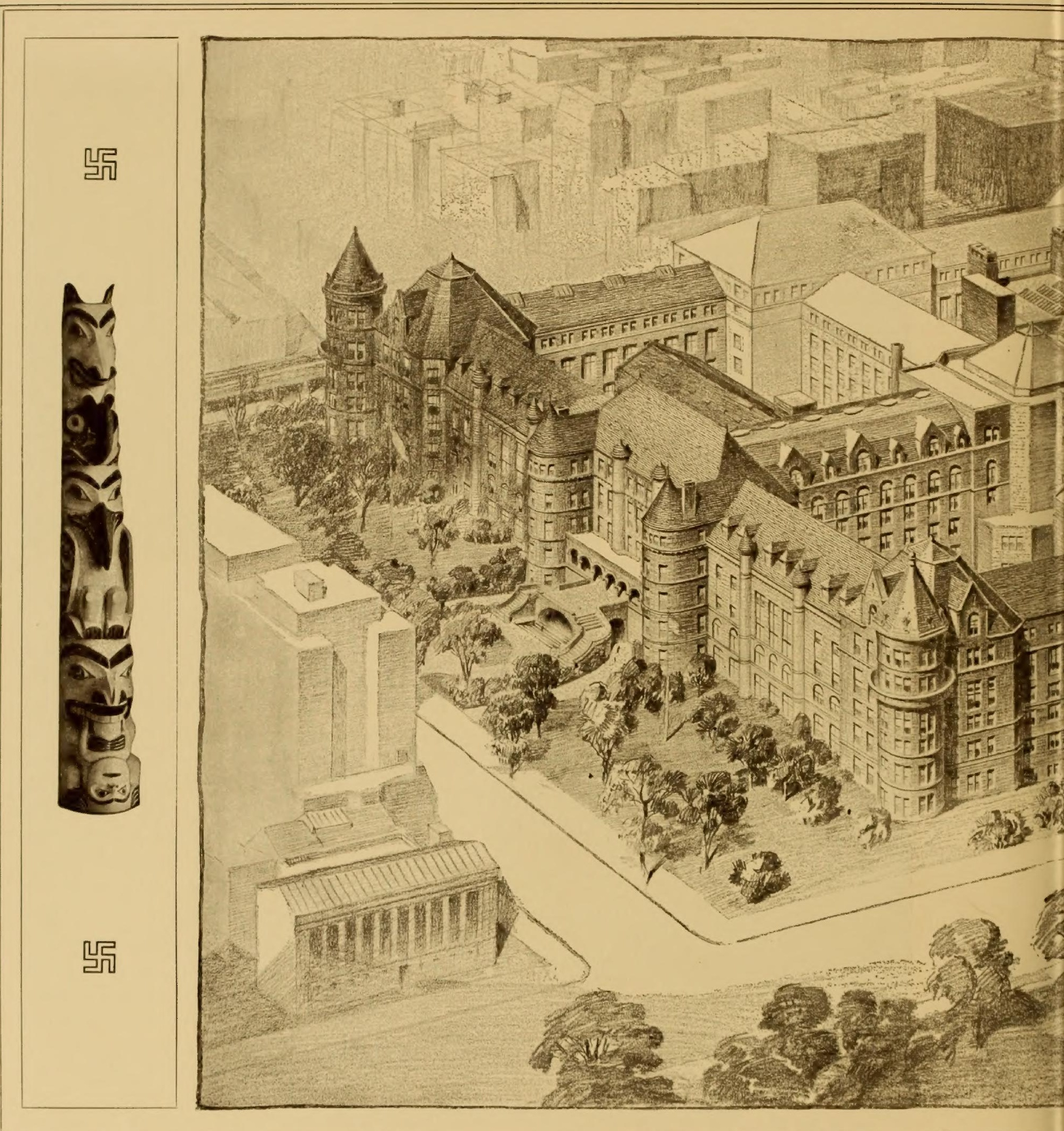




\section{RESEARCH}

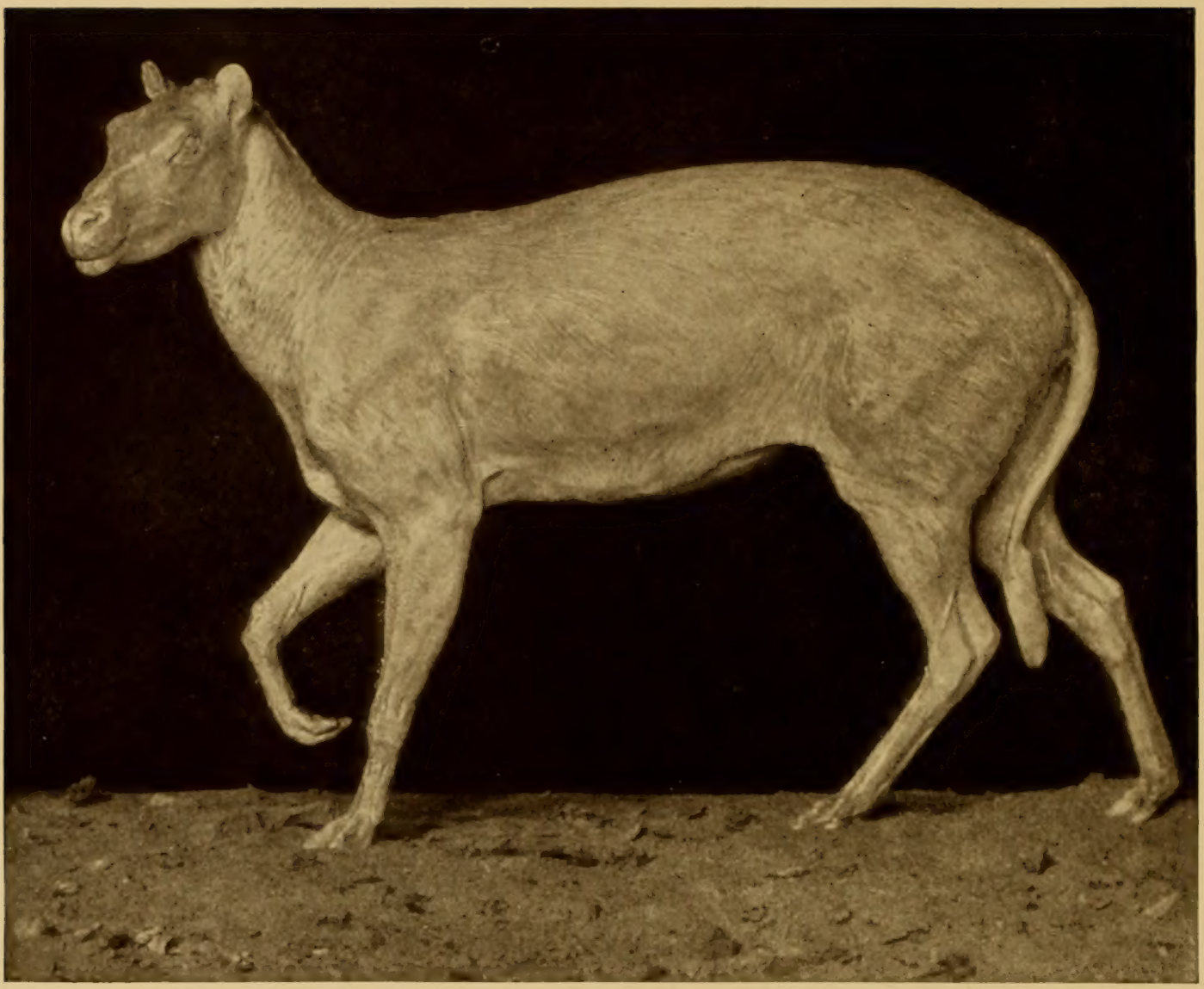

Eohippus, the Four.Toed Horse of America's Eocene Period, Thirty-five to Forty Million Years Ago

the naturalist the real hereditary units of his species. It has shown that chemical body messengers, such as the internal secretions of endocrine glands, control growth of the body and in large measure reproduction and animal migration. It has demonstrated the origin of instincts - has bred at will new characters, new forms - has reduced phylogeny to an experimental science, controllable by man.

The natural history museum should, of course, be the final authority on questions concerning the kinds of animals in the world, their structure and functions, their past migrations, their origins and their interrelationships with the environment; just as the museum should be equally well informed on the changes which have occurred in the inorganic materials of the earth and universe. Unfortunately, however, due to lack of funds for adequate department personnel, most museum curators find themselves, in their efforts to pursue lines of research, swamped by field and executive duties, with little time to do more with their material than make it convenient for others to study. This state of affairs could easily result in museums taking a position secondary to universities, colleges, and research foundations in all fundamental biological questions concerning species, origins, or vital processes which they, as natural history authorities, are obligated to know. 


\section{RESEARCH}

Foreseeing this, the Trustees of the American Museum have taken a great forward step in Museum development by creating a sub-department of experimental biology which lacks only adequate financing, by means of endow. ment, to extend its work beyond the one department with which it is now, for convenience, associated and become the servant of all departments. The next step will be the securing of additional biological investigators disciplined by years of university study in experimental evolution, cell structure and general physiology, who shall be peculiarly fitted to assist and collaborate in problems confronting depart. ment research workers.

Already, in a scant three years of work, the new department of experimental biology has published results of general biological significance - has made important contributions to the knowledge of the hormones which control the breeding cycles of animals, also the effect of the thyroid secretions upon growth. Some of the factors controlling the form of teeth and the color pattern of animals have been discovered. Though these problems so far have been worked out only with reptiles and amphibians, the conclusions are of value to a general understanding of the $\infty$

Pedal Extremities, Ancient and Modern -Without Research No Giant Saurian of the Past Could be Restored processes producing the infinite variety of form and color found in Nature.

Nature is a strange and subtle Sphinx, but man is making so bold as to question her - not generally, but specifically, under a third degree. ... Under what stimuli do birds migrate? Exactly what makes newly hatched turtles without ancestral memory crawl to the sea, or fish and lizards change color like kaleidoscopes? What is the sensory apparatus of the robin that it can hear an earthworm in its burrowof the male moth that flies through a forest at

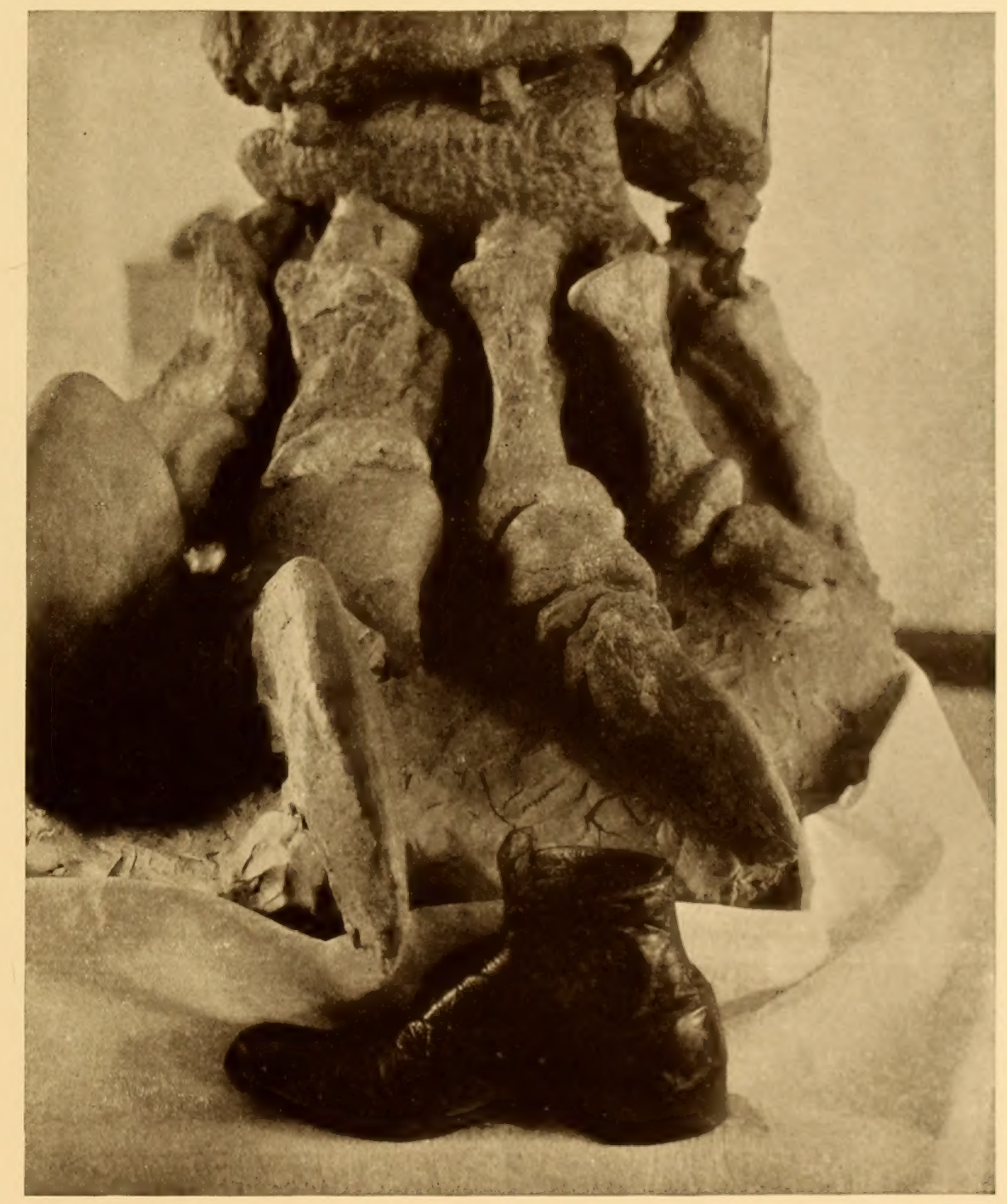

$\rightarrow$ Page Thirty-one If- 


\section{RESEARCH}

night guided only by the odors of the femaleof the bat which avoids obstructing branches by analyzing the echoes of its flight? What are the biological laws behind the organization of animal colonies - of the different types of

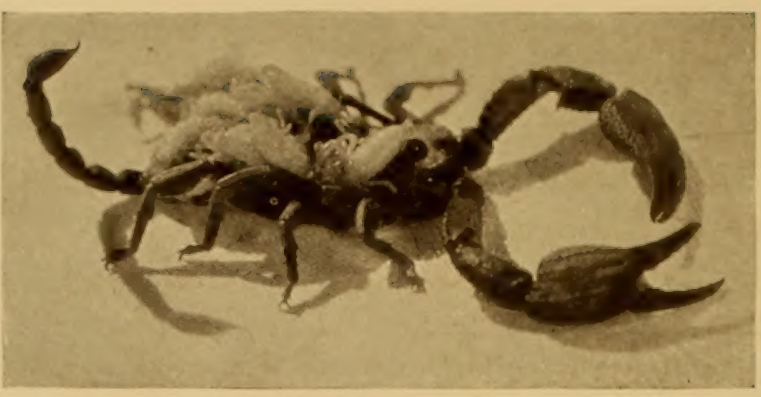

Born in the Museum, Under the Sign of Scorpio

something of gorilla psychology under natural conditions, and an expedition, under the joint auspices of the departments of comparative anatomy of the American Museum and the College of Physicians and animal food chains in which one form is food for the next, in sequence?

For any animal to be thoroughly known, it must be studied from many as pects, anatomical, physiological and psychological. . . . As early as 500 B.C., Hanno, the Carthaginian navigator, brought gorilla skins back from his memorable coasting voyage along Africa, and these skins were displayed in the Temple of Melkarth, the museum of that day. Many ex. plorers have since that time collected trophies of this much misunderstood primate. However, it remained for Yale research to go into the field to learn

Three Diverse Subjects of Museum Research

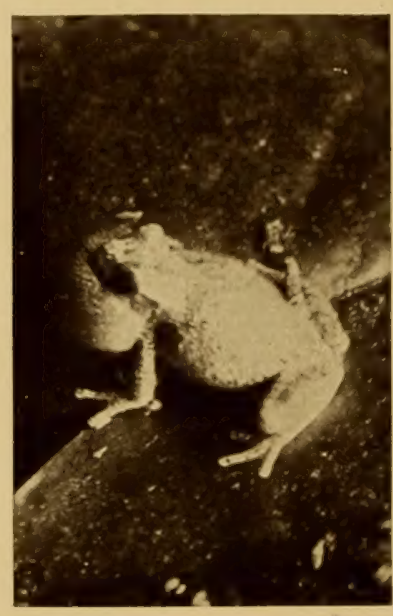

Surgeons of Columbia University, is now in Africa endeavoring to complete the Museum's anatomical data. ... .

A museum, in short, is not a mere natural history exposition for sightseers, in which bits of Nature in great number and variety are beautifully reproduced; it is not only an institution for making man aware of the world in which he lives; it has the higher purpose of discovering the laws which have regulated life from the remotest ages. But this great work depends for its support on the amount of vision and enlightened self-interest active in the Museum's constituency, the American public.

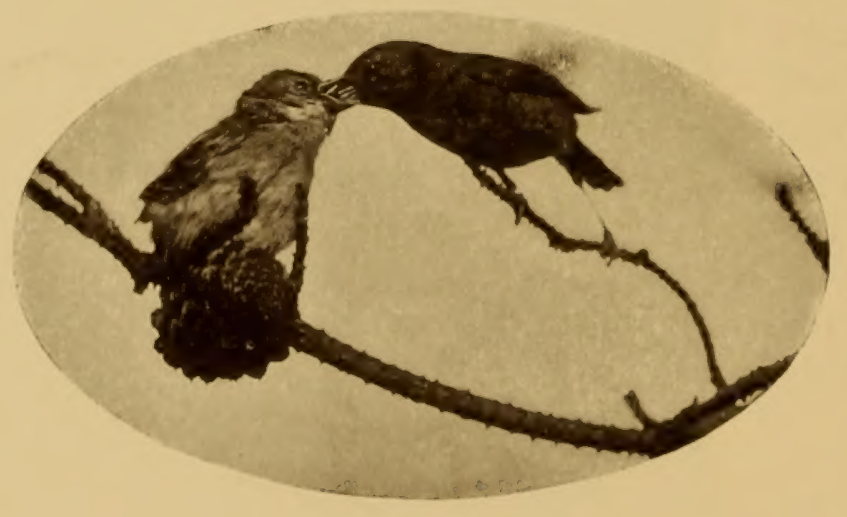




\section{PREPARATION}

$\mathrm{B}$

EHIND screens bearing the pro-

vocative sign, "Not Open to the Public," is the central atelier of the Museum's department of preparation, vested with the Jehovah-like function of breathing life into dead bones and dry skins.

Hanging on a frame in this huge, highceilinged studio, full of artists and craftsmen at work, are the tawny skins of lions and tigers, soft inside as chamois from tanning. Over near a window labors the besmocked chief of preparation, a former pupil of Carl Akeley and sculptor of repute, whose bronze of an African rhino is said never to have left Roosevelt's library table. $\mathrm{He}$ is modelling in clay an African antelope, a delicate, nervous creature with veins standing out in relief along the face and limbs. A tinier clay mod. el, innumerable pencil sketches and measurements made by him while exploring in Afri. ca, field photographs of living antelopes, and

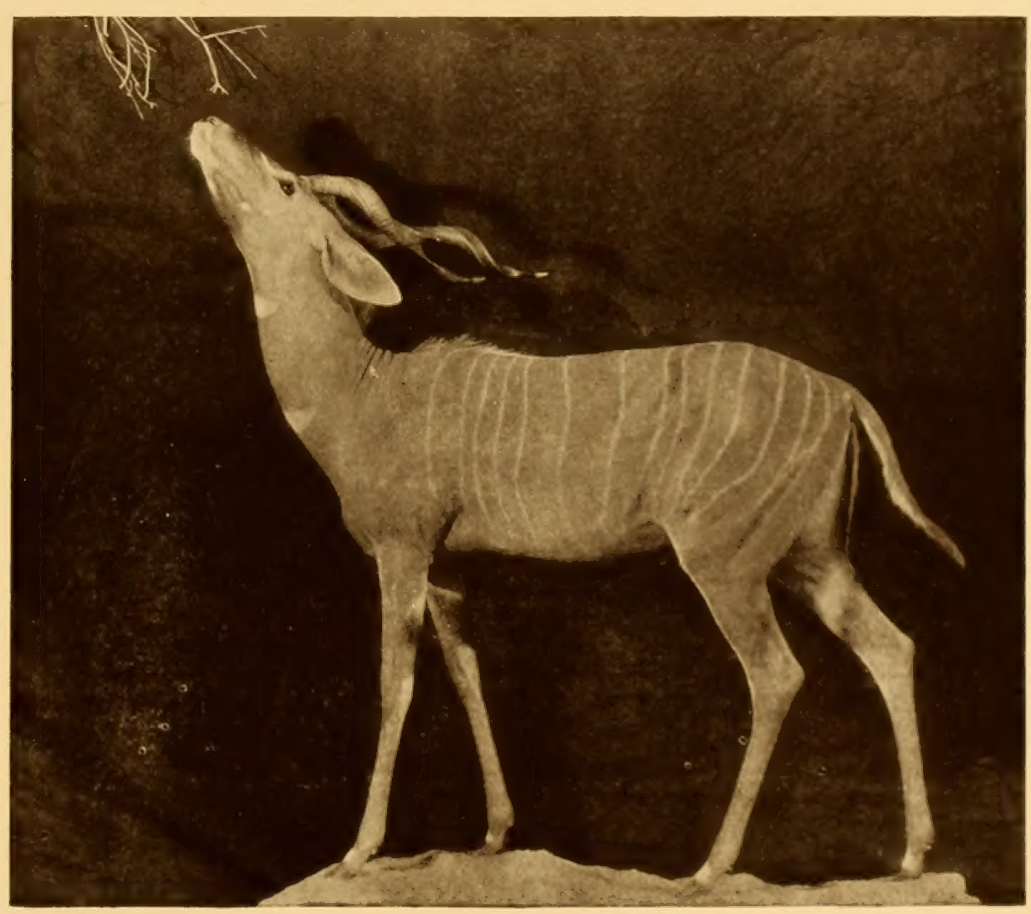

Almost Alive - Thanks to the Department of Preparation the skeleton itself, inside the clay, all serve to guide him. From time to time he tries on the skin as a tailor might, except that he is more interested in knowing whether the body fits the skin than vice versa. Of that body a plaster mold will be made and, inside the halves of the mold, will be built up, in layers of sized fabric, papier maché and wire mesh, a substitute body, hollow, light and thin, to be put together and finally covered with the skin as a finished mount. This, however, is not taxidermy, but sculpture. The manikin and final skin covering will show every muscle contour and ripple sculptured freehand by the artist.

Just off the studio a little lighted room serves as a complete model of the great Akeley African Hall to be - the dream for which he gave years of his life, dying of exhaustion from continued overwork collecting specimens on elephant trails and in the fastnesses of the mountain goril la. Entering -1 Page Thirty-three ]- 


\section{PREPARATION}

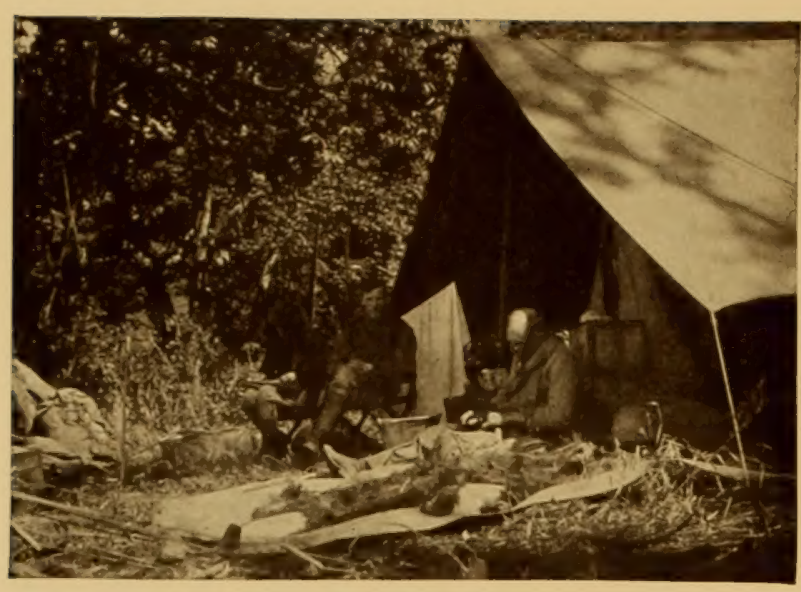

The Man Who Transformed the Profession of Taxidermy into the Fine Art of Animal SculptureAkeley in his Gorilla Camp

this model hall one sees in perfect miniature a sequenced panorama of Africa-animals against landscape backgrounds ranging from the cold, volcanic peaks of the gorilla country to the hot, russet sands and leafage of the plains. Down the center of the room tramples a herd of mounted elephants; in the van, Akeley's big bull and a cow and calf shot by Theodore Roosevelt and Kermit. Between the glowing wall groups stand, as sentinels, the dark, enigmatic sculptured figures of African natives. A whole country here-animals, terrain, people - to be reproduced in the large by the labor of nearly a hundred artists and artisans - sculptors, landscape and animal painters, "accessory men" responsible for realistic foregrounds, carpenters, masons, metal workers. . . .

A word about those artists with the modest

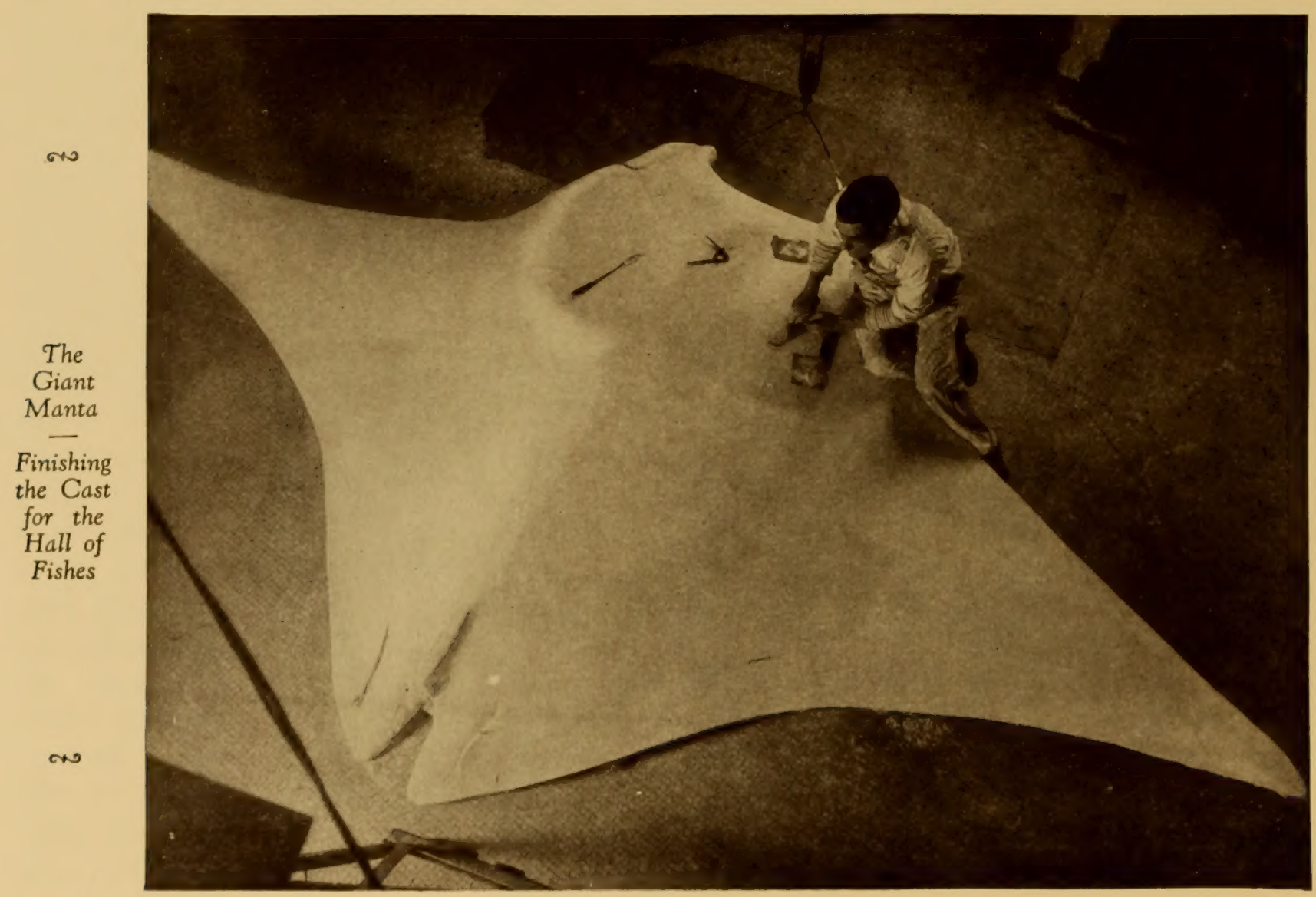




\section{PREPARATION}

title of "accessory men." The leopard group in South Asiatic Hall presents a fairly complete example of their work. . . The scene is a cool, rocky glen in the jungles of Mysore. The very atmosphere seems impregnated with moisture - the moss on the boulders, the darker damp earth edging a trickle of water - a clump of dewy orchids in a tree crotch. Flanged roots of the largest of three trees hung with creepers seem to be exploring for water, as does a broad, umbellated rock plant. There are two leopards, one crouched on a boulder with a dead peacock under his paw. ... Now, aside from the painted background, everything in that group, except the leopards, the peacock, the creepers and a moray tree from India, is the work of the

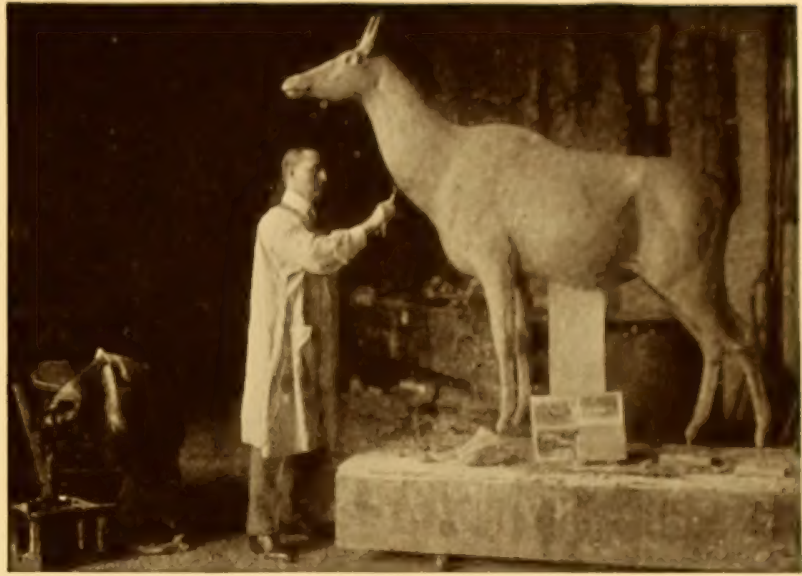

Modelling a Clay Manikin or Perfecting a Huge Mount-All in the Day's Work to the Skilled Preparator-Artist

accessory men. So incredibly real is the setting that one feels like kicking the rocks to see

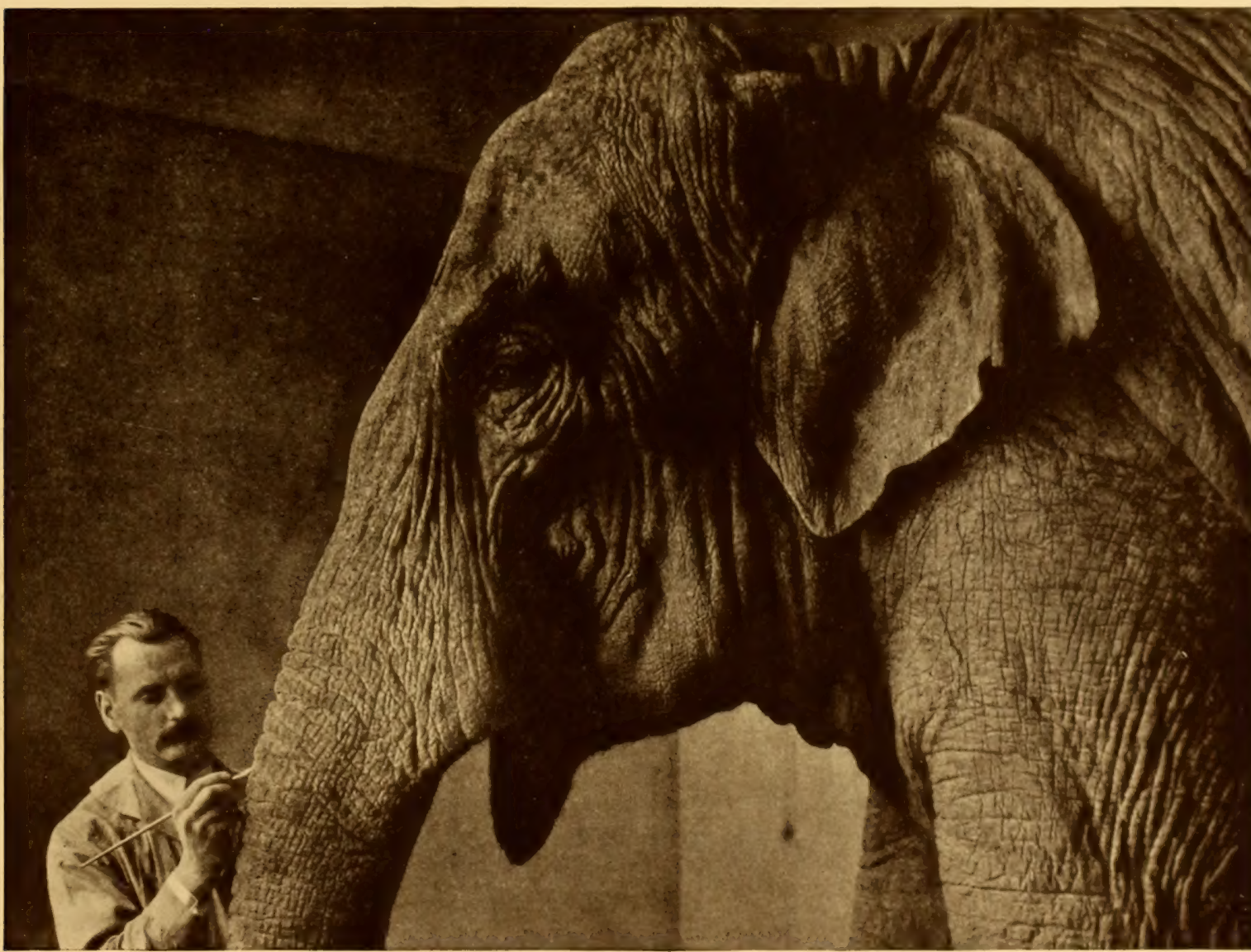

"Vested

with the

Jehovah like

Function. of Breath ing Life" -

Even into an

Elephant 


\section{PREPARATION}

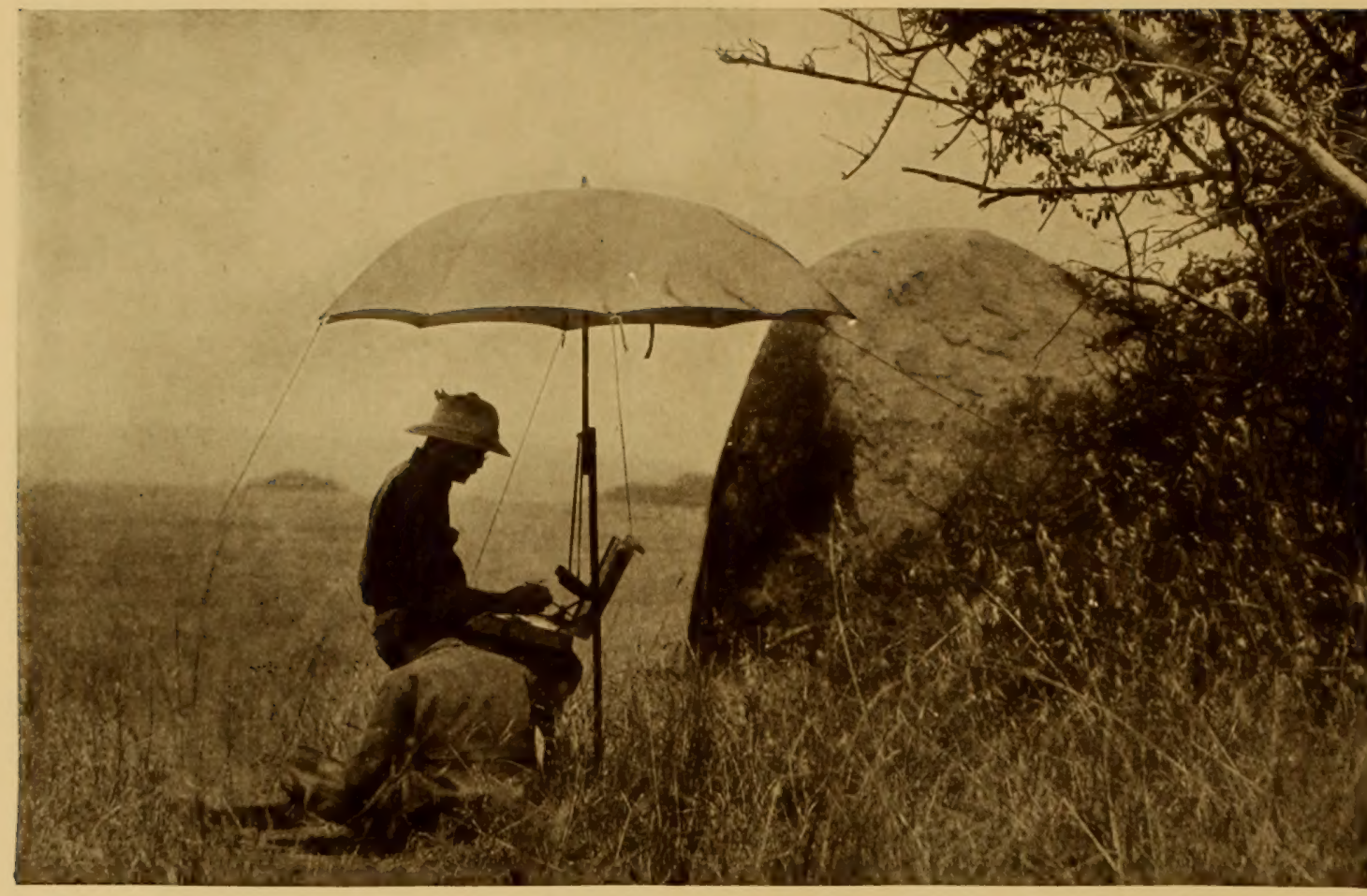

no

Museum

Artist in

Field and Studio

In the Depths of Africa

Recording

Landscapes for

Proposed

Museum

Animal

Groups

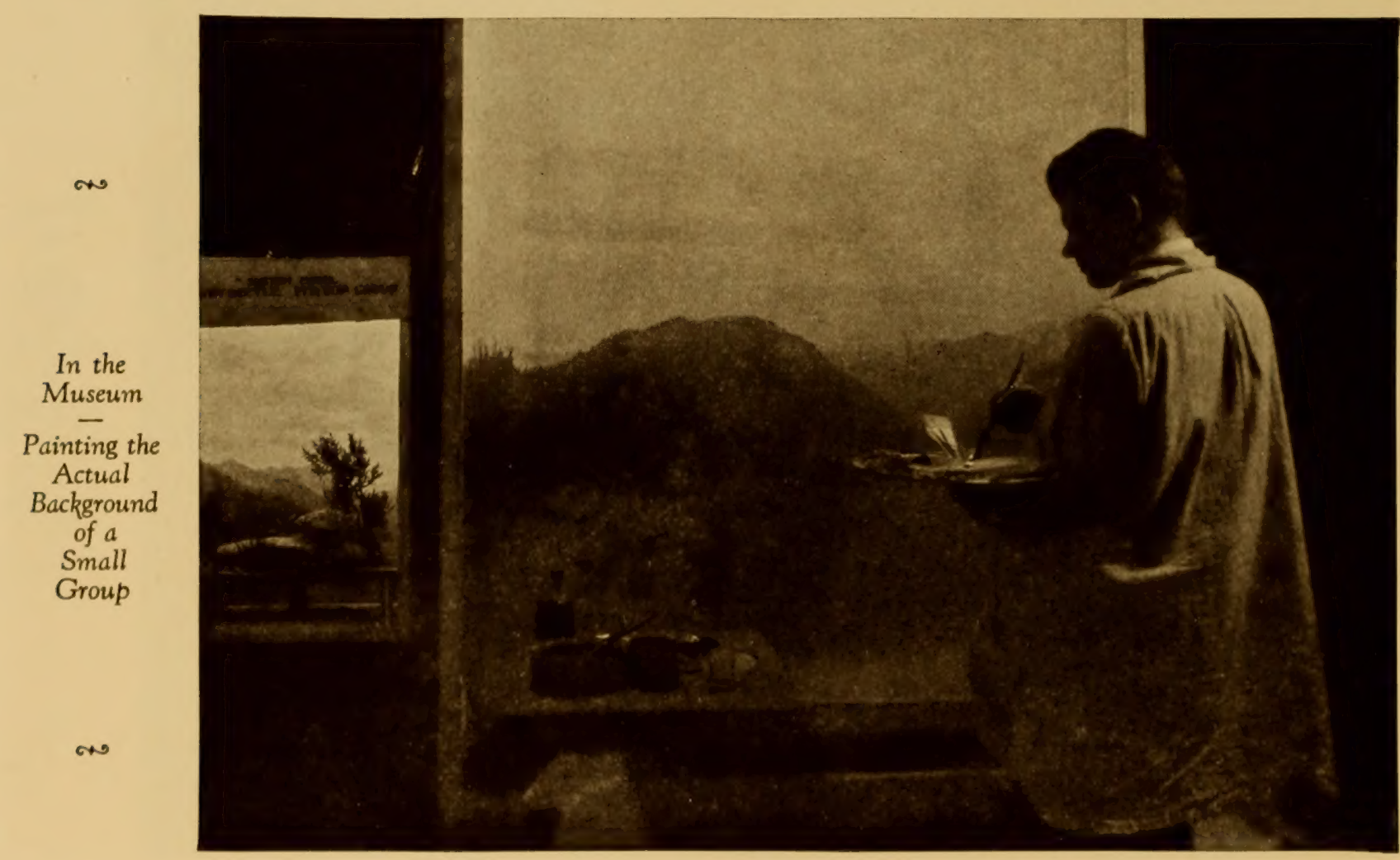




\section{PREPARATION}

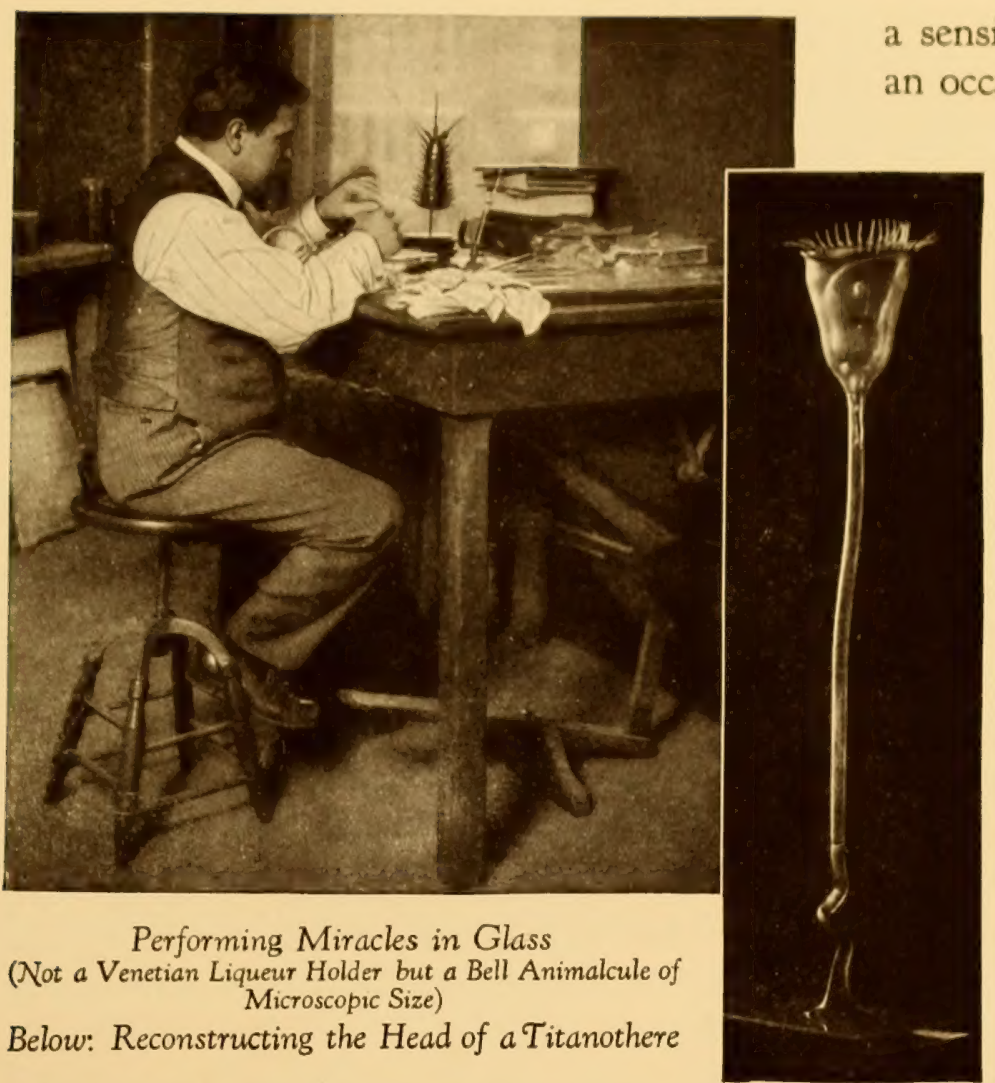

a sensitive-fingered Japanese, is making, with n occasional glance at photographs and color sketches, the hair-like stamens for the frail purple clusters of some small wild legume of Asia. In his glass "hothouse" are cactus and Alpine phlox, dogwood and pitcher plant blooming sociably together in the same indoor climate. Atop a shelf are swathed cotton plants destined for the Hall of Insect Life and showing the life history of the boll weevil.

Across the hall in other preparation quarters a sculptor has just finished for the comparative anatomy and anthropology departments a most public-spirited wax man who is allow. ing his internal machinery to be exposed for the benefit of an interested world! Next door a preparator is mounting a robin for a school loan exhibit. One of his recent jobs was

whether they are not genuine, after all. Only scientific field work on the spot and the most studious skill at home can produce such a composite result.

Glimpses into the accessory laboratories give a hint of methods: From a formaldehyde solution four work. ers extract the actual branch of a West African acacia tree, drawing it, making plaster leaf molds and turning out quantities of wax leaves to be colored, attached to "twigs" and "branches," and fastened to real tree trunks. . . Another artist,

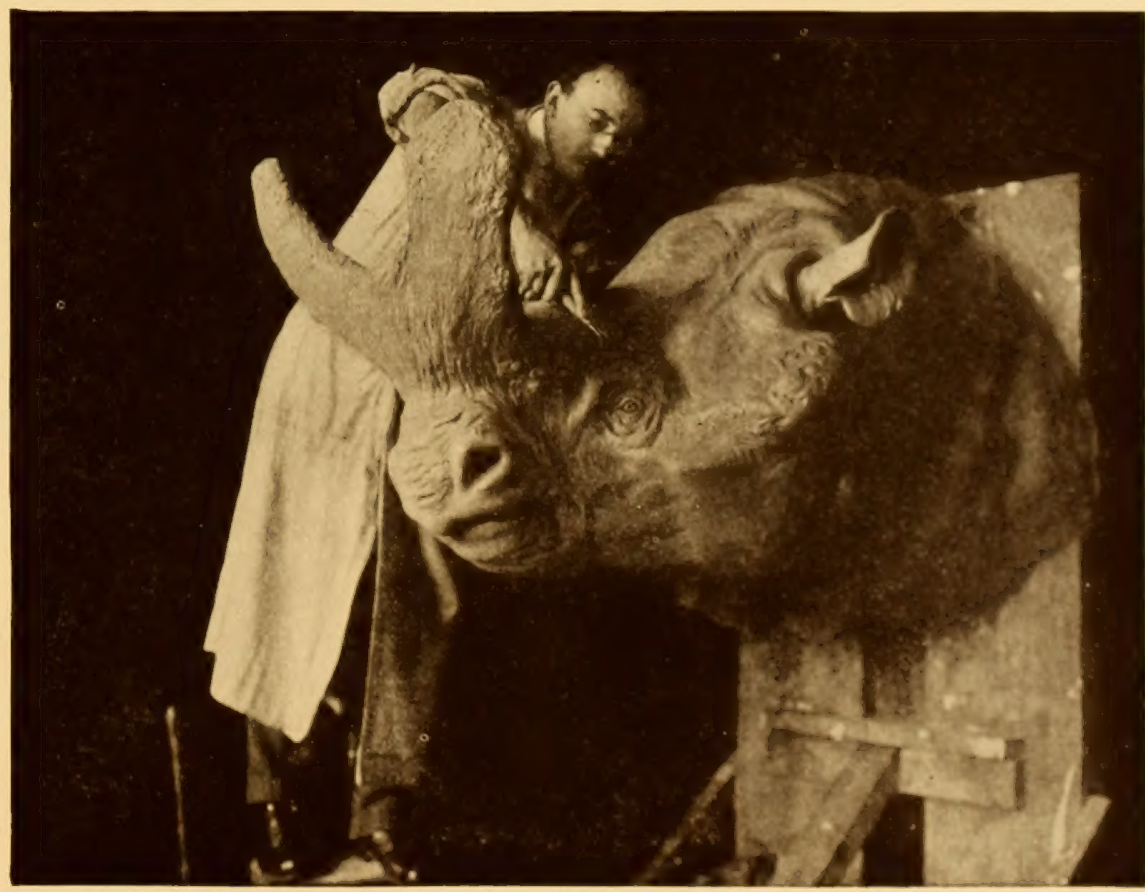




\section{PREPARATION}

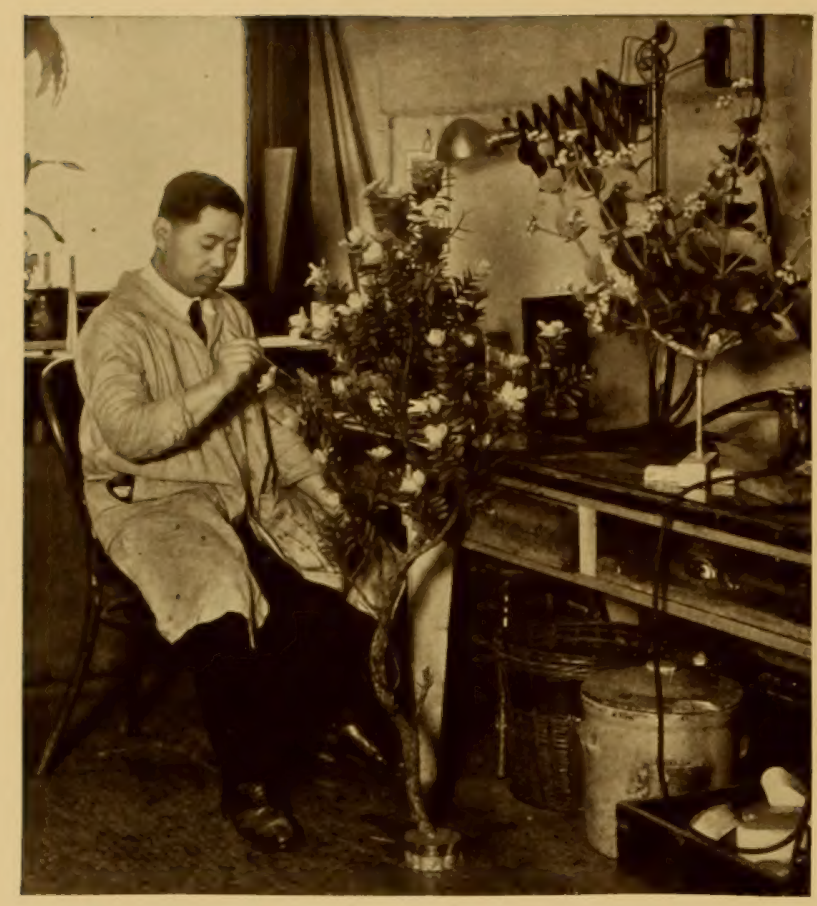

An "Accessory Man" in his Museum "Hothouse" of Waxen Blossoms

to help populate the replica of a whole Panamanian forest with some seventy iridescent feathered residents.

.... No preparator is ever quite certain what he will be called upon to do next. . . . One day, for instance, an obliging young sperm whale blundered into New York Harbor, was killed in a Brooklyn canal, hauled up onto a pier by the citizenry and at once carted to the American no

Not a Scene in Nature, Not Even a Habitat GroubMerely a Two-foot Wax Working Model
Museum to be dumped bodily in the huge, unopened Hall of Ocean Life. It was as if he had swum in to give himself to science. Certainly both scientists and preparators fell upon him in the name of science and rent him from flipper to fluke. Like Shakespeare's ship' wrecked mariner. . of his bones were data made! He suffered a sea change into the lifesized model which now hangs in the Hall.

From whales to pond animalcules invisible to the naked eye is a difference involving infinity - and several Museum floors. In one of the cramped, top-floor workrooms of the department of marine life sits a placid glassblower, born in the Black Forest of Germany, who is serenely indifferent to his fame as the fashioner of unsurpassed marvels in glass sometimes made the objects of pilgrimage by foreign visitors who have heard nothing else about the American Museum of Natural History except that it houses them.

For twenty-five years, under the scientific

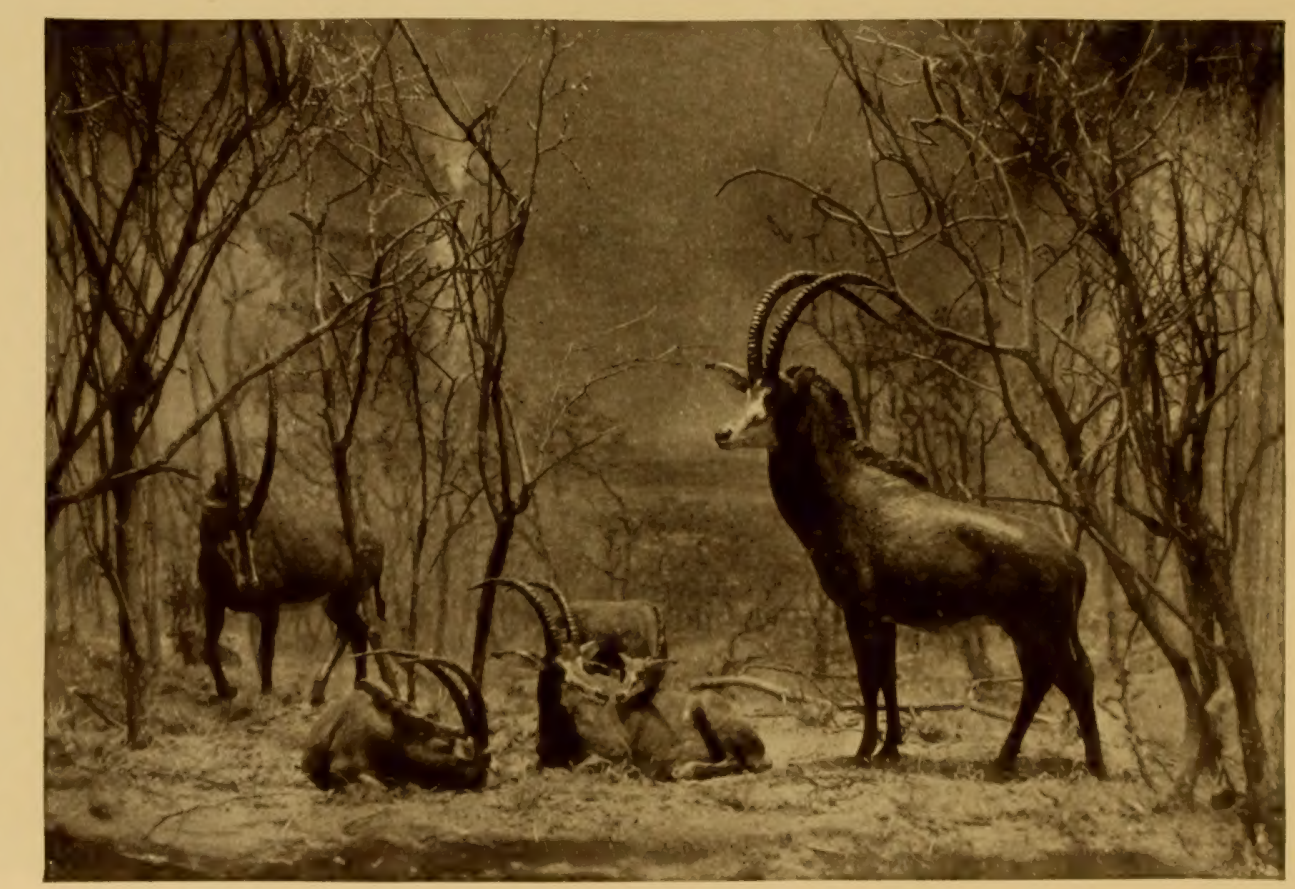

$\rightarrow$ Page Thirty-eight Ip 


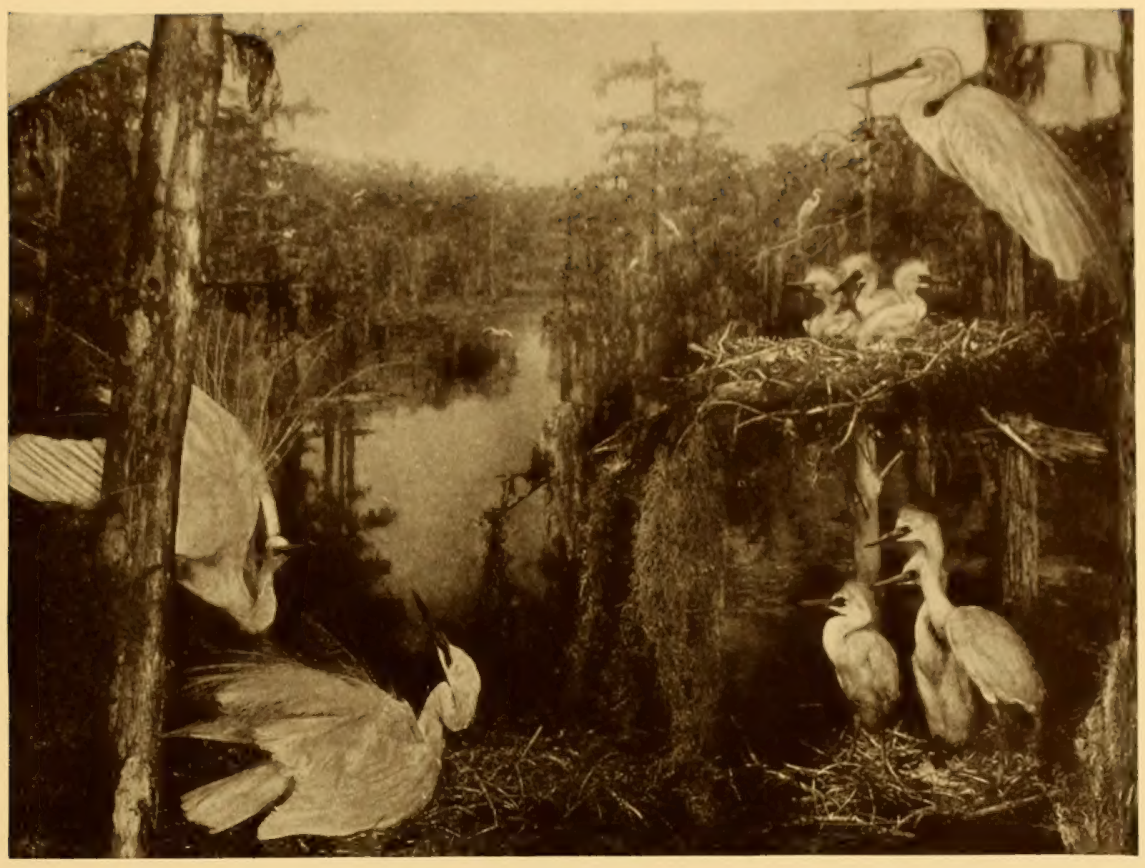

A table ranged with rows of pill boxes full of sand and minute crumbles of bone is the scene of the labors of another preparator-artist, this time in the medium of fossils. On that table were once assembled some of the thousands of fragments now welded into the seemingly perfect skeleton of Hipparion whitneyi, the three-toed desert horse of America's

American Egrets - Not an Inness Painting but a Museum Habitat Group

Below: Deep Sea Pirates in the Dark Room of the Hall of Fishes

tutelage of the curator, he has sat at his workbench before a gas flame capped by nozzles of his own making and, with fewer tools than he has fingers on his skilled hands, has worked miracles. They are to be seen in Darwin Hallfor example, the microscopic inhabitants of a cubic inch of pond water, magnified a million times to show every intricacy of internal structure. Bounded by the rim of a magnify. ing glass, enlarged to scale, is seen a watery world of translucent green, with myriads of strange, exquisite little creatures clinging to silvery reeds and shaken by the same impulses of hunger and fear, belligerence and possessiveness, that compel us.

Like a collection of crown jewels are the near-by cases of fragile, crystalline sea and pond forms, delicately colored or waxed by other department artists. For marine groups one of them paints, from a diving bell, backgrounds depicting undersea coral thickets and sponge groves. ... .

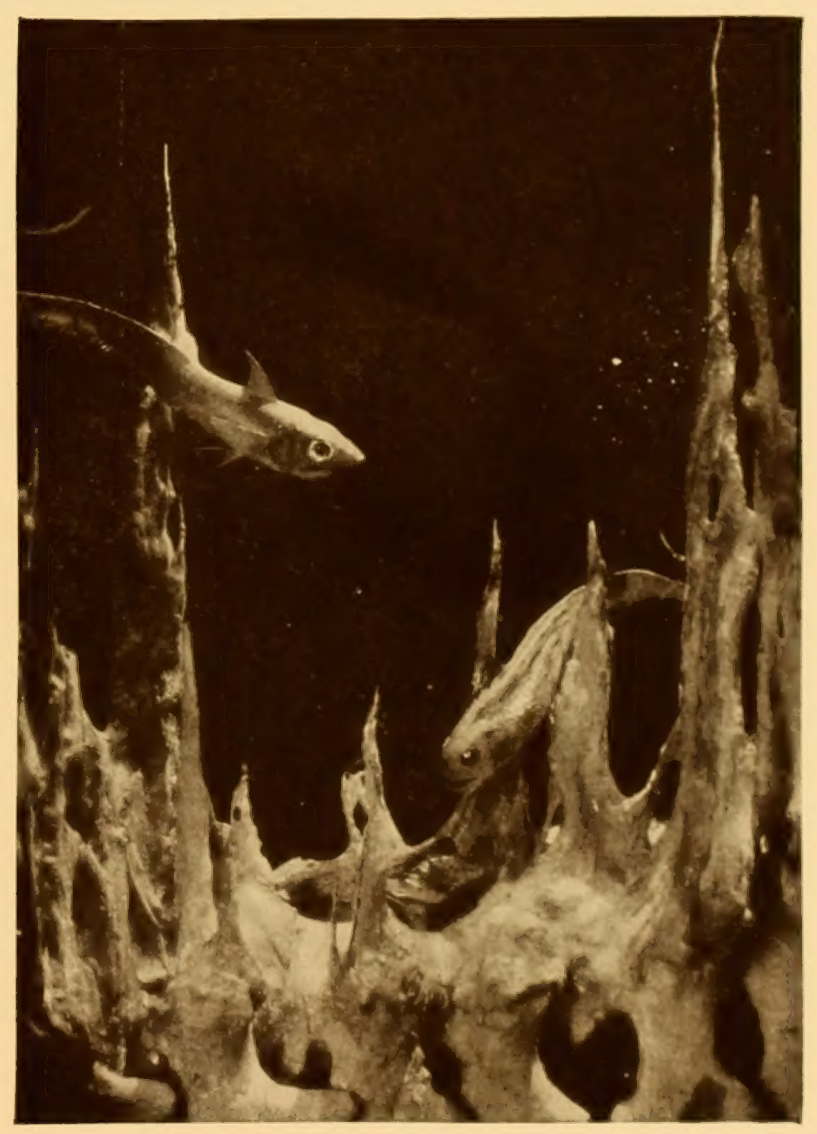

-4 Page Thirtyonine I- 


\section{PREPARATION}

Miocene period. . . . Now, under a strong light, with the aid of a compound microscope, he is restoring the tiny hip bones of a little Triassic relative of both dinosaurs and phytosaurs, about a hundred and twenty million years old and never before discov, ered. So rare was this find that the whole side of a hill was swept down and sifted through a fly screen in an effort to salvage every least fragment. When the parts are pieced together they may afford evidence that a chapter in the science of morphology, or form as we know it, should be re. written. . . .

One classic instance of

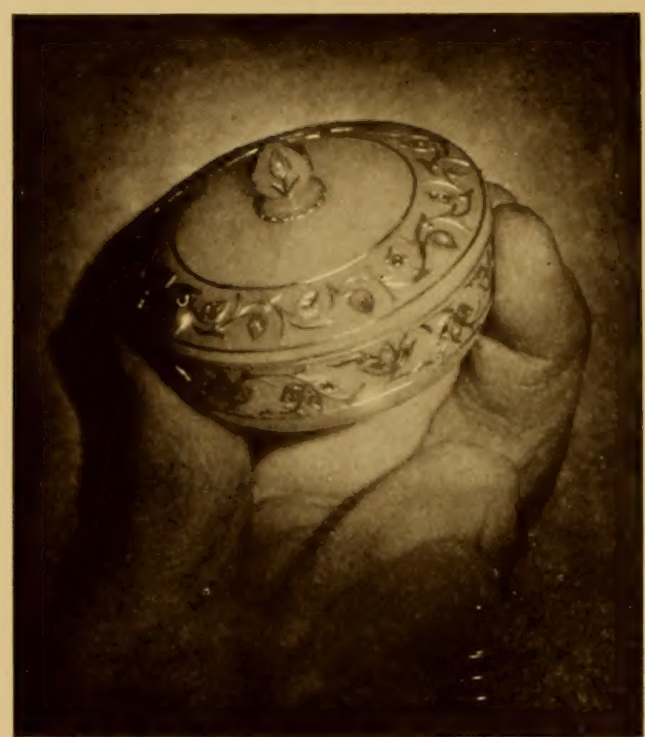

A Cup of Jade Inlaid with Gold, Diamonds and Rubies-From the Morgan Hall of Min. erals and Gems

the value of thorough and accurate preparation of exhibits concerns the famous eighteenfoot model of the Copper Queen Mine of Bisbee, Arizona, in Geology Hall. Examination of this model when completed showed the company engineers that various pockets of ore which had been overlooked in thirty. five years of mining operations could be readily mined. . . .

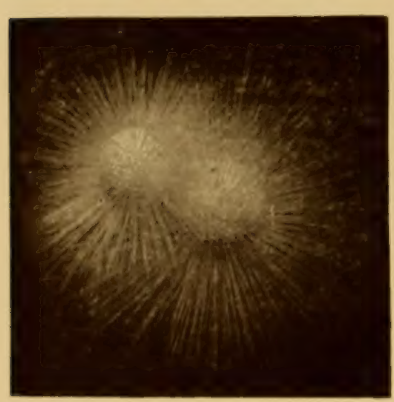

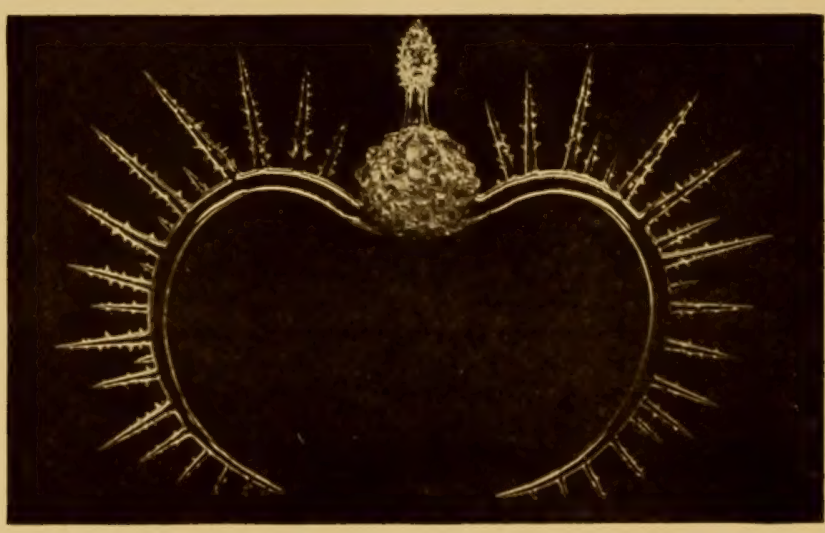

"Like Collections of Crown Jewels are the Cases of Fragile, Crystalline Sea and Pond Forms" seek its model and specimen charts which, however complex, clearly tell what an atom is, an element, a mineral, a crystal. ... In three other great teaching halls, those of insect, marine and reptilian life, the originality and cleverness of the mechanical means used to illustrate fundamental principles of biology and evolution are especially striking.

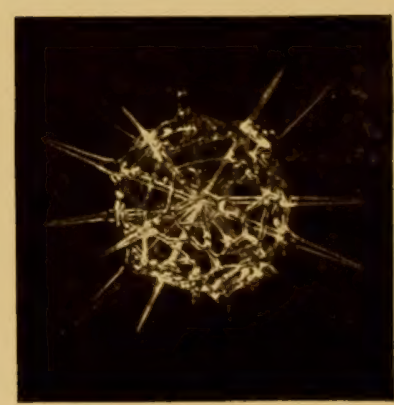

4 Page Forty lo- 


\section{PREPARATION}

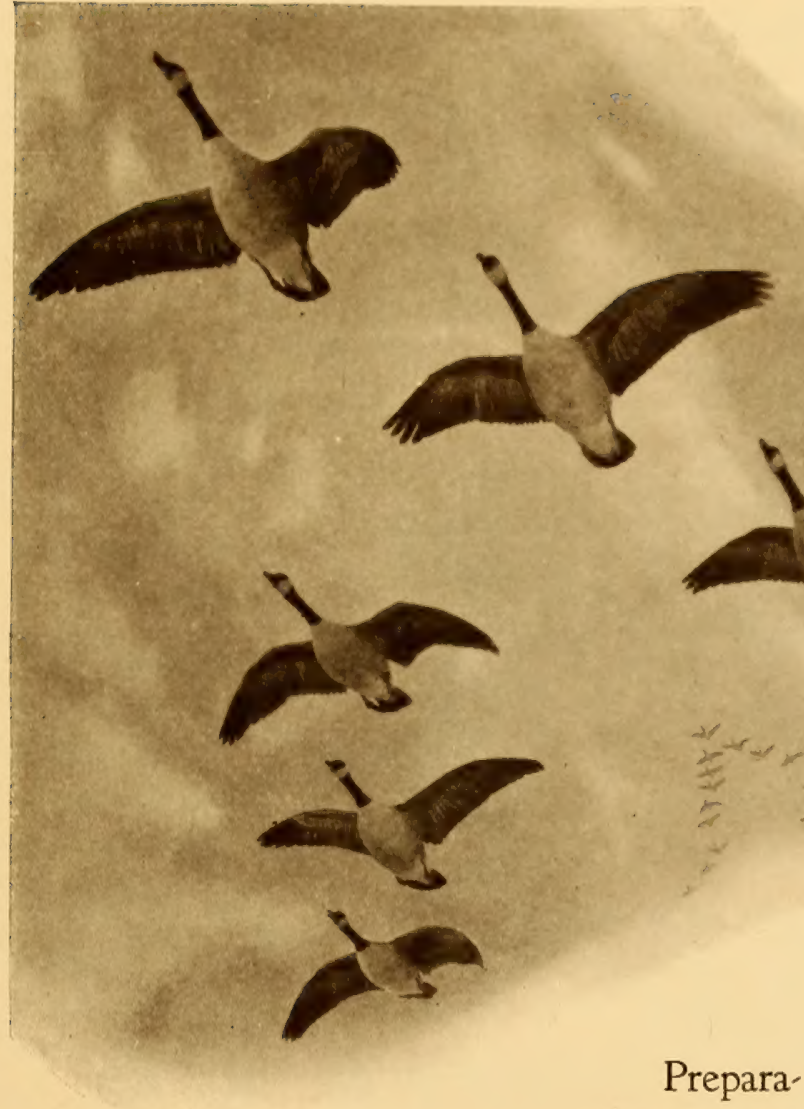

tion, as may

be gathered from all that has been said, has brought Museum exhibition out of the old, stiffly mounted single-specimen class into, first, the day of the habitat group, a section of the animal, or even inorganic world transported almost bodily from the field, and, second, the era of the unified exhibition hall, where every group, every exhibit, every decorative detail is made part of a whole - a veritable visual textbook.

It is notable that the first Museum hall to introduce the pioneer principle of habitat grouping also presaged the modern ideal of the hall as a total concept. The Hall of North American Birds, in its sweeping pictorial representation of the typical bird life of a continent, as shown in its chief climate zones and environments, lacks only the architectural unity and scope of design found in such halls as the new South Asiatic, African, and Oceanic.

This Hall of Ocean Life, it may be added, will represent in the Museum's current program of new construction a culmination in size-(indeed, it will be the largest museum hall in the world devoted to a single division of natural his tory) - and also a new peak in breadth

Canada Geese in Perpetual Migration Across the Dome of the Hall of Birds

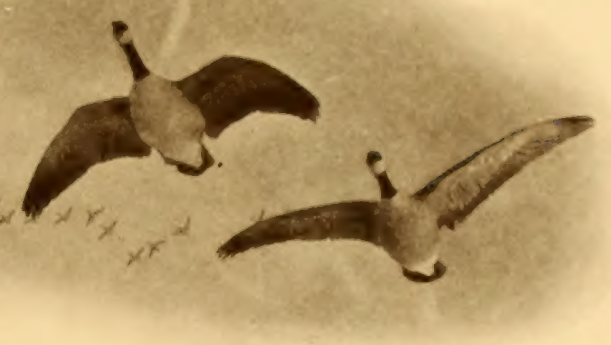

an

The Microscopic World of Pond Life-Enlarged a Million Times by the Skill of the Glassblower

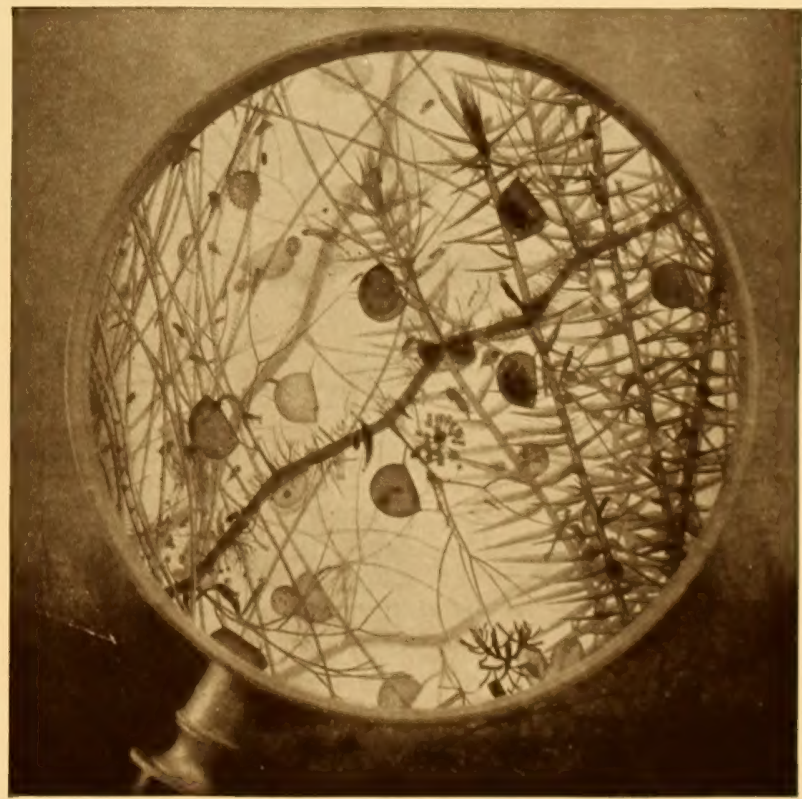




\section{PREPARATION}

and beauty of groups and murals used in combination.

These exhibition halls of the Museum, be it remembered, not only appeal to a sense of beauty through their perfect reproduction of Nature's forms, but they teach Nature's

Exhibits That Educate. From the Ravages of the Japanese Beetle to the Atomic Composition of a Crystal of Salt-There is Usually a Museum Group or Model to Tell the Story lessons to a million beholders a year. It is signifcance of subject matter, pleasurably introduced by beauty of illustration, which arrests public attention and entitles the Museum to public support as a university at large for all people - the interpreter of science to all comers.

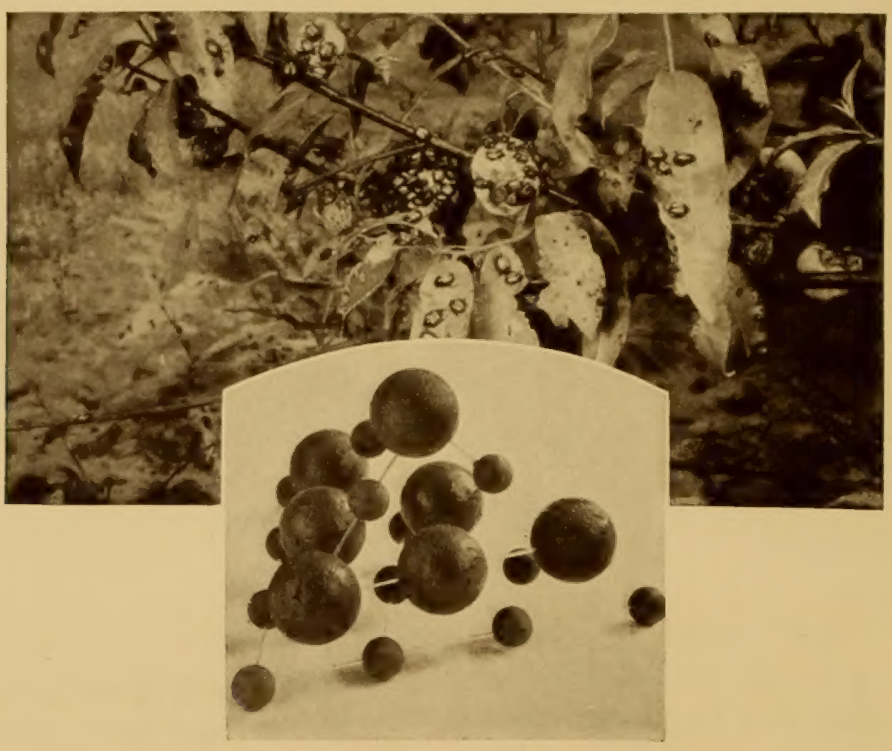




\section{EDUCATION}

$\mathrm{H}$

AVE YOU, the Museum in quires, a well suppressed desire to travel and study strange places? Then here, like open books, are Africa and India, Siberia and our own Southwest. ... Are you curious to know what revolutions of thought

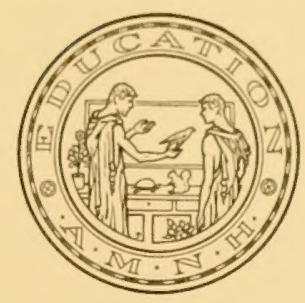
are occurring in the fields of biology, the inorganic sciences, anthropology? Then here are astronomy, entomology and bird lore, geology and marine life, fishes, reptiles and mammals, minerals and fossils ranging from sea shells to dinosaurs-here are demonstrated the principles of evolution, heredity, behavior - the atomic structure of matter - the mechanism of the human body. ... Special educational guides will take you to all sorts of places and open up all sorts of vistas, within the confines of one building. In fact, only by wearing a blindfold and stop. ping your ears could you be led through any section of this Museum without learning something surprising and

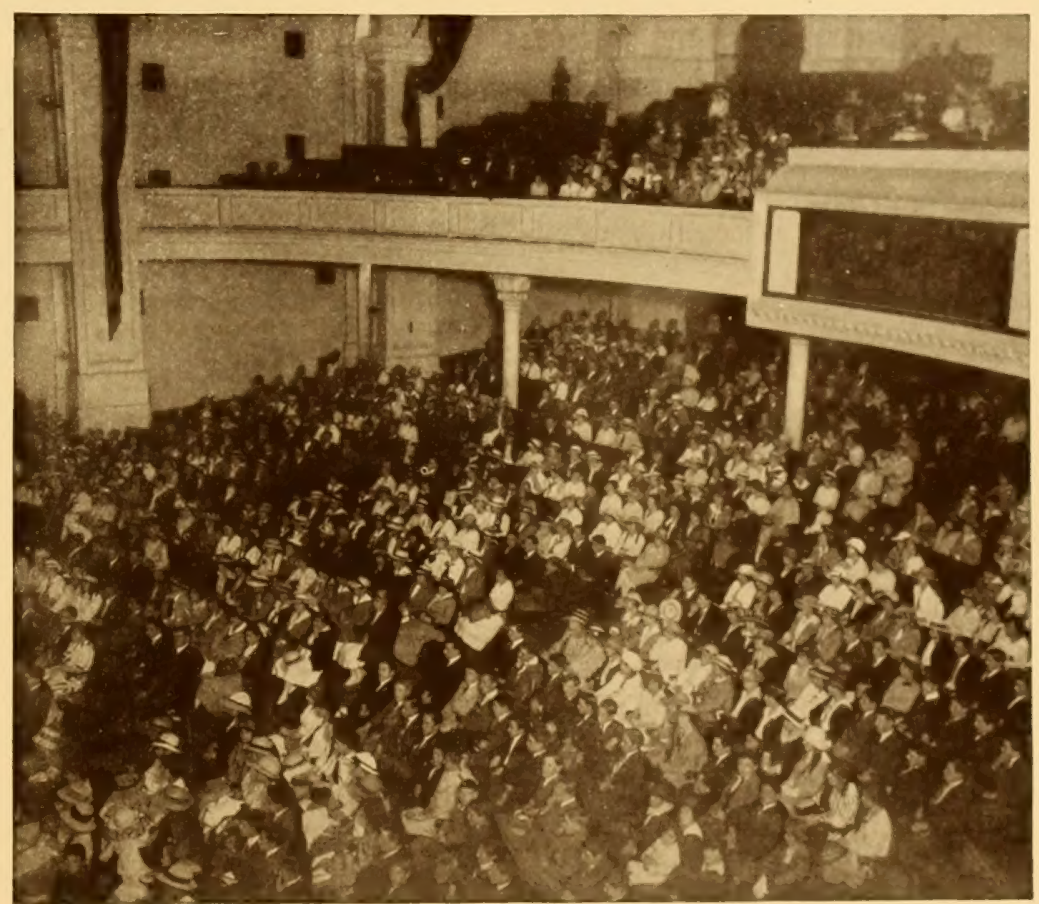

More than 200,000 People Annually Attend the Museum's Public Lectures and Motion Pictures thrilling - the most surprising, perhaps, that even the blind and deaf here hold classes in natural history!... Here are lectures, motion pictures of limitless variety and a natural history library with a staff ready to outline courses of reading on almost any live topic dealing with man or nature. ...

Are you merely a thwarted fisherman who never gets away from the office? The Zane Grey game fish collection and this year's record of rod and reel catches will brush you up on your subject. .. In default of hunting trips that remain pipe dreams, you owe yourself the vicarious adventure of big game hunting on every continent within Museum walls.

Perhaps your hobby is photography ... or collecting arrow heads, or butterflies . . . or weaving bas. kets? Some of the finest animal photographs in America are as sembled in a room of the department of mammals. .. Not a day passes that some fossil, Indian

A Page Forty-three Is 


\section{EDUCATION}

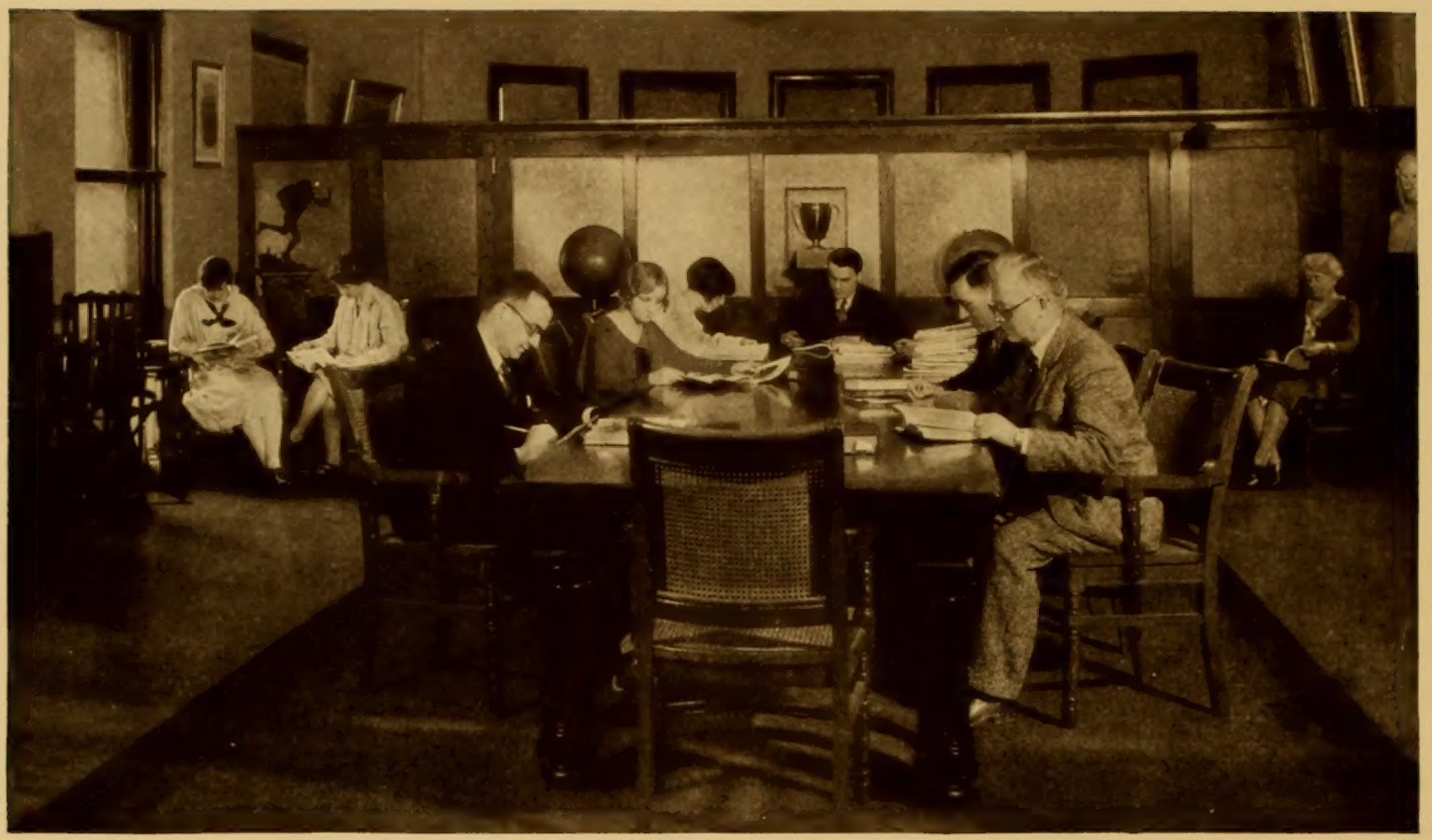

The Reading Room. Artists, Advertisers, Authors, Editors, Research Workers and Students-These and Countless Others Frequent the Museum Library

artifact, bird, plant, rock, insect, fish, reptile, or fragment of meteorite is not identified for somebody by a Museum official. . . . A work er, amateur or professional, in pottery, metals, textiles, jewelry or basketry may copy the masterpieces of Inca, Maya, Aztec, and North American cultures. He may study the unsurpassed weaving techniques of Peruvian cloths and of baskets that have given a name to an early, little-known people of our United States - the Basket Makers of perhaps 2000 B.C. From tombs millennial in age, these relics have emerged with colors and designs as
A Million Votaries a Year Seek This Tem. ple of Science. Contacts with Students of Schools, Colleges and Universities Num. ber More than 12,000,000 Annually copies or adaptations from the originals.

Some years ago, when the primitive in. dustrial and fine arts of North, Central and South America, as well as other parts of the world, were even less known and understood by us than now, the Museum, in cooperation with twenty-six industrial firms, held an epoch-making joint exposition of ancient and applied art, filling three halls converted for the pur pose. Textile manufacturers, furriers, designers of costumes and fabrics, dealers in art objects and women's wear participated. Primitive looms and modern power looms fresh and clear as those in shop windows today - shop windows, be it added, full of were shown in actual operation. Artists, craftsmen and laymen came by hundreds to

ol Page Forty-four b- 


\section{EDUCATION}

note and observe. This pioneer museum " $\mathrm{Ex}$ " hibition of Industrial Art in Textiles and and photographic department and haunting the offices of curators in search of information. A Costumes" had as its avowed object "creating a national art" drawn mainly from designs and techniques native to the Western Hemisphere. Its success is believed to have exerted an influence not only on contemporary craftsmanship but on the subsequent policies of at least two large art museums of Greater New York in making some of their store of material much more available to industry. ... .

Artists, sculptors, Indian painters, illustrators, advertising men, technical and magazine editors, writers, re-

Art Students and Workers, Amateur and Professional, in Pottery, Metals, Textiles, Jewelry and Basketry Come Daily to Copy the Masterpieces of Inca, Maya, Aztec and North American Cultures

search workers and students - these are but a few of the specialists frequenting the Library four persons collections.

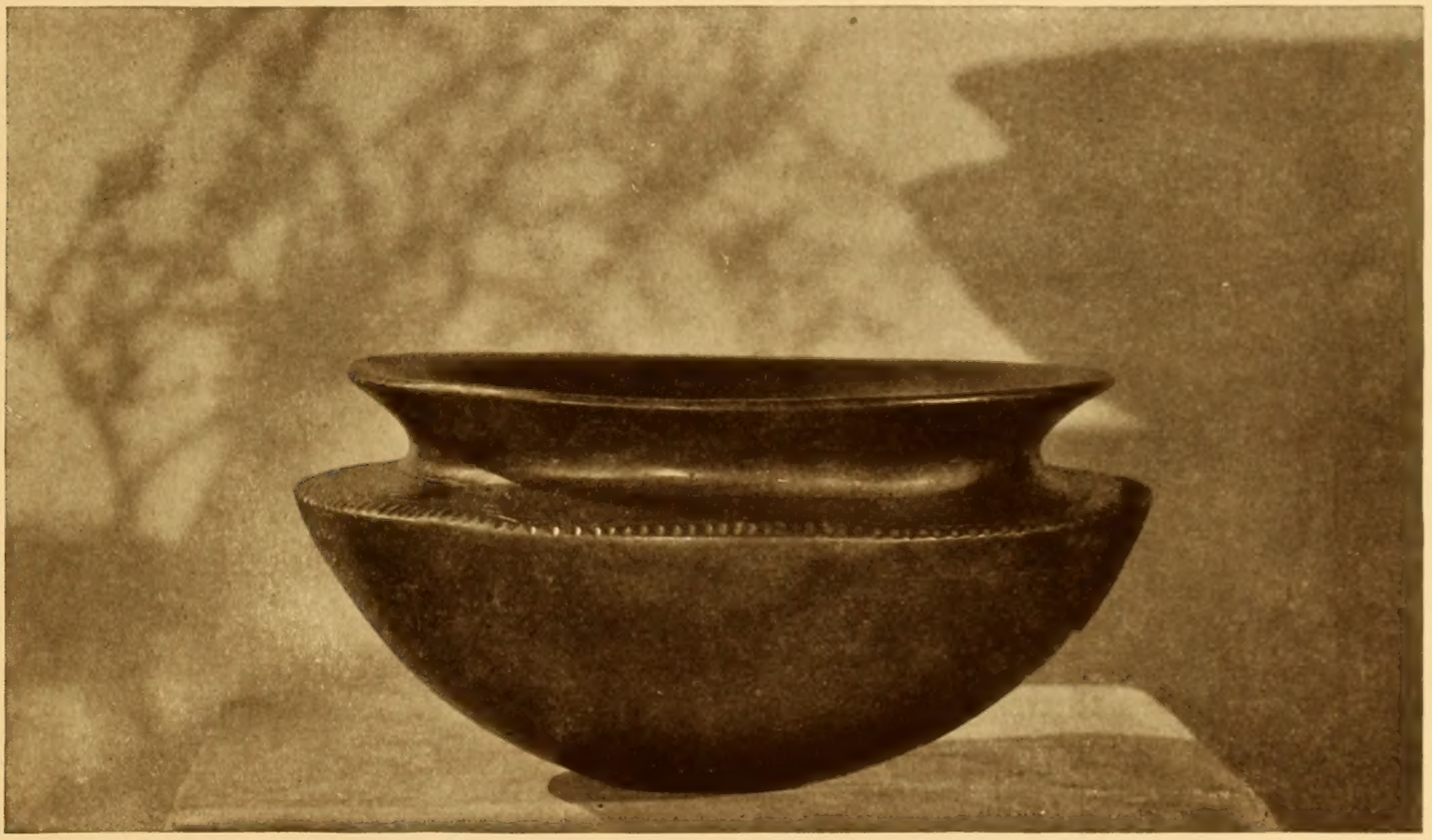

$\Rightarrow$ Page forty five | 


\section{EDUCATION}

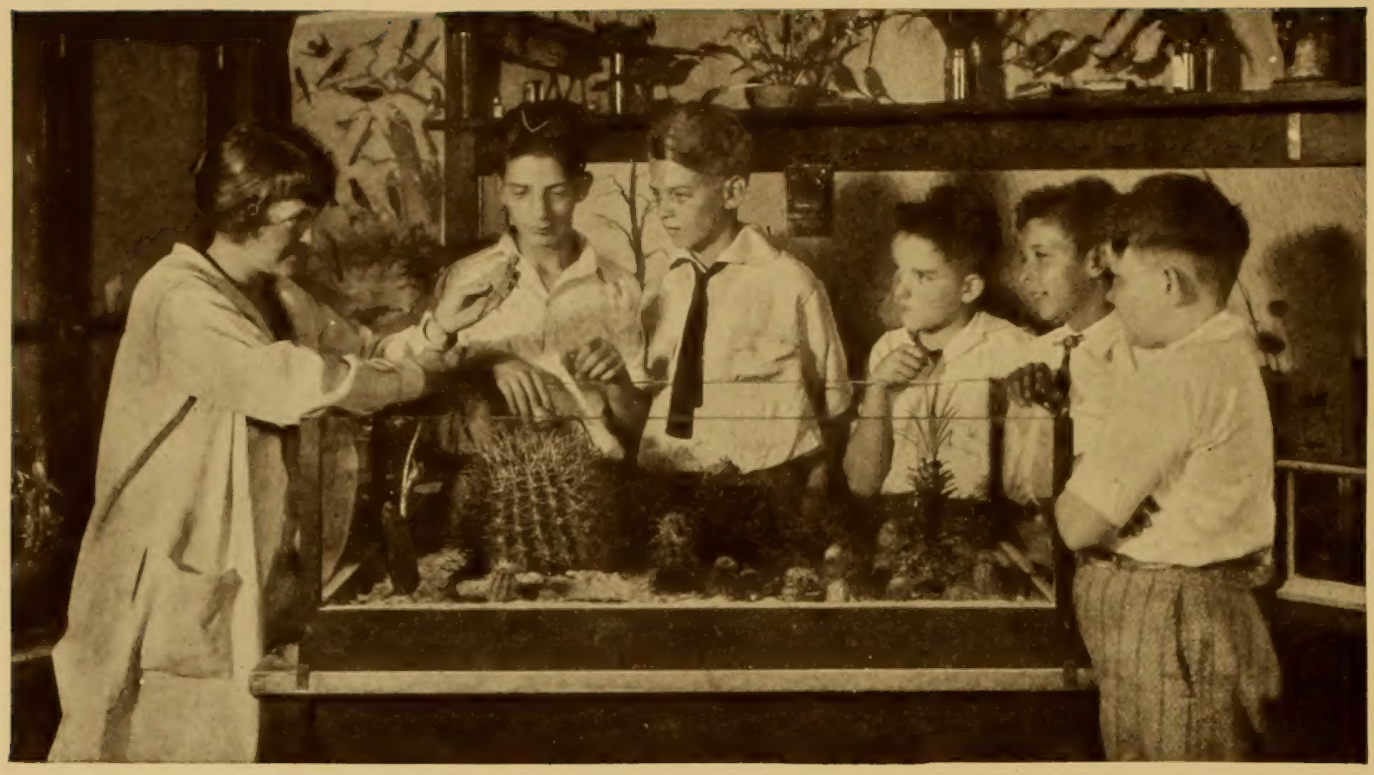

The School Na.

ture League

Room, a Model for Public Schools, is a Zoo-Museum in Itself

cupy the remainder of his life, was start ed on the road to travel and training and encouraged to become an ardent amateur entomologist.

It was in connection

Out of contacts with curators sparks are struck in many sorts of people. There is the young Russian boy, frequently found behind scenes, who has spent half of his two years in this country collecting and classifying beetles under the wing of the insect department. To him the $\mathrm{Mu}$ seum that has helped him epitomizes America. Judg, ing by the excellence of his work, he may become a good naturalist. ... . A retired doctor, desirous of a pursuit to ocon

This Way to the Museum's Nature Trails and Trail side Museum at Bear Mountain!

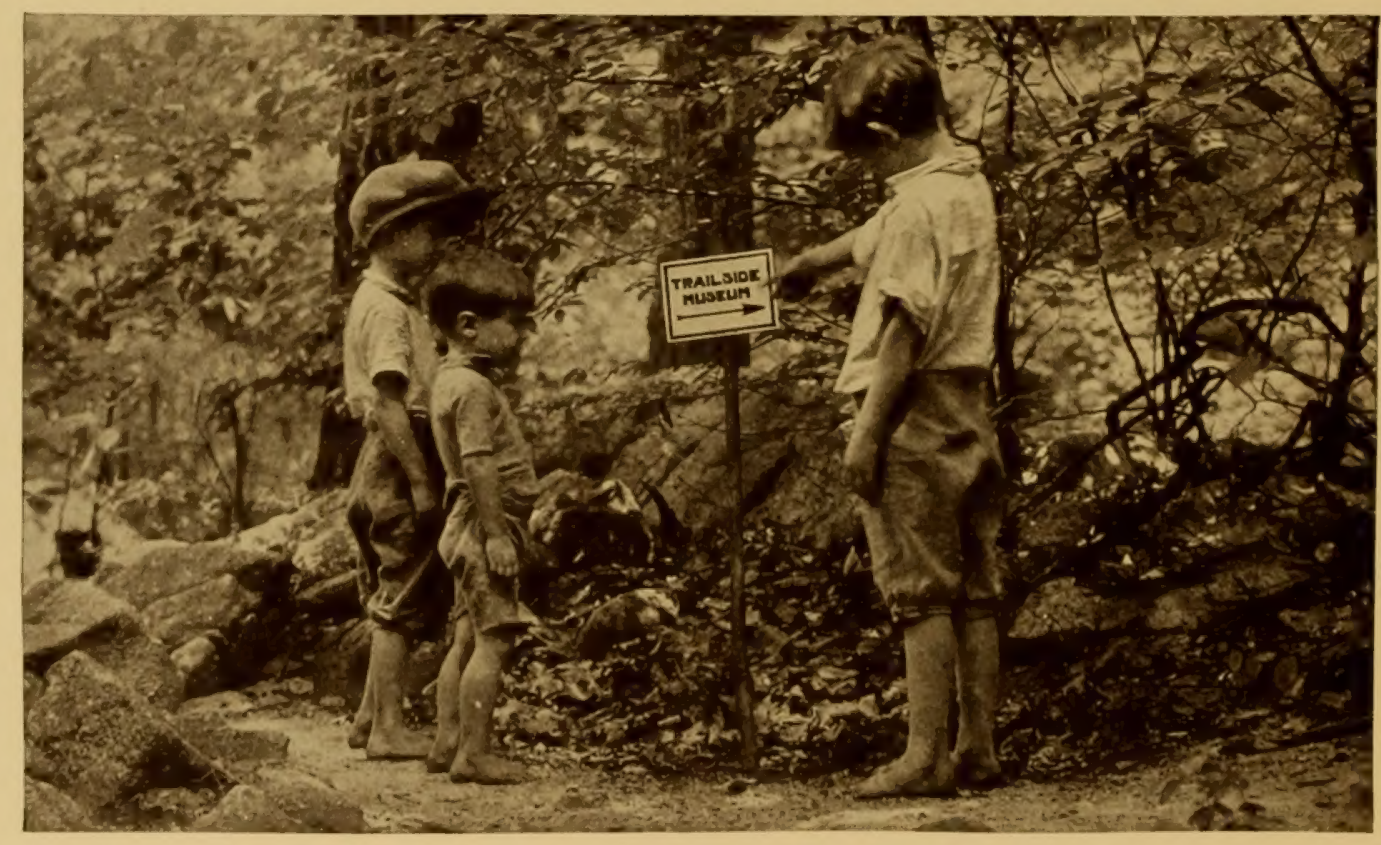

with an insect experiment station that the famous Nature Trails idea, which has now spread all over this country and abroad, was first crystallized by a Museum curator. One hundred and eighty-six thousand people last year visited the American Museum's Nature 


\section{EDUCATION}

What is a Mineral? These Chil. dren Are Finding Out oro

Trails-botanical, zoological, geological and historical and its Trailside Museum at Bear Mountain in the Palisades Interstate Park. In this center for tourists and

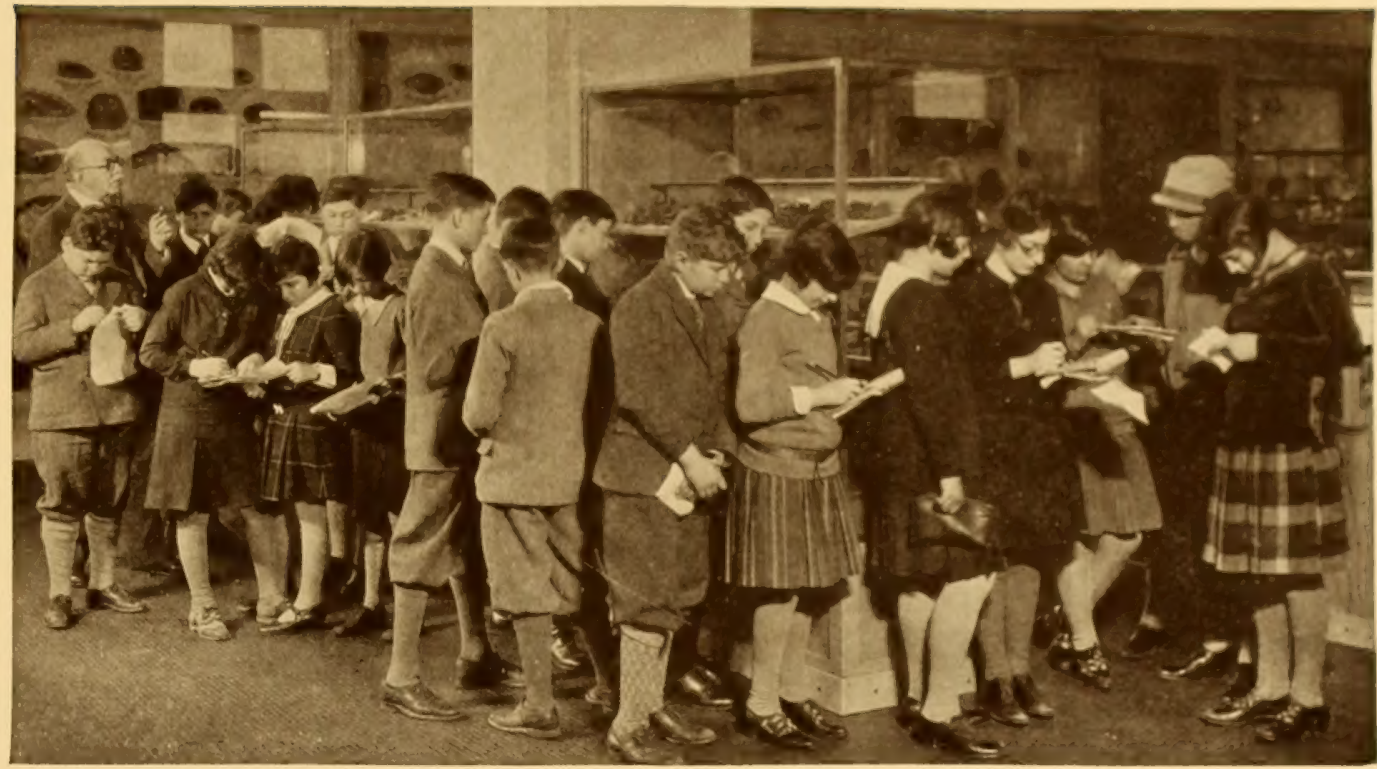
summer camps, children and adults make a holiday of learning the structure of rocks and the habits of plants and animals by seeing them in relation to their environment.

The astronomy department, one of the $\mathrm{Mu}$ seum's youngest, has made in five years' time

an astonishing record in organizing public interest in the subject. Two large associations, one of adult amateurs numbering a thousand members and one of young people numbering sixteen hundred, have, through department initiative, been formed to meet at the Museum and pursue,

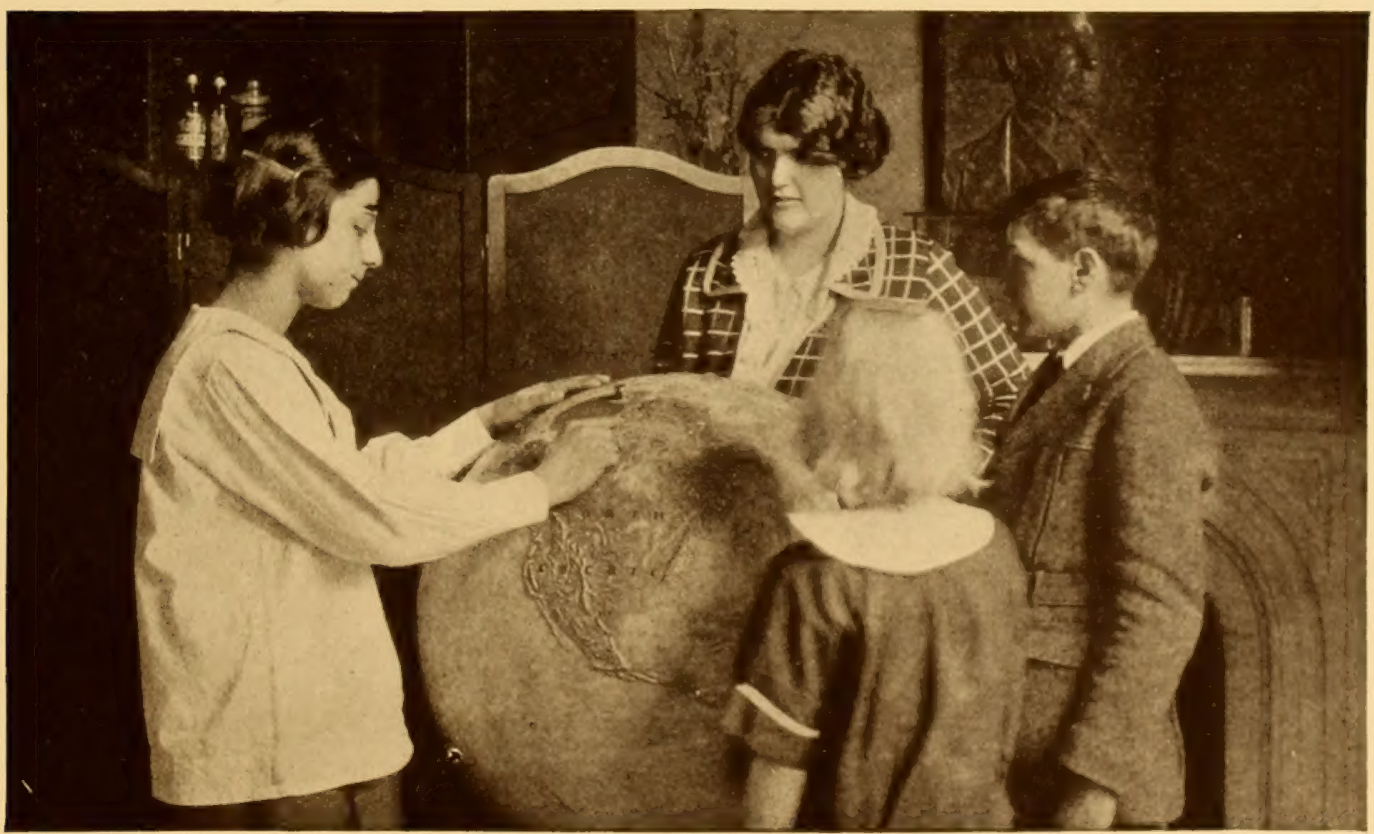
respectively, lecture courses given by eminent astronomers and group instruction under the de. partment of education. ... Museum astronomy, housed in

No

Impressions of the Earth

Blind Children and Sight Conservation Groups Are Taught at the Museum

-4 Page Fortyoseven ] 


\section{EDUCATION}

makeshift quarters and struggling to achieve a hall of its own, yet presents one of the most instructive and beautiful of exhibits, in addition to the stirring spectacle of youngsters making telescopes and star charts, conducting their own scientific jour. nal and club meetings, in an enthusiasm for study of our uni. verse not sur. passed by their older colleagues.

A wider audience than can be reached by any single de. partment of the Museum is secured by its publications, scientific and popular. These are, in the first place, the Bul-

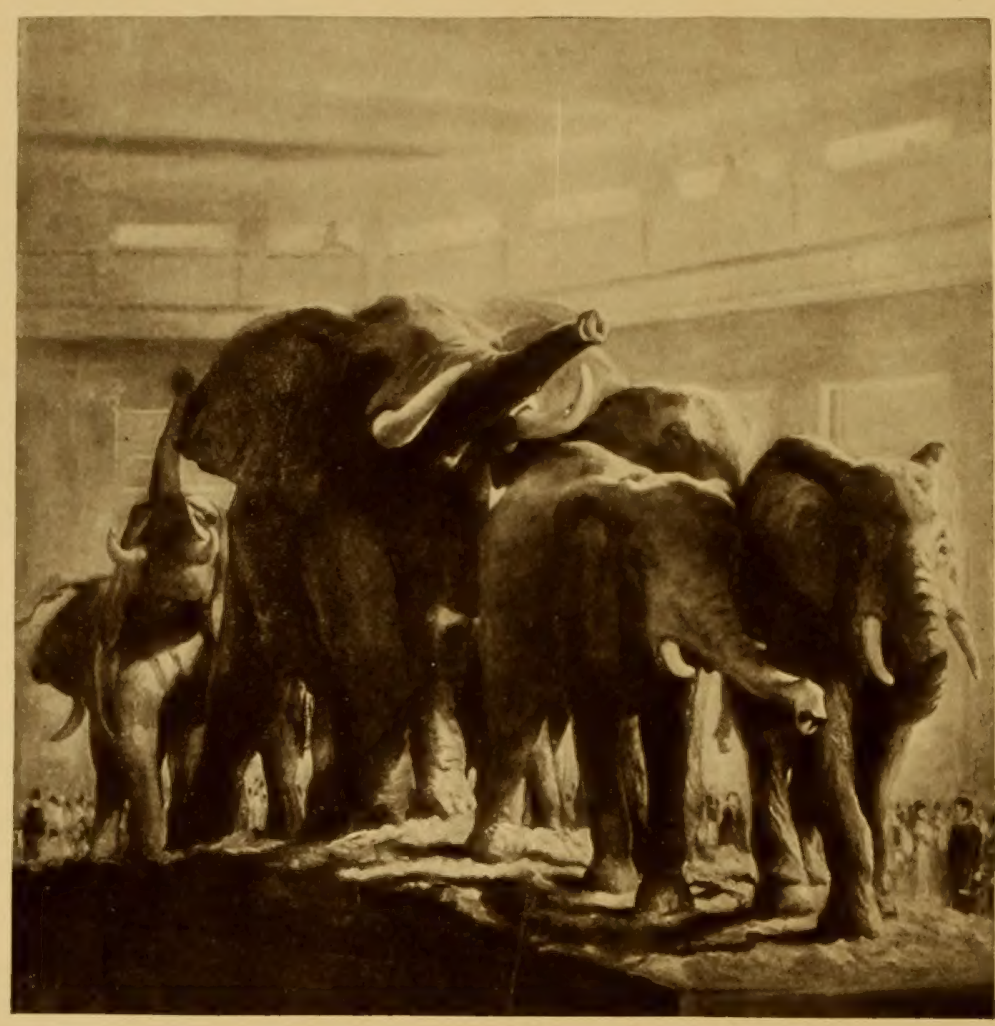

A Cover Subject from "Natural History," the Museum Magazine handbooks are used as text books by colleges and universities. In addition, there is no way of estimating what has been the influence upon the trend of public interest here and abroad of the thousands of copies of text books, reference works and popular writings of American Museum curators.

Declares the President of the Museum; "It is not enough for scientists to know; it is im. portant that people should know." Hence, though he has spent a lifetime in the produc tion of monumental scientific worksone of which required twenty-nine years for completion of research and publication-we find Henry Fairfield Osborn's "Men of the Old Stone Age" (in its "thirteenth printing, new and popular edition") listed among the best non-fiction sellers of its year. While preparing his major contributions to technical science, which have been based upon and have sum. marized Museum research, he has found time to become one of the foremost interpreters of scientific thought to the man in the street. . . . Theodore Roosevelt thus evaluated his work: "His exhaustive and many-sided knowledge, his 


\section{EDUCATION}

long scientific training, his natural insight, and his singularly just and fair temper, enable him to give us the first full, clear and critical presentation and interpretation of all that has been discovered and soundly determined since Darwin wrote "The Descent of Man.' "'

Who shall say that this is not education in its broadest sense?

Education is too commonly considered a prerogative of the young. The average notion seems to be that aside from spare-moment reading and an occasional lecture or concert, we have time only to make a living or manage a house, play a little golf or bridge or both, and educate our children. Unlike them, we have had our chance at an education; for us it is all over and done with.

To which the Museum offers an emphatic No.... Here is a place where without

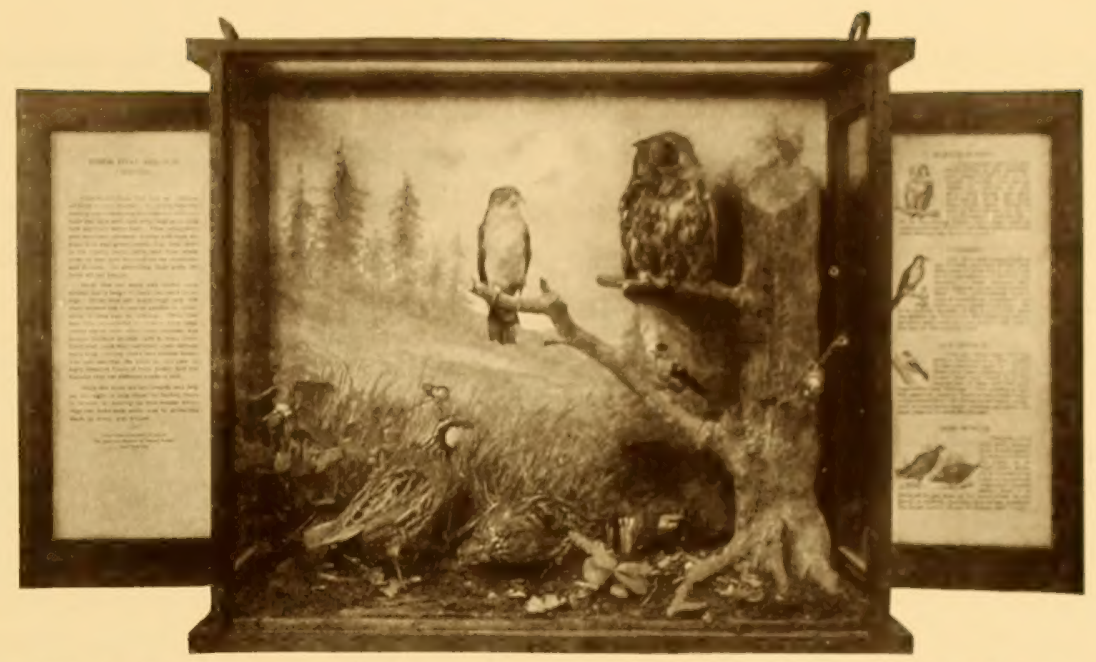

"Birds Useful to Man," One of the Museum's Circulating School Nature Study Collections

expense to you and in your spare time the essentials of a current education may be hadand pleasurably.

In its specific sense, education in the $\mathrm{Mu}$ seum is divided between the general public, teachers and higher students, and the pupils of elementary and high schools. The thirteen

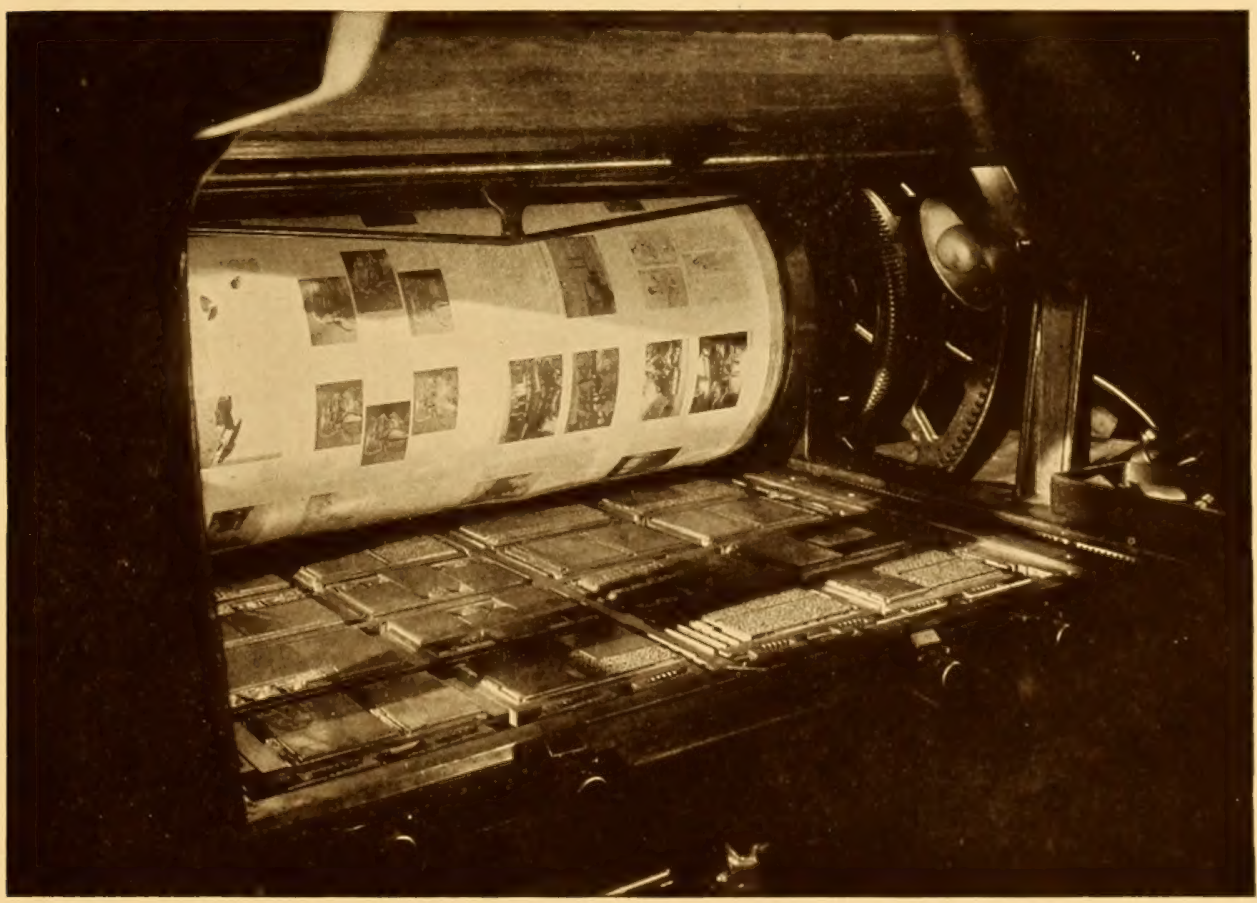
universities and colleges which use the Museum in some way as an extension field for the work of graduate and undergraduate studentsofferinstances of such close coopera. tion as that between Columbia University and the department of comparative anatomy, in which the curator, holding a chair in the University, gives three on

A Museum Press

Publications, Technical and Pop. ular, Give Worldwide Distribu. tion to Museum Exploration and Research 


\section{EDUCATION}

graduate courses at the Museum, where all the research by $\mathrm{Ph} . \mathrm{D}$. candidates is done on Museum material. . . Expansion of special work with college and university students, using the exhibition halls and study collections of the Museum, is now a definite project which depends upon the securing of adequate endowment. . . . These study collections, be it said, out of sight of the visitor while available to the student, are like the hidden portion of the iceberg - nine-tenths submerged and only one-tenth on exhibition.

$\mathrm{E}^{\mathrm{D}}$ DUCATIONAL service to the public schools of Greater New York was begun in 1880 by Albert S. Bickmore, superintendent of the Museum, one of its founders, and first curator of a department of education officially established in 1884. First under State and subsequently under City auspices, the department has from the beginning served the City's educational system.

This work, inaugurated for the instruction of teachers, has, under its present curator-in-chief, who is also director of the Museum, expanded enormously to include the million children in more than six hundred schools of the City.

"It is obvious," says the curator-in-chief,"that through its department of education the Museum comes in contact with greater numbers than through any other channel, because of the variety and extent of its school service. It would be impossible to over-estimate its value to the thousands of city children who have little opportunity to see the great outof-doors. The country dweller can hardly real- ize the restricted environment of many city chil dren. Their knowledge of Nature is limited to the dog, the cat, and perhaps the horse. The vegetable market and pushcart represent their acquaintance with growing things. ..."

Multiply that city child by a million and at once grant the validity of the plea of the Museum's educational department for more money for duplicate lantern slides and study collections - photographs and photographersmotion picture films for classroom showing guides and lecturers to handle the hordes of children thronging the Museum and its auditorium and lecture halls.

Education, as the Museum conceives it, means giving an individual, whether child, college student, teacher or layman, a rounded conception of the Cosmos and his place in it. The difficulty is that cosmic conceptions do not stand still for us - they grow by accretion of newly discovered fact. The discoveries and conquests of natural science have brought about such developments in thought during the past

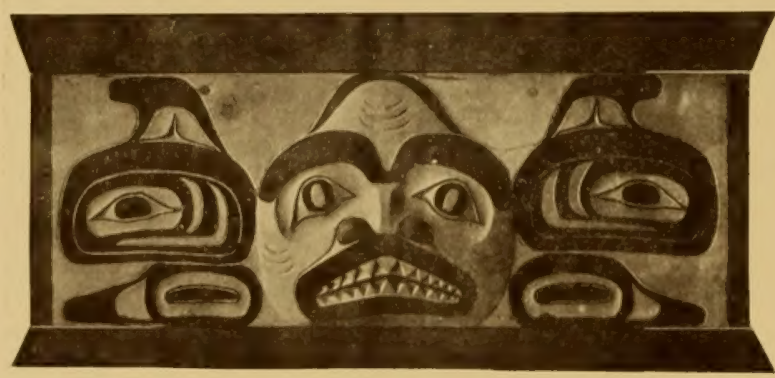
century that they should be known to all persons of liberal culture. To continue to bring new facts and concepts to the public is one of the Museum's responsibilities. The hitch in the program is that the de. mands on the general funds are such that ex. hibits of late discoveries and demonstrations of research results must depend on haphazard out side financing or wait indefinitely. Meanwhile the Museum's whole educational policy suffers setbacks from the simple lack of that common. place commodity - money. 


\section{PLANS, PROJECTS AND \\ PIPE DREAMS}

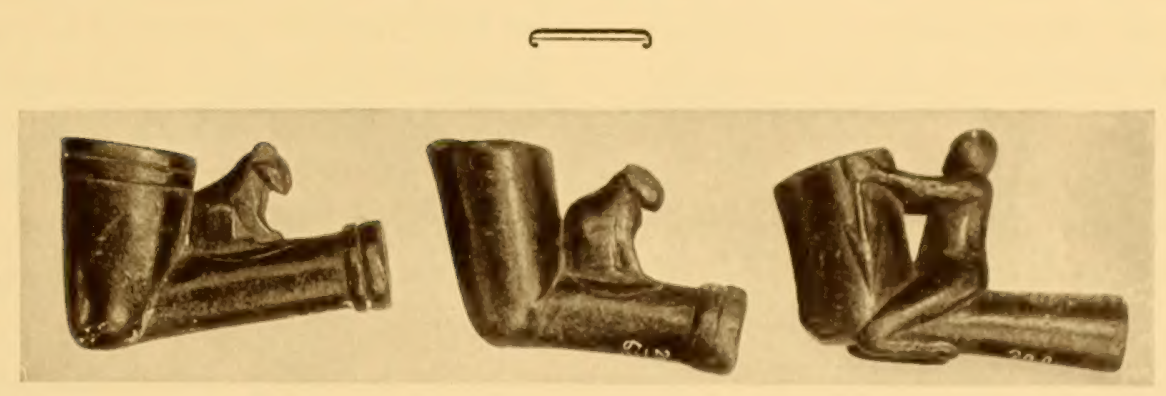

W HY SHOULD the work of a great educational institution like the American Museum of Natural History be hobbled and handicapped by a constant concern for the wherewithal with which to make even ordinary progress?

The only permanent answer is endowment-more endowment than the Museum has.

Endowment means a stable foundation, not only for the daily work of departments at present severely hampered, but also for those plans and projects now impossible except as curators' pipe dreams.

Not since the war has Museum income been sufficient to meet rising costs and spare enough besides for any but the most indispensable department work in field and laboratory.

For example:

The geology department urgently needs funds for displaying the economic phases of its subject, with exhibits of mining methods and the uses of coal, oil, gas, salt, sulphur, lead, zinc and mineral products in general.

The department of mammals has, to date, been unable to renovate an old hall and thus relieve an unfairness to our own North American mammals, many nearing extinction, by giving them as adequate and beautiful display as that for the mammals of Africa, India and other seemingly more glamorous lands.

The bird department, in common with most of the others, has been waiting long for additional field research workers, for assistants to follow up current research on material in hand, and for money to carry the results of this research through the Museum press. "More research workers" is also the urgent plea of the department of experimental biology. . . .

In wall cases flanking some of the related anthropological displays is a partly finished group of ingenious exhibits in comparative anatomy which there is no money to complete. Charts of the models proposed show, for instance, Man as an Engine, Man as a Physical and Chemical Laboratory, The Human Face, from Fish to Man.

A laboratory for the study of live insects is the need of the department of insect life, whose present exhibits of live insects give so much added interest to its ordered collections, arranged in veritable textbook sequence.

A field laboratory for marine research in one of the established biological experiment stations, where the Museum can be continuously represented, is the annual request - as yet impossible of fulfilment - of the department of marine life. As for the fish department, there is a 


\section{PLANS, PROJECTS AND PIPE DREAMS}

great open space outside its dark room of luminescent deep sea forms, which, it is hoped, may be filled with an exhibit of Hawaiian fishes; while elsewhere a section awaits an up-to-theminute exhibit on aërodynamics - a comparative study of the motions of airplanes and fly. ing fish.

Continuous motion picture machines which aspire to tell visually the stories and lessons of habitat groups and teaching exhibits - these, and funds to form a Junior Naturalists' Club, make up the hopeful requisition of the department of education upon a too-depleted Museum treasury.

Pipe dreams, perhaps, but how well worth the dreaming! . . . An unplumbed treasure vault for science is a certain island cave in the Mediterranean - shelter for thousands of years of successive peoples, who have left in pottery and in metal and stone implements a stratified record of man's slow ascent from a time believed to be palaeolithic. It would cost little to excavate this cave floor, layer by layer, with the glorified vacuum cleaner which one practical-minded curator would take to the site. But here, too, the lack of a few thousand dollars frustrates the develop. ment of what might prove to be a more important continuous register of the human race than any yet uncovered.

To set up the universe in the Museum is the pet desire of another curator! However, that desire may be expressed in one practical word, planetarium. Germany has many,

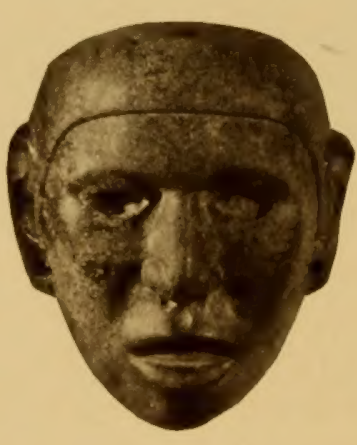
Chicago one, Philadelphia one - each the gift of a philanthropist. The Museum's young astronomy department wants one for the millions living in or visiting New York. This new in. strument of education, virtually without parallel in any branch of learning, is an almost incred. ible invention-a sublimated stereopticon which projects luminously upon a huge dome, for hundreds of spectators at a time, a moving picture of the heavens. By its use the astronom. ical bodies can be seen revolving in their orbits at an accelerated pace, or halted in the relative positions they have assumed, or will assume, at any given moment from the time of Joshua up to the most remote future day!

In cramped glass cases in the department of Mexican and Central American archaeology lie, jumbled together for lack of space, exquisite Aztec, Mayan and other potteries, sculptures and carvings, any one of which, in a proper in dividual setting, would bring forth gasps of appreciation. Such settings - forming a true shrine to the early cultures of the New World - are planned against a day of plenty. Meanwhile, in the cruelly confining casesonly one of which, by way of demonstration, shows what might be done with a little taste and money - lie hundreds of pieces of rare pottery, hundreds of small, expressive terra cotta figurines of children and adults grave and jocose, wistful and grotesque, fairly pleading for the notice and ap. preciation due them. They are like little voices crying out from the clay of the past to heedless modern Americans to pause and hear what they have to tell of our own native civilizations. ... .

Why should such eminently sound plans and projects remain pipe dreams? There are so many of them that command attention - at least ten to every curator. An endowment great enough to mother them all is the basic need of the American Museum of Natural History. 


\section{WHY TEN MILLION DOLLARS?}

$A^{\mathrm{L}}$ THOUGH the building needs of the American Museum are being splendidly met by City and State, annual public support of the Museum continues to fall far short of even the routine requirements. For example, only heavy emergency contributions by Trustees have prevented discharge of many employees. Yet the department budgets thus temporarily bal. anced serve to cover little more than ordinary maintenance. They have been insufficient to prevent a sharp curtailment of scientific work - the very being of the Museum, the basis of its prestige and of its unique service.

Exploration, research, publication, educational work, the Library - all are suffering for want of adequate financial support to overcome the doubling or trebling of all costs since 1914. Departments are short-handed, their activities at reduced pace. Lost through death, eminent staff scientists can not be replaced because funds are lacking to secure qualified successors. . . Everywhere is evidence of the

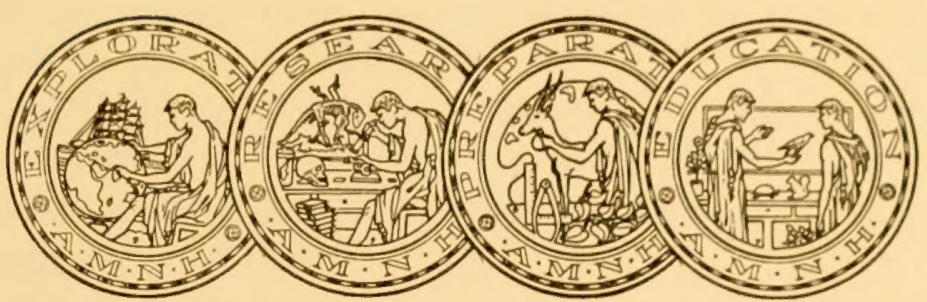

discouraging hand of retrenchment laid upon Museum pro gress, for, even with the close budgeting of a conspicuously able financial department - even with the most careful administrative supervisionwhen overhead ex penses are met, there is little remaining.

Become the particu lar pride of the people of Greater New York and a household word all over the globe, the American Museum, if it is to continue its progressive record of achievement, thus far unbroken since its founding, should have no less an increase in annual income than $\$ 500,000$. This would be assured by the Sixtieth Anniversary Endowment Fund of $\$ 10,000,000$, completion of which is the institution's greatest urgency.

Throughout its long career the American Museum has always gone forward.

Only now, in the beginning of its seventh decade, does it find current projects and future development menaced.

The plain and positive remedy is the generous subscription of this capital fund. 


\section{PROPOSED APPORTIONMENT OF THE SIXTIETH ANNIVERSARY ENDOWMENT FUND}

Research: For permanent support of exploration, research and publication now largely dependent on special gifts. .............

Books: $\quad$ For the purchase of books new and old for the Library. Books are essential tools for carrying on all researches. .............

$\$ 2,000,000$

300,000

Staff: $\quad$ For additional assistants for curators, including highly trained productive research workers, so that more curatorial time may be given to research and publication.................

Salaries: For raising the standard of all staff salaries to university and college grades, making them commensurate with the training, skill and ability of scientific workers..................

Exhibition

For the modernizing of old halls and the proper educational equip. Halls: ment of all halls (fifty, including those to be established in the

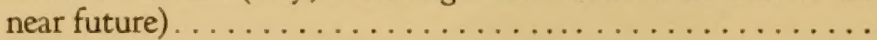

Education: For intensive high school, college and university education in the laboratories and exhibition halls of the Museum and for the extension of service to the secondary schools............

Exhibitions: For the preparation of existing exhibitions and collections to render the highest educational service to students and to the visiting public

Reserve: Reserved for the development of future plans in connection with the addition of four new building sections to the institution.....

Total . . . . . . . . . . . . . . . . . . . . . . .

$1,700,000$

$\$ 10,000,000$

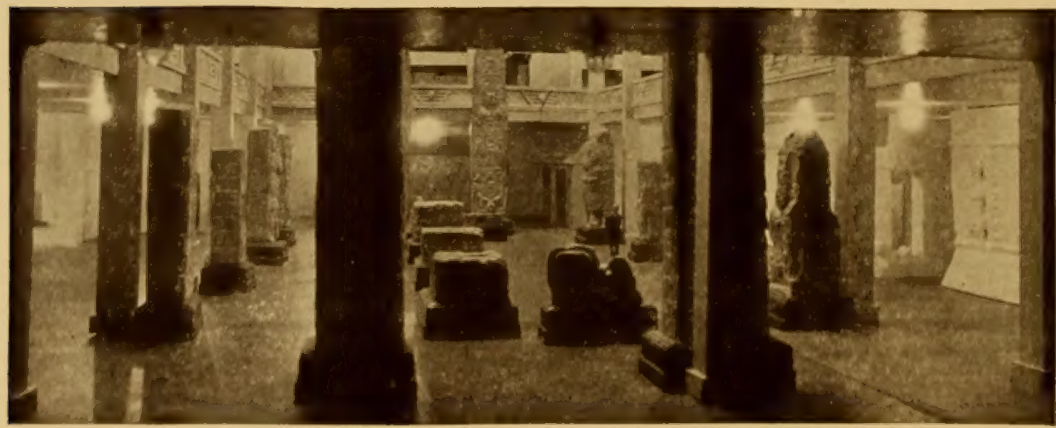




\section{THE AMERICAN MUSEUM OF NATURAL HISTORY}

\author{
First Vice-President \\ George F. Baker
}

George F. Baker

George F. Baker, Jr.

George T. Bowdoin

Frederick F. Brewster

Douglas Burden

Frederick Trubee Davison

Cleveland Earl Dodge

Lincoln Ellsworth

Childs Frick

Madison Grant

Hon. Charles W. Berry

Comptroller. City of New York

\section{OFFICERS}

President

Henry Fairfield Osborn

\author{
Second Vice-President \\ J. P. Morgan
}

Treasurer

James H. Perkins

\section{BOARD OF TRUSTEES}

Chauncey J. Hamlin

Clarence L. Hay

Archer M. Huntington

Oliver G. Jennings

Roswell Miller

Ogden L. Mills

J. P. Morgan

Junius S. Morgan, Jr.

A. Perry Osborn

\section{EX-OFFICIO}

Hon. James J. Walker

Mayor, City of New York
Henry Fairfield Osborn

James H. Perkins

Daniel E. Pomeroy

George D. Pratt

A. Hamilton Rice

Kermit Roosevelt

Henry W. Sage

Leonard C. Sanford

William K. Vanderbilt

Felix M. Warburg

Hon. Walter R. Herrick

Commissioner of Parks

\section{TRUSTEE COMMITTEE ON NEW ENDOWMENT}

General Chairman-Henry Fairfield Osborn

Treasurer-James H. Perkins

George T. Bowdoin

Douglas Burden

Cleveland E. Dodge

Childs Frick
Clarence L. Hay

Junius S. Morgan, Jr.

A. Perry Osborn

George H. Sherwood-Secretary of the Committee
Daniel E. Pomeroy

Henry W. Sage

Leonard C. Sanford

Felix M. Warburg 



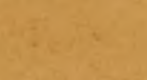

(3)

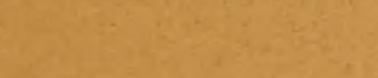

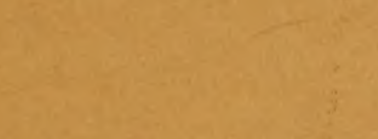

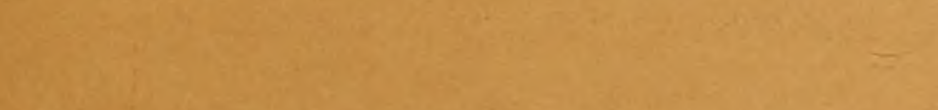




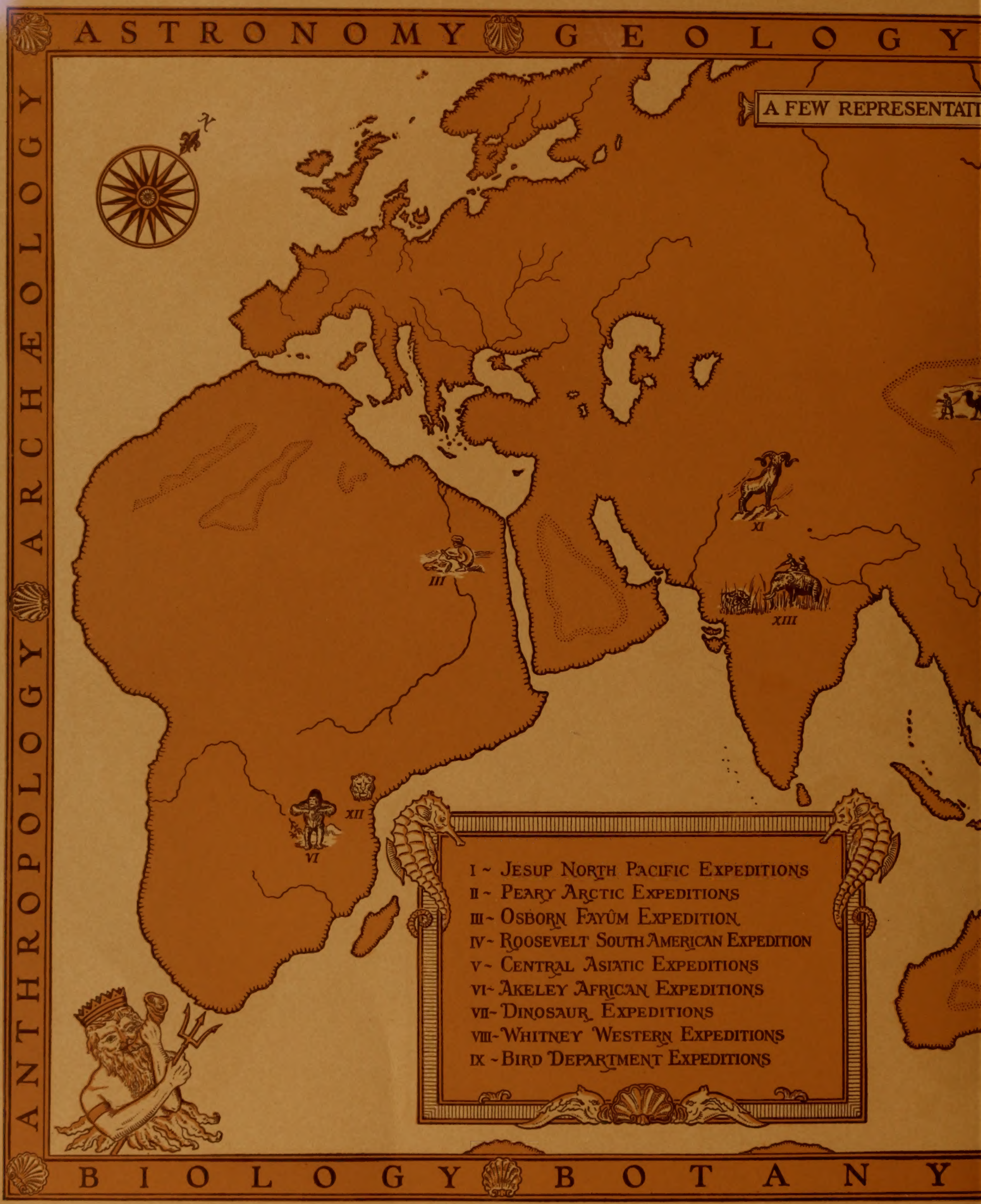


